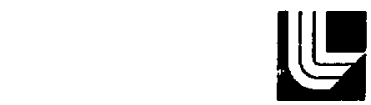

LAWRENCE L.IVERMORE LABORATORY

Universily of Callornia Livermore.California 94550

UCRL-52535

\title{
DETERMINATION OF A RADIOACTIVE WASTE CLASSIFICATION SYSEEM
}

\author{
J. J. Cohen \\ W. C. King
}

MS. datte: March 1978

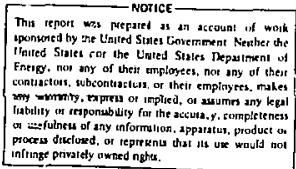


FORENORD

The U.S. Nuclear Regulatory Commission (NRC) has retained the University of California Lawrence Livermore Laboratory (LLL) to provide technical support for its Nuclear Waste Management Program. Development of a classification system for radioactive waste is part of this program.

This LLL project:

- Determined objectives for the required waste classification ihns system.

- Identified and evaluated relevant system paramsters.

- Developed a suitable format (classes of waste) for the system.

- Determined the interfaces between classes.

Work was done in two phases, largely with the assistance of subcontractors. Phase 1--through development of a system format--was done with help from Science Applications, Inc. (SAI), McLean, Virginia, from June through December 1976. Ford, Bacon \& Davis Utah, Inc., of Salt Lake City, Utah, helped with phase 2 from March through October 1977.

Technical advisory panels (TAP's) of experts from industry, government, and research institutions provided guidance during each phase. Members of the first TAP (Appendix A) met in Reston, Virginia, in August 1976, after which a revised working document was prepared. TAP members critigued the document at the second meeting in La Jolla, Calif., in October 1976. LLi published a. interim report ${ }^{1}$ based on the critiqued document.

This report summarizes the project's work and presents our rationale and conclusions. 
CONTENTS

For eword

List of Illustrations

List of Tables

Abbreviations

Abstract

Summary

Introduction

Development of a classification Format

Assessment of Waste Classification systems

Bases for Defining Waste Classes .

Criteria for Defining Waste Classes

Transuranic Wastes

Proposed Format and Guidelines for a

Waste Classification system

Establishing Interface Levels

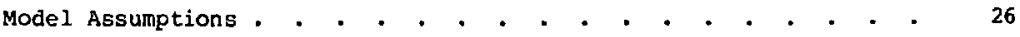

Dose Calculations : . . . . . . . . . . . . . . . . 29

Relative Hazarỏ Index Defined . . . . . . . . . . . . 34

Evaluation and Discussion of Results . . . . . . . . . . . . 35

Inhalation scenarios . . . . . . . . . . . . . . . . 36

Ingestion Scenarios . . . . . . . . . . . . . . . . 36

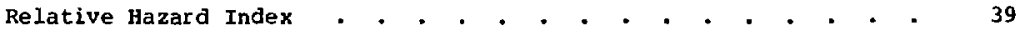

Cost-Benefit Analysis . . . . . . . . . . . . . . . . 41

References . . . . . . . . . . . . . . . . . . . . . 4 43 
APPENDIX A: Roster of Members and

Participants of the Phase 1 Technical

Advisory Panel . . . . . . . . . . . . . . . 45

APPENDIX B: Roster of Members and

Participants of the Phase 2 Technical

Advisory Panel . . . . . . . . . . . . . . . 47

APPENDIX C: Previously Proposed Radioactive-

Waste Classification Systems . . . . . . . . . . . 48

APPENDIX D: WC Systems Proposed By TAP Members _ • • • • • • • $\quad$. 74

APPENDIX E: Code of Federal Regulations . . . . . . . . . . . 9i)

APPENDIX F: Characteristics of Existing

Low Level Waste (LLW) Disposal Sites . . . . . . . . 96

APPENDIX G: Reference Containment Facility Details . . . . . . . 112

APPENDIX H: Calculations For Airborne Releases . . . . . . . . . Ils

APPENDIX I: Calcuiations for Waterborne Releases . • . • . . . . 126

APPENDIX J: Application of the Relative hazard Index (RHI)

Concept for Individual Nuclides and Mixtures . . . . . 146 


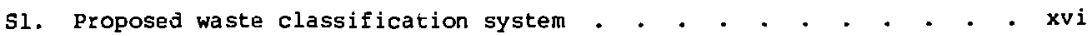

S2. Annual dose vs ${ }^{239} \mathrm{Pu}$ HLW/LLW interface

level for six analytical scenarios . . . . . . . . . . . . xvii

1. Process operations and wastes in the LWR fuel cycle ${ }^{2}$. . . . . 2

2. Considerations for applying waste disposal methods . . . . . 12

3. Schematic of proposed radioactive waste classification system . . 20

4. Schematic of reference containment facility . . . . . . . . . 25

5. Hunan exposure pathways consijerad . . . . . . . . . . . . 28

6. Effects of short-term inhalation $(500 \mathrm{pci} / \mathrm{d}$ for $30 \mathrm{~d})$ of. ${ }^{239}{ }^{\text {P!j oxide }}$. . . . . . . . . . . . . . . . . . . . . . 30

7. Dose resulting from continuous $50-y$ inhalation

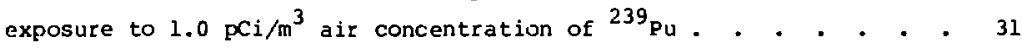

8. Annual individual dose vs $H L W / L L W$ interface concentrations for ${ }^{239} \mathrm{Pu}$ calculated for six exposure scenarios . . . . . . . . 35

9. Waste classification system in relative hazard index format . . . 40

io. Cost-benefit analysis results . . . . . . . . . . . . . . . 42

C.?. IAEA waste classification system . . . . . . . . . . . . . 51

C2. AIChE waste classification systen . • . • . • . . . • • . 56

C3. Gera's classification system based on duration of containment . . 57

C4. Gera's 1968 waste classification system . . - . . • . . . . 5B

C5. American National Standards Institute waste categories . . . . . 64

C6. AEC waste classification system . . . + . . . . . . . . . 67

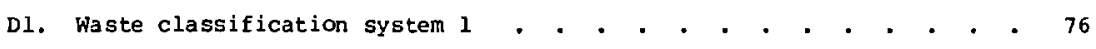

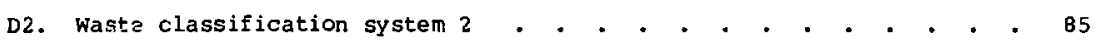

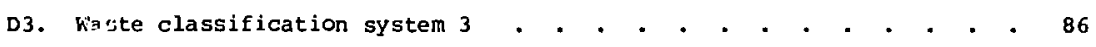

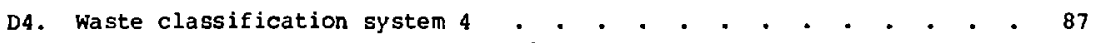

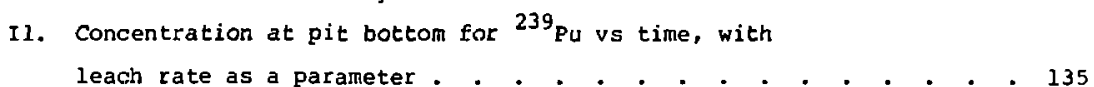

12. Concentration at aquifer outlet vs time with dispersion coefficient as a parameter for ${ }^{239} \mathrm{Pu}$. . . . . . . . . . . . 136

13. Concentration at aquifer outlet vs time for ${ }^{239} \mathrm{Pu}$ with boundary condition pulse length as a parameter . . . . . . • . 137

14. Effects of water volumetrlc flow rate in stream on maximun individual doses

I5. $\mathrm{Q}_{\mathrm{A}} / \mathrm{Q}_{\mathrm{B}}$ vs time for ${ }^{239} \mathrm{Pu}$ 


\section{LIST UF TABLES}

1. Euel cycle wastes lirom generation of 1000 MWe-y by LWR's using mixed oxjde (U-Puj fuels . . • . . . . . . . . . . 3

2. Postfission wastes per GWe-y expected from the LWR fuel cycle . . 4

3. Survey of existing low-level waste disposal facilities . . . . • 22

4. Calculated concentrations of radionuclides in LWK solid wastes shipked to commercial burial grounds. . . . . . . 23

5. Projected relative waste concentrations and volumes per GWe-y • 424

6. Reference containment facility parameters and values . • • • . 25

7. Nuclide-specific parameters and values . . . . . . . . . . 27

8. Organ doses for mixed 'JRU nuclides aged 6 mo and 100 y relative to ${ }^{239}{ }_{P_{11}}$ doses . . . . . . . . . . . . . 32

9. Single radionuclide HLW/LLW interface concentration values . . 37

c1. AIChE radioactive waste categor ies . . . . . . . . . . . . 54

C2. Categories of 1 iquid and gaseous wastes proposed by Gera (1968) . . . . • . • . . . . . . . . . . . 59

C3. Categories of solid wastes according to activity concentration and half-life proposed by Gera (1968) . . . . . . E0

C4. Categories of solid wastes according to radiation index proposed by Gera (1968) - . . . - . . . . . . . . 61

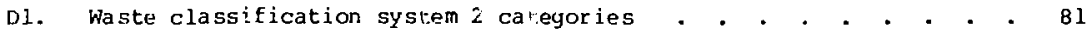

D2. Waste classification system 2 subrategories . . . . . . . . 83

D3. Waste classification system 2 symbols and mearings . • . . . . BA

F1. Capacities, covers, and water collection provisions at existing LLW sites . . . . . . . . . . . . . . . . 98

F2. Waste inventories at existing LWW sites . . . . . . . . . . 99

F3. Climatological parameters at existing LLw sites . . . . . . . 100

F4. Hydogeologic parameters at existing LLW sites . . . . . . . I0I

F5. Demographic data for existing LlW sites . . . . . . . . . 102

F6. Average concentration, $\mathrm{Ci} / \mathrm{m}^{3}$ of LLW buried at comercial sites, 1963 through 1976 . . . . . . . . 105

F7. Byproduct material buried at LLW sites from 1952 through 1976 • 106 
F8. Special nuclear materials (fissile materials)

buried at LLW sites . . . . . . . . . . . . . . . 107

F9. Source haterial (nonfissile uranium and thorium) buried at commercial sites . . . . . . . . . . . . . . 108

F10. Irventory of nuclides as buried at INEL . . . . . . . . . . 110

Gl. Cost factors for RCF . . . . . . . . . . . . . . . . . 114

Hl. Values of $I_{o}$ in $\mu C_{i}$ to give 0.5 rem/y maximum dose

to body organ indicated for inhalation of soluble and insoluble ${ }^{239} \mathrm{pu}$. . . . . . . . . . . . . . . . . . . . . 118

H2. Values of $Q_{B}$, in $\mu C i / c c$, that will give a dose rate

of $5 \mathrm{mrem} / \mathrm{y}$ to the bone after $50 \mathrm{y}$ of inhalation

of contaminated dust . . . . . . . . . . . . . . . . . . 123

H3. Calculated inhalation rate, $I_{0}$ in $\mu \mathrm{Ci} / d$ of ${ }^{239} \mathrm{Pu}$

inhaled for $30 \mathrm{~d}$ to give $0.5 \mathrm{rem} / \mathrm{y}$ maximum dose to

worker at site ("Y" class; . . . . . . . . . . . . . . 125

Il. Nuclide-specific parameters and values . . . . . . . . . 129

I2. Site-specific parameters and values . . . . . . . . . . . 130

J3. Preliminary dose calculations . . . . . . . . . . . . . 132 


\title{
ABBREVIATIONS
}

\author{
ADC (U.S.) Atomic Energy Commission \\ AIChE American Institute of Chemical Engineers \\ ALAP As low as possible \\ ALARA As low as reasonably achievable \\ AMAD Activity median aerodynamic diameter \\ ANSI Aret ican National Standards Institute \\ CFR Code of Federal Regulations \\ DOE (U.S.) Department of Energy \\ EPA Environmertal Protection Agency \\ FP Fission products \\ GI Gastrointestinal \\ HLW High-level waste \\ IAEA International Atomic Energy Agency \\ ICRP International Commission on Radiological protection \\ INEL Idaho National Engineering Laboratory \\ LET Linear energy transfer \\ LLL Lawrence Livermore Laboratory \\ LLW Low-level waste \\ IWR Light water reactor \\ MPC a Maximum permissible concentration in air \\ MPC Maximum permissible concentration in water \\ MPF Maximum permissible exposure \\ MPQI Maximum permissible quar terly intake \\ NCRP National Comission on Radiation Protection \\ NEPA National Environmental Protection Act \\ NRC (U.S.) Nucleas Regulatory Commission \\ ORNL Oak Ridge National Laboratory, \\ RCF Reference containment facility \\ RHI Relative hazard index
}


Technical advisory panel

TRU

Transuranic nuclides

wC

Waste classifi cation

WH

waste management 


\section{ABSTRACT}

Several classification systems for radioactive wastes are reviewed and a system is developed that provides guidance on disposition of the waste. The system has three classes: high-level waste (BLW), which requires complete isolation from the biosphere for extended time yeriods; low-level waste (LLW) , which requires containment for shorter periods; and innocuous waste (essentially nonradioactive), which may be disposed of by conventional means. The LLW/innocuous waste interface was not defined in this study. Reasonably conservative analytical scenarios were used to calculate that HLW/LiW interface level which would ensure compliance with the radiological expesure guidelines of $0.5 \mathrm{rem} / \mathrm{y}$ maximum exposure for a few isolated individuals and 0.005 rein $/ Y$ for large population groups. The recomendad HLH/LLiN interface level for ${ }^{239} \mathrm{Pu}$ or mixed transuranic waste is $1.0 \mu \mathrm{ci} / \mathrm{cm}^{3}$ of waste. Levels for other radionuclides are based upan a $r$ isk equivalent to this level. A cost-benefit analysis in accordance with as low as reasonably achievable (ALARA) and National Environmental Protectior. Act (NEPA) guidance indicates that further reduction of this HLW/LLL inter face level would entail. marginal costs greater than $\$ 10^{8}$ per man-rem of dose avoidea. The environmental effects considered were limited to those involving human exposure to radioactivity. 


\section{SUMMARY}

This is the final report for phase 2 of the Lawrence Livermore Laboratory (LLL) project to develop a radioactive warte classification (WC) system for the Nuclear Regulatory Commission. We reviewed existing wC systems and developed a three-class system for solid waste based on ultimate disposition:

- Innucuous waste that may be handled as normal trash because of its very Low radioactive levels.

- Low-level waste (LLW) requiring active confinement (confinement or holdup with controlled or predictably low release rates). This waste class would include materials that, due to their low specific hezard levels and/or short decay times, may be adequately controlled in a suitably designed and operated containment facility.

- High-level waste (HLW) requiring isolation (complete containment with no expected release to the biosphere for extended periods of time). This class of waste will contain radioactive materials of very high hazard potential and/or long decay times.

Figure SI is a schematic of the proposed WC system. No value was set for the innocuous waste/LLW interface because further study is needed to provide a precise and defensible value.

The key to setting the HLW/LLW interface value was to define LLW concentration limits such that guidelines for radiation exposure to the public are not exceeded. To this end, we:

- Defined reasonably conservative exposure guidelines $10.5 \mathrm{rem} / \mathrm{y} \mathrm{max}$ exposure for a few individuals and $0.005 \mathrm{rem} / \mathrm{y}$ for a large group) .

- Reviewed Department of Energy (DOE) LLW disposal facilities.

- Established a model reference containment facility (RCF) for LLW.

- Identified conservative exposure scenarios.

- Determined source terms and release fractions from the RCF. 


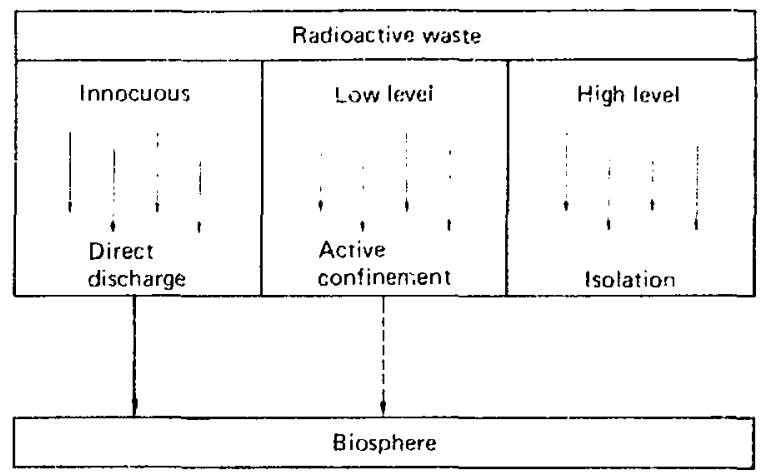

FIG. S1. Proposed waste classification system.

- Described the transport of the radioactivity through the environment to man .

- Calculated the maximum individual dose and the population dose.

- Related these calculated doses to the radiation exposure guidelines.

After these steps were defined, the dose to the exposed population could be related to the concentration of radioactivity in the waste at the time of burial. Figure s2 shows our results for the analytical scenarios. We recommend a HLW/LLW interface level for ${ }^{239} \mathrm{Pu}$ or mixed transuranic waste of $1.0 \mu \mathrm{Ci} / \mathrm{cm}^{3}$. Levels for other $\mathrm{radionuclides}$ are calculated for a $\mathrm{r}$ isk equivalent to this level. A cost-benefit analysis in accordance with ALAPA and NEPA guidance indicates that the cost-effectiveness of reducing the HLW/LLW interface level further would be greater than $\$ 10^{8}$ per man-rem averted. Only those environmental effects related to human exposure to radioactivity were considered. 


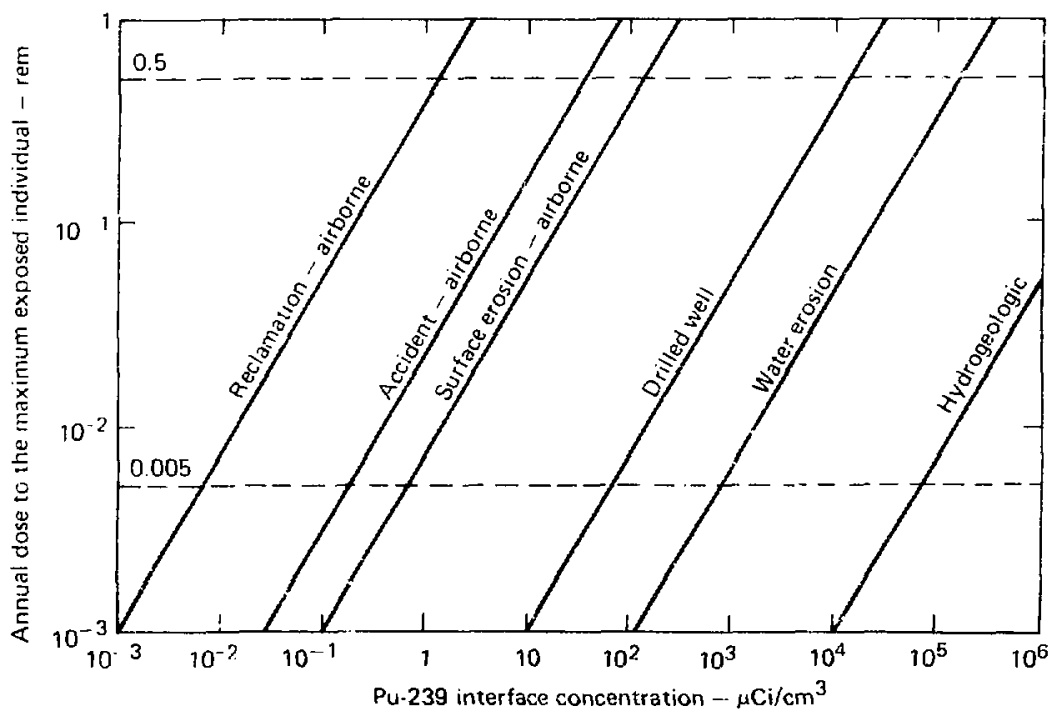

FIG. 52. Annual dose vs ${ }^{239} \mathrm{Pu}$ HLW/LLW interface level for six analyrical scenarios. 


\section{INTRODUCT ION}

The U.S. Nurlear Reg' ${ }^{\prime}$ atory Commission (NRC) has retained the University of California Lawrence Livermore Laboratory (LLL) to provide technical support for its Nuclear Waste Management progeam. A part of this program involves the development of a classification system for radioactive waste. Such a system should be applicable to all sources of radicactive waste, especially the nuclear fuel cycle, which is the predoninant scurce. Projections for light water reactor (LWR) haste production (Fig. I and Tables 1 and 2) ${ }^{2,3}$ provide an idea of the extent of the waste inanagement problem. 


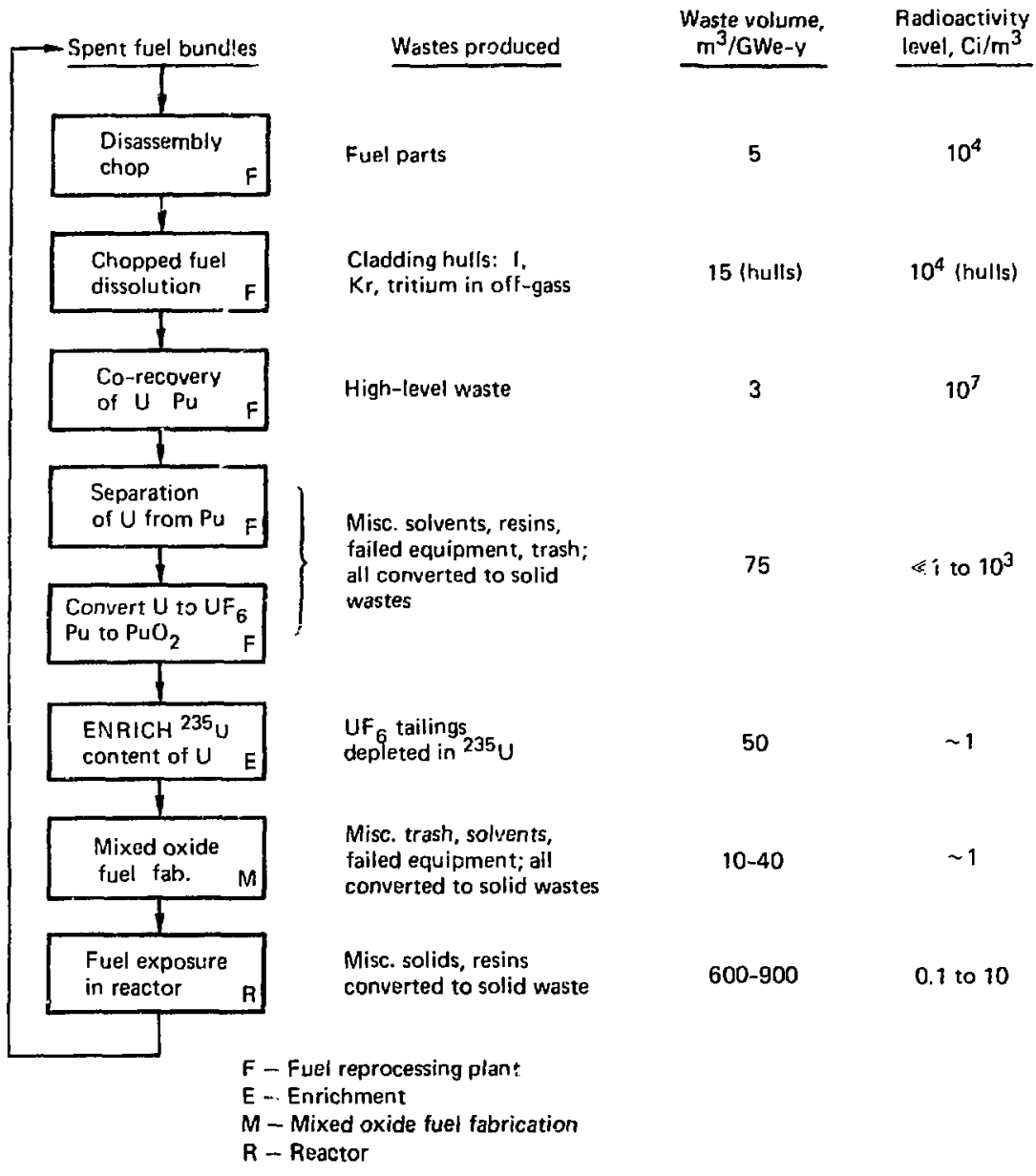

FIG. 1. Process operations and waster in the LisR fuel cycle. ${ }^{2}$ 
TABLE 1. Fuel cycle wastes from generation of 1000 MWe-y by LAR's uging mixed-oxide (U-Pu) fuels.

\begin{tabular}{lllll}
\hline & $\begin{array}{c}\text { Volume, } \\
\mathrm{m}^{3}\end{array}$ & $\begin{array}{c}\text { Activity, } \\
\text { MCi }\end{array}$ & $\begin{array}{c}\text { Mass of } \\
\text { actinides, } \\
\text { tons }\end{array}$ & $\begin{array}{c}\text { Thermal } \\
\text { power, } \\
\mathrm{kW}\end{array}$ \\
\hline Highte type & 3.0 & 01.5 & 0.25 & 450 \\
Cladding hulls & 2.6 & 0.8 & 0.017 & 3.3 \\
Noble gases & 1.0 & 0.24 & - & 0.36 \\
Iodine & 0.049 & $1.25 \times 10^{-6}$ & - & $7.5 \times 10^{-7}$ \\
LWR tritium (water) & 140 & $7.4 \times 10^{-4}$ & - & $2.3 \times 10^{-5}$ \\
FP tritium (solidified) & 0.34 & 0.019 & - & 0.00062 \\
Carbon-l4 & - & $1.56 \times 10^{-5}$ & - & - \\
Low-level TRU & 46 & 0.047 & 0.004 & 0.04 \\
Intermedicte-level TRU & 13.4 & 0.11 & 0.0012 & 0.054 \\
Nontransuranic & 600 & 0.002 & - & 0.0065 \\
\hline
\end{tabular}

Source: Ref. 3

Note: Age of waste is assumed to be approximately $1 \mathrm{y}$. 
TABLE 2. Postfission wasies per GWe-y expected from the LWR fuel cycle.

Waste form
$\begin{gathered}\text { Volume } a, m^{3} \\ \text { (except as noted) }\end{gathered}$ $\begin{gathered}\text { Radioactivity, } \\ \text { ci }\end{gathered}$

Reactor waste:

\begin{tabular}{|c|c|c|}
\hline slurries & $2 \mathrm{E} 2^{\mathrm{b}}$ & $2 \mathrm{E} 1^{\mathrm{C}}$ \\
\hline Sludges & $3 E 1$ & $3 \mathrm{E} 1^{C}$ \\
\hline Resins & $6 \mathrm{El}$ & $4 E 3^{C}$ \\
\hline HEPA Eilters & 5EO & $1 \mathrm{E} 1^{\mathrm{C}}$ \\
\hline Charcoal & $2 \mathrm{EO}$ & $1 E 0^{C}$ \\
\hline irash & $2 \mathrm{E} 2$ & $5 E 0^{c}$ \\
\hline Failed equipment & $6 \mathrm{EO}$ & $2 \mathrm{E} 5^{\mathrm{C}}$ \\
\hline Water filters & $4 \mathrm{EO}$ & $3 \mathrm{E} 2$ \\
\hline
\end{tabular}

Mixed-oxide fuel fabrication wasces

Combustible solids

Noncombustible solids

Liquids, slurries

HEPA filters
$6 \mathrm{El}$

1E1

2E0

$4 \mathrm{EO}$

\section{$9 E_{2}$}

$2 E 2$

3E2

$3 E 2$

Source: V. Trevorrow, Argonne National Laboratory, Argonne, IL, private comunication (1976).

arlumes (except for high-level fuel reprocessing wastes) represent those of primary waste forms, before volume-reducing treatments. ${ }^{b} 1 \mathrm{El}$ to be read as $1 \times 10^{1} ; 1 \mathrm{E}-1$ to be read as $1 \times 10^{-1}$, etc. $c_{\text {Radioactivities of reactor wastes are assumed to be based on surveys at }}$ shipping time, about 6 mo after removal from reactor. 
TABLE 2. (cont'd.)

Fuel Reprocessing Wastes

Waste form Volume, $\mathrm{m}^{3}$

$$
\text { Volume, } \mathrm{m}^{3}
$$

Waste form (except as noted)

Thermal power, kH
Hulls

High-level solid

LOW-level liquid

Gases

krypton

Xenon

Iodine

Car bon-14

Tritium

Non-high-level solids

combustible TRU

Combustible nonTRu

Noncombustible TRU

Noncombustible non'TRU

slurries, sludges, resins TRU

Slurries, sludges, resins nonTRU

Filters TRU

Filters nonTRU
$1 \mathrm{EI}$

$4 \mathrm{EO}$

$1 E 6$

$3 \mathrm{E} 0^{\mathrm{g}}$

$3 E 1^{g}$

gE3 gr

AEO gr

$2 \mathrm{EO} \mathrm{gr}$

$5 E 1$

$3 \mathrm{El}$

$5 E 1$

$1 \mathrm{E2}$

$5 E-1$

$5 E 0$

7EO

$5 E-1$

Based on 5-y cooling after discharge.

Eased on 10-y cooling aftar discharge.

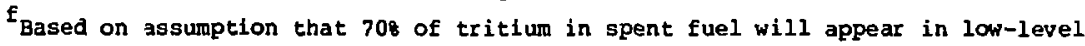
aqueous waste.

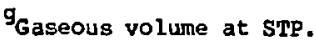


The LLL project was conducted in two phases. The first phase:

- Established the purpose and objectives for the wC system

- Identified and evaluated relevant system paraneters

- Developed a suitable format (classes of waste) for the system. The second phase mostly determined interface values between tie classes of waste.

Phase 1 ended with publication of a working document ${ }^{3}$ covering:

- Sources of wastes containing long-lived $r$ adioactive materials resulting from fuel-cycle activities.

- Data on waste volumas, characteristics, and current status of waste management operations.

- Suggested alternative appi saches and methods for waste classification.

- Evaluation of the identified approaches and discussion of their advantages and disadvantages.

- Selection of an approach and format.

Technical advisory panels (TAP's) of experts from industry, government organizations, and research labolatories assisted the LLL project. Early in its tenure, the Eirst TAP helped to establish four basic objec::ives and requirements for an acceptable WC system. In order of priority ciney are:

1. The protection of public health and safety for present and future generations. It is gener ally recognized that complete and absolute protection (i.e., zero risk) for every inaividuai living now or in the future is impossible. Society will accept some risks if they are low enough ans if the benefits to be derived are seen as outweigning the risks. A rjsk vs benefit evaluation should therefore be part of the founclation for the wC system. This objective is consistent with ALARA guidance and with the intent of the NEPA.

2. The system should have a sound technical basis and should alluw for societal, environmental, or technical issues to be resolved within its framework. The system should, however, be based primarily on technical considerations. 
3. The system should be consistent with good economic practice. A system thit would impose undue economic penalties is unacceptable. Evaluating the operating costs of the system in conjunction with a benefit/risk analysis should provide a sound economir basis for the proposed classification system.

4. The system should be practical for all industries producing radioactive wastes. Generally, the simpler the system, the more practical it becomes to the user.

Since protection of public health and safety is the paramount consideration in the formulation of a WC system, it is important to specify the areas of public healch and safety that are of major significance. In this regard, avoidarce of undue exposure to radioactivity becomes the primary goal, with other potentially adverse health and environmental effects being of seconoary consideration.

As a guide to acceptable radiation exposure, current radiation patection cr iter ia established by the International Commission on Radiological Protection (ICRP), 4 the National Council on Radiation Protection ano Measurements (NCRP), 5 and the code of Federal Regulations (10CFR20) ${ }^{6}$ can specify limits for potential individual exposures. Population exposure (man-rem) limits can be made to be consistent with ALARA guidance. 7

In either case, one must make certain assumptions and develop suitable analytical models to see that the criteria are met. It is important, also, that all assumptions be clearly stated so that the conclusicis may be rationally evaluated.

This report is the final document of the project. It describes the work done, recommends a WC system, and discusses the technical basis for the recommendations. 
DEVELOPMENT OF A CLASSIFICATION FORMAT

Radioactive waste classification (WC) systems generally fall into one of three categories based on the source of the waste, the physical characteristics of the waste, or the waste disposal methods. Factors that could be considered for waste classification include:

- The toxicity or hazard of the waste.

- The total quantity of wasie (in curies, mass, or volume).

- The longevity of the waste (half-life).

- Potential biologicai concentration mechanisms for various types of radioactivity.

- Consideration of whether the waste was natural or manmade.

- Heat production.

- Potential economic value.

- Physical state (solid, liquid, gas).

- Consideration of whether the entire material is considered as waste or whether the waste is a form of contanination of some other valuable material.

- Type of radioactivity ( $\alpha, \beta, \gamma$, neutrons, etc.).

- Requirement for shielding.

In phase 1 of this study, several previously proposed wC systems were reviewed and evaluated in detail as discussed in Appendix C. In addition, certain concepts for WC systems that were prepared by TAP members during phase 1 are reviewed and discussed in Appendix D.

The advantages and disadvantages of the various wC systems were discussed in the TAP meetings in the context of NRC needs as well as needs of industry, government, and waste management operators. The insights from these reviews and discussions have led to certain conclusions and suggest a format for a wC system that might best serve the specified objectives. 


\section{Classification by Source}

Classified according to its source, radicactive wasie could be reactor waste, spent nuclear fuel, reprocessing waste, or Euel fabrication waste. Reprocessing waste can be further identified as spent fuel cladding, liquid process yaste, or general process trash. Because such a classification system reveals little about the nature of the waste or the means to be used for handling, processing, or disposal, it is not a useful system on which to bese waste maragement regulations.

\section{Classification by Physical Characteristics}

Most reported classification systems are based un the physical characteristics of the $r$ adioactive waste. For example, the IAEA recommended in 1970 that radioactive wastes first be classified as solids, liquids, or gases. Liquid and gaseous wastes were then subdiviled by activity levels in units of curies per milliliter or curies per cubic meter. Solid wastes were subdivided by surface radiation dose rate in units of rads per hour. The TAP members generally believed that a WC system should consider physical characteristics of the waste primarily as they affect its hazard potential.

\section{Classification by Disposal Methods}

Different ways to dispose of radioactive wastes have certain common features that lead to broad categories of waste disposal. These features include the degree of containment achievable and the degree of isolation or extent of social comitment required for each disposal option. The TAP members agreed that for regulatory purposes a WC system should be based on disposal methods. 
Tha final disposal of $r$ adioactive wastes can be considered the most important operation in any radioactive waste management program. It is also the operation that requires the most definition. A wC system based on disposal options should provide information and guidance allowing maximum flexibility for implementing waste management programs by the waste generating facilities.

There are many possible waste disposal methods and a wC system based on method of disposil must be broad enough to include them all. Some suggested methods include:

- Direct discharge or dispersal to either the atimosphere or surface water.

- Storage until the radioactive isotopes have decayed to an innocuous level.

- Shallow land burial.

- Ocean dumping.

- Deep geological emplacement.

- Ice cap emplacement.

- Extratercestrial disposal.

- Ocean disposal (seabed burial).

- Deep rell injection.

- Shale fracturing.

These methods vary according to the degree of containment, isolation, and social comitment. For example, direct dispersal to the environment provides no confinement while deep geological emplacement should provide essentially complete containment and isolation for geological periods of time. Social commitment refers to such ongoing functions as record keeping, syst.ems and security maintenance, and system and environmental monitoring. Management systems such as surface storage or shallow land burial require significant social and resource commitment for w extended period of time--long after the disposal facility is actually receiving radioactive material. By contrast, deep geological emplacement--after the operational phase is discontinued-would require minimal social comnttment to the extent of preventing mining or drilling into the reglon surrounding the waste materials. 
It is possible to formulate a WC system based on disposal methods without being limited to the means of disposal. All disposal systems fall into one of three categories:

1. Dispersal to the environment (nonradioactive waste)
a. Stack discharges
b. Liquid effluent discharges
c. Disposal of solids to sanitary land fills

2. Disposal methods requiring social comnitment (low-level waste)
a. Shallow land burial
b. Storage near surface
c. Ocean dumping
d. Deep well injection

3. Disposal methods providing long-term isolation (high-level waste)
a. Deep geological emplacement
b. Ice cap emplacenent
c. Extraterrestrial disposal
d. Oceanbed disposal

The above disposal methods have been proposed or used in the past. They are not necessarily feasible or acceptable.

\section{BASES FOR DEFINING WASTE CLASSES}

Categorizing the various waste disposal methods helps in classifying radioactive waste materials because we can establish appropriate interface values between disposal categories. Figure 2 lists a number of considerations thit may be important in deciding what type and amount of radioactive waste can be disposed of by the various methods. The list is meant to allow for the broadest possible approach by the regulatory agencies that must prepare waste management criteria and regulations. 


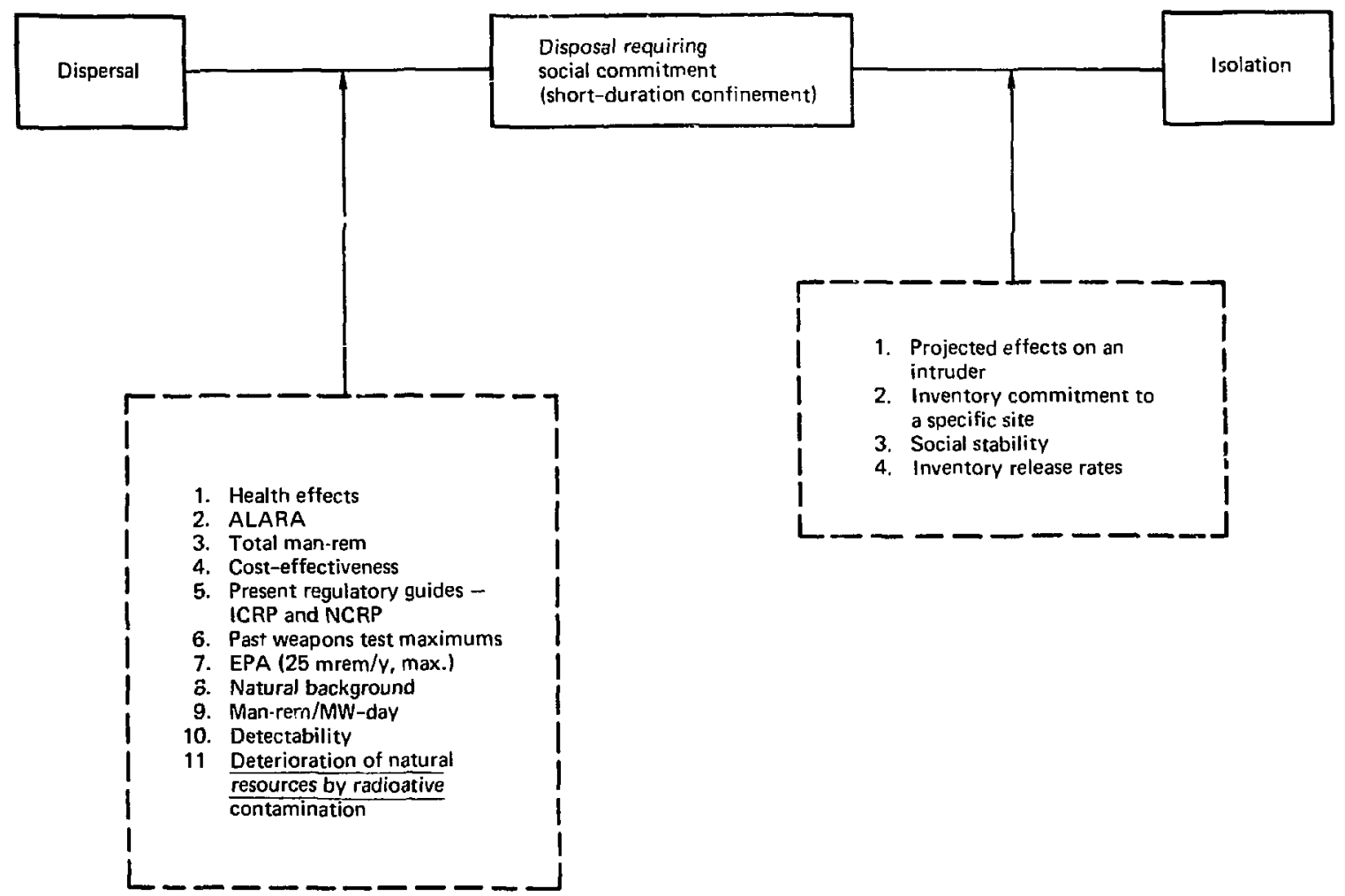

FIG. 2. Considerations for applying waste disposal methods. 
Items 1 through 11 in Fig. 2 celate to the waste management criteria that would dictate whether a material could be dispersed or whether it would have to be contalned. The TAP judged that the primary goal of any waste management program should be to limit the potential radiation dose to man. Accoringly, nine of these items deal with closely related aspects of the dose-to-man question.

Several different types of criteria could be established to limit the type and amount of radioactive material released to the environment by dispersion. For example, absolute values could be set for one or more of the following: tolal health effects; total man-rem; man-rem per unit of electric power oenerater; cost-effectiveness guidelines (for radiation protection); and maximum credible dose to any indivicudal or critical group. Any dispersal to the environment that exceeds a predetermined value would have to be captured or treater. The radioactive material resulting from such capture or treatment would than have to be disposed of by a method in one of the two waste containment categories.

A second means of formulating waste management criteria might be to use existing regulations and regulation guides. For example, present ICRP and NCRP standards could be used to establish dispersal limits. Also, the EPA's proposed individual dose limit of $25 \mathrm{mrem} / \mathrm{y}$ from nuclear fuel cycle operations, including waste disposal, could also serve as a guide to limit the quantity of radioactive material that could be dispersed to the environment.

Another approach is to establish an acceptable man-rem cost-effectiveness value. For example, 10CFR50, Appendix $I,{ }^{7}$ sets a value of $\$ 1000 /$ man-rem. Thus, any method of reducing population exposure that has a marginal cost of $\$ 1000 /$ man-rem or less should be used. A different approach would lie in a regulatory philosophy that says the dose to man shall be ALARA. This philosophy is already implied by paragraph 20.1 (c) of 10CFR20. ${ }^{6}$ Such guidance, however, would have to be translated into practical criteria. The previously cited examples, in terms of dollars per man-rem or man-rem per MWe-y, may suffice. Some other approach might also be in order. 
Of the first group of considerations lieted in Fig. 2, two do not deal directly with dose to man: detectablity and deterioration of natural resources. Some people believe strongly that no level of dispersal of radioactive material to the environment is acceptable. If zero relsase were to be adopted as a waste management criterion, the anount of material that could be released by dispersion would essentially be limited by our ability to detect radióctivity. A strict, literal interpretation of zero release would thus preclude any ogerations that involve radioactivity.

Deterioration of natural resources addresses itself mainly to ${ }^{85_{K r}}$ releases, which contaminate natural krygton in the atmosphere. A waste management criterion might be basea on acceptable levels of resource deterioration by treating certain substances or environments as potential resource bases.

A combination of two or more of the approaches discussed could proside for the development of acceptable regulations and waste management criteria. For example, an ALARA regulatory philosophy together with a cost-effective calculation and a haximum acceptable health effect or individual dose limit might serve to define what could be dispersed, what would require containment, and what must be isolated for long time periods. 
Figure 2 also lists waste management criteria that might be used to determine the type and amount of radioactive material that can be disposed of by conf inement as opposed to isolation.

Shallow land burial can be used as an example to discus 3 this second set of criteria. With regard to shallow land burial, the TAP generally reached the following conclusions:

1. Shallow land burial is a disposal method that requizes ongoing social commi tment.

2. During operation and for the $f$ irst $100 \mathrm{y}$ after decommissioning of a shallow land hurial site, some low-level discharge to the environment can be expected.

3. The magnitude of the releases is a function or such factors as site location, area rainfall, geology, hydrology, engineering features, and operation procedures. Release $r$ ates are site specific and depend on these factors.

4. Surface geology can change significantly in time periods as short as 5,000 to $25,000 \mathrm{y}$. Social and institutional patterns can also be expected to change during these time periods. Consequently, near-surface stor age or disposal systems should not be used for long-term isolation of radioactive material.

5. Some release of radioactive material to the environment from radioactive waste management programs is ucceptable.

6. For a shallow land burial site, and with specific information on meteorology, geology, hydrology, engineering design, and other relevant factors, it is possible to estimate the amount of radioactive material that would be released from that site uver a period of perhaps a few hundred years.

7. A conservative estimate of the dur ation of social commitment required for a disposal site is no more than a few hundred years. 
similar statements can be made about gtorage facilities, ocean dumplng, or doep well injection. They include:

- Degree of contaiment is procedure and site specific.

- Long-term containment $(>2000$ y) cannot be guaranteed.

- Releases can be egtimated for various time frames.

The TAP members reviewed the possible face of radioactive material disposed of by the shallow land burlal method and recommended that two time frames be conaidered--the operational phase of the burlal ground and the first few hunjred years after decommissioning, and the subsequent period.

During the first time frame, release of radioactive material to the environment depends on specific site characteristics, engineering features, and operational procedures. The TAP members generally thought that enough data could be obtaired to predict the release of radioactivity from a given site, or at least specify a range of values that would characterize this release. They believed that the release rate (fractional release) can be assumed to be constant for each site, whereas the total quantity released is a function of the site inventory. Accidental intrusion during the first few hundred years was not considered a problem because of the availability of site records and security systems.

For the first few hundred years, therefore, total site inventory is the factor that should be controlled and regulated. Our previous discussion of waste management criteria for dispersal could also apply to determining acceptable release from a shallow land burial site.

It was assumed that no records of the site would exist and no security system would be operating after a few hundred years. The site could become an agricultural area or part of a potable water supply system. Therefore, the inventory of radioactive material remaining at the site is important. A detailed analysis of the possibie pathways to man from such a site must be done, and a set of waste management criteria must be formulated to define what an acceptable dose to man might be at some time in the future. The criteria 
for an acceptable onse to man in the future may or may not be the same as those applied to the present population.

Without site records and security, such intrusion as drilling, mining, or surface excavation may occur. To prevent injury to anyone disturbing the site after a few hundred years, the concentration of radioactive material in any one waste package may have to be limited.

As indicated earlier, numerical values for any limit on waste inventory or concentration would preferably be method and site specific. It is important to note that total curies of activity would probably not be the units chosen to define either the inventory or concentration limits. A hazard index should be used instead. Inventory limits could be based on the volume of water required to dilute the total site inventory to maximum permissible concentration in water $\left(M P C_{w}\right)$ limits. The reason for using $M P C_{w}$ as a basis is that the inventory limits are intended to restrict the quantity of radioactive material slowly released from a given site. Since the dose to man from the material released might largely result from water in the food-chain pathway, $M P C_{w}$ is only an indication and not a direct measure of the potential risk.

Another consideration in setting absolute inventory limits is that radioactive materials decay. Hence, the total hazard index for a given site is always changing. During the first time frame, corrective steps can be taken if higher-than-expected releases occur, while during the second time frame, release is assumed to be undetected. Consequently, the inventory limits for the first time period may be several times greater than those for the second. Large quantities of short-lived radioactive isotopes could be disposed of by methods requiring long-term social commitment, but the amounts of longer-lived radioactive isotopes might be limited. Detailed analysis of the specific disposal method and disposal site is required to determine which of the three limits above would be controlling. 
The question of whether wastes containing transuranic (IRU) nuclides should be given special consideration, as has been done in the past, was discussed as a separate issue. The TRU properties used to justify placing them in a separate category are:

- Extremely long half-lives.

- High toxicity.

- Emiggion of alpha rays having a high linear energy transfer.

- Manmade origín.

- Potential for criticality accidents in sufficiently high quantities and concentrations.

- Detectability of extremely small quantities.

Assegsment indicates that, except fir the criticality potential, none of the identified TRU properties is unique. In the context of radioactive waste, where the TRU would be mixed with large quantities of diluent material, the possibilities of criticality are insignificant. Where the TRU concentration would be high enough to pose a criticality problem, the material could be viewed as a valuable resource rather than a waste. Although the TRU isotopes are highly toxic becauge of their high speciflc radiotoxicity, they are not the most toxic material known to man and should be viewed in proper perspective. Previous studieg indicate no technological basis for distinctive treatment of TRU as opposed to other radioactive materials. 8,9 
PROPOSED FORMAT AND GUIDELINES FOR A WC SYSTEM

The waste classification system should be based on the ultimate disposition of the waste material. Although a classification system is definitely needed for guidance in disposal operations and in the handling of radioactive wastes, the need is primarily to give dizection on the disposition of the wastes. Waste generating facilittes could te designed to generate the waste in the optimum form for safe and economical disposal.

For present purposes, it may be assumed that all waste handling operations will comply with existing standards, regulations, and rules of good practice (i.e., shlelding, heat dissipation, etc., will be provided where required). The main object of the present work is to provide guidance to the waste producer regarding the final disposition of the waste.

This does not preclude the need for an operational WC system to provide guidance on waste handling operations. It was noted, however, that optimally designed operational WC systems might best be designed individually to meet the specific needs of various waste handing facilities.

An adequate and acceptable WC system can best be defined by three waste classes. (For present needs and purposes the proposed waste classification system will apply only to solid radioactive waste forms.):

- Non-radioactive waste that may be handled as routine trash because of its innocuously low radioactive levels.

- Low-level waste requiring active confinement (Confinement or holdup with controlied or predictably low release rates). This waste class would include materials that, due to their low specific hazard levels or short decay times, may be adequately controlled in a suitably designed and operated containment facility.

- High-level waste requiring isolation (complete containment with no expected release to the biosphere for geological periods of time). This class of waste will contain radioactive materials of very high hazard potential or long decay times. 
Figure 3 is a schematic of the proposed $w$ system and shows that it meets the objective for simplicity. Provision of a more complicated system is not necessary and might even be counterproductive.

Alpha emitting material including transuranics are not classified separately but should followi essentially the same disposal criteria as other radioactire waste material.

In the classification system, the method governing the disposition of waste should be based primarily on the hazard potential (hazard index, longevity, and migration) and expressed in terms of radioactivity per unit volume or mass at the time of disposal.

Because small release rates are possible during active confinement of low-level wastes (dotted line in Fig. 3), total inventory limits may be required for all such facilities.

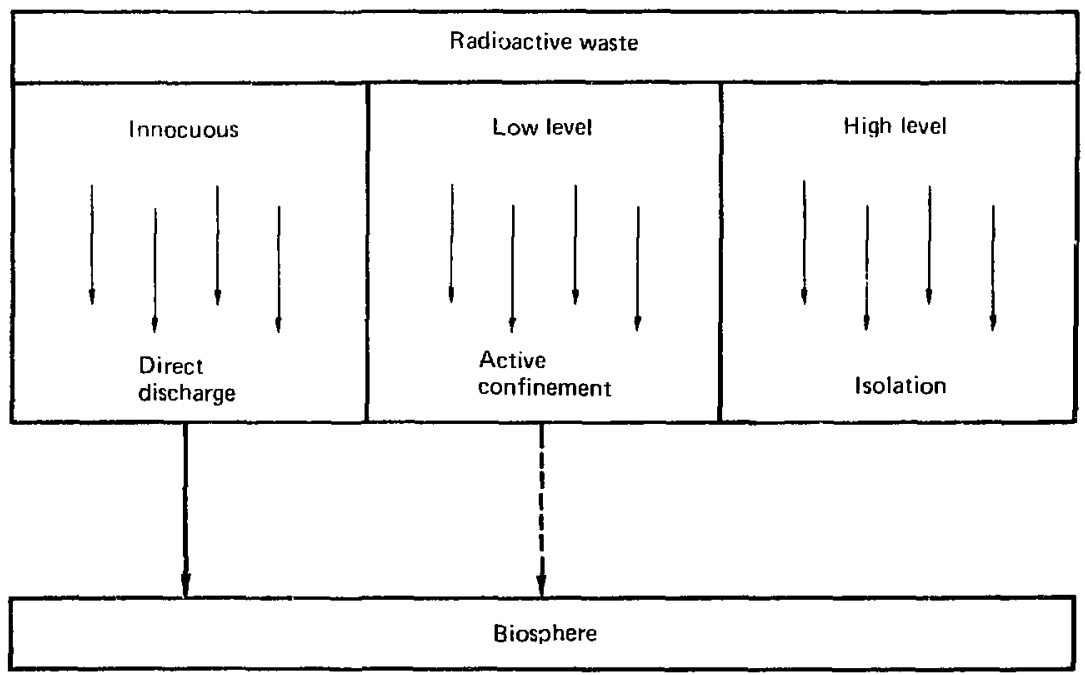

EIG. 3. Schematic of proposed radioactive waste classification system. 
ESTABLISHIN INTERFACE LEVELS

The key to establishing quantitative interface levels between the three proposed waste classes iies in defining the concentration limits for radioactive waste in the LIN class so that guidelines for radiation exposure to the public are not exceeded.

Radiation guidelines are defined on the basis of the annual dose equivalent that the public might receive from exposure to the radioactive material in the waste. As a guide in this study, a maximum annual dose equivalent of $0.5 \mathrm{rem} / \mathrm{y}$ was used when the exposure involved a few individuals. When the potential size of the exposed population was large, $0.005 \mathrm{rem} / \mathrm{y}$ was used.

Current practice in the United States is to dispose of LLW by shallow land burial. There are now six commercial LLW burial facilities and the U.S. Department of Energy (DOE) operates five other major facilities.

We reviewed the characteristics of these facilities to establish conservative yet cealistic parameters as input to a computational model based on a reference containment facility (RCF). Table 3 summarizes data on these existing facilities. Appendix $F$ covers the review in more detail.

Releases of radioactivity from the RCF can be estimated from analyses of present LLW. Projections of the activities and volumes of wastes to be generated in the future are also important in determining the relative costs and potential risks associated with LLW containment facilities. Table 4 gives the character istics of radionuclides generated in light water reactors (LWR) and destined to be treated as LLW. ${ }^{10}$ Table 5 gives the estimated volume and radioactive concentration of four waste classes generated per GWe-y by LWR's. ${ }^{2}$ 
TABLE 3. Survey of existing low-level waste disposal facilities.

\begin{tabular}{|c|c|c|c|c|c|}
\hline Location & $\begin{array}{l}\text { Commercial } \\
\text { capacity, } \\
\mathrm{m}^{3}\end{array}$ & Climate & $\begin{array}{l}\text { Nearby } \\
\text { rivers }\end{array}$ & $\begin{array}{l}\text { Cover } \\
\text { depth. } \\
\pi\end{array}$ & $\begin{array}{l}\text { Observed } \\
\text { radionuclide } \\
\text { migration }\end{array}$ \\
\hline $\begin{array}{l}\text { Han ford, } \\
\text { Washing ton }\end{array}$ & --- & Semi ar id & $\begin{array}{l}10 \mathrm{~km} \text { to } \\
\text { Columbia }\end{array}$ & 2.5 & $\begin{array}{l}\text { Through uptake } \\
\text { by deep rooted } \\
\text { plants }\end{array}$ \\
\hline $\begin{array}{l}\text { Richland, } \\
\text { Washing ton a }\end{array}$ & $9 \times 10^{5}$ & Semiar id & $\begin{array}{l}10 \mathrm{~km} \text { to } \\
\text { columbia }\end{array}$ & 2 & Not observed \\
\hline $\begin{array}{l}\text { Beatty, } \\
\text { Nevada }\end{array}$ & $7 \times 10^{5}$ & Arid & $\begin{array}{l}3 \mathrm{~km} \text { to } \\
\text { Amargosa }\end{array}$ & 2 & Not observed \\
\hline $\begin{array}{l}\text { INEL, } \\
\text { Idaho a }\end{array}$ & -- & Semiar id & $\begin{array}{l}3 \mathrm{~km} \text { to } \\
\text { Big Iost }\end{array}$ & 1 & $\begin{array}{l}\text { Possibly by } \\
\text { on-site ground- } \\
\text { water }\end{array}$ \\
\hline $\begin{array}{l}\text { Los Alamos, } \\
\text { New Mexicoá }\end{array}$ & $-\infty$ & Semiarid & $\begin{array}{l}8 \mathrm{~km} \text { to } \\
\text { Rio Grande }\end{array}$ & 1.5 & $\begin{array}{l}\text { On-site vadose } \\
\text { water zone }\end{array}$ \\
\hline $\begin{array}{l}\text { Sheffield, } \\
\text { Illinois }\end{array}$ & $2 \times 10^{5}$ & Humid & $\begin{array}{l}\text { site } \\
\text { boundary }\end{array}$ & 1 & Not observed \\
\hline $\begin{array}{l}\text { Morehead, } \\
\text { Keintucky }\end{array}$ & $3 \times 10^{6}$ & Humid & $500 \mathrm{in}$ & 1 & $\begin{array}{l}\text { On and off-site } \\
\text { ground and } \\
\text { surface water }\end{array}$ \\
\hline $\begin{array}{l}\text { Oak Ridge, } \\
\text { Tennessee }\end{array}$ & -- & Humid & On-site & 1 & $\begin{array}{l}\text { On-site ground- } \\
\text { water, off-site } \\
\text { surface water }\end{array}$ \\
\hline $\begin{array}{l}\text { Savannah River, } \\
\text { South Carolinaa }\end{array}$ & -- & Humid & $\begin{array}{l}\text { On-si te } \\
\text { Savannah }\end{array}$ & 1.2 & $\begin{array}{l}\text { Or:-site } \\
\text { groundwater }\end{array}$ \\
\hline $\begin{array}{l}\text { Barnwell, } \\
\text { South Carolina }\end{array}$ & $2 \times 10^{6}$ & Humid & $\begin{array}{l}\text { site } \\
\text { boundary }\end{array}$ & 3 & Not observed \\
\hline $\begin{array}{l}\text { West Valley, } \\
\text { New York }\end{array}$ & $2 \times 10^{5}$ & Humid & On-site & 3 & $\begin{array}{l}\text { On-site ground- } \\
\text { water, off-sit.. } \\
\text { surface water }\end{array}$ \\
\hline
\end{tabular}

aDOE sites 
TABLE 4. Calculated concentrations of cadionuclides in LWR solid wastes shipped to commercial burial grounds.

\begin{tabular}{|c|c|c|c|}
\hline Nuclide & $\begin{array}{c}\text { Halt-life, } \\
y\end{array}$ & $\begin{array}{l}\text { Soncentration, } \\
\qquad \mathrm{C} / \mathrm{m} \mathrm{m}^{3}\end{array}$ & $\begin{array}{c}\text { Total activity. } \\
\text { Ci/Gwe-y }\end{array}$ \\
\hline \multirow{4}{*}{$\begin{array}{l}{ }_{\mathrm{H}} \\
60_{\mathrm{Co}} \\
137 \mathrm{Cs} \\
124 \mathrm{Cs}\end{array}$} & 12.3 & 7.06 & 4449 \\
\hline & 53 & 2.47 & 1557 \\
\hline & 30.1 & 1.76 & 1112 \\
\hline & 2.06 & 1.06 & 667 \\
\hline \multirow{5}{*}{$\begin{array}{l}{ }^{51} \mathrm{Cr} \\
55 \mathrm{Fe} \\
{ }^{54} \mathrm{Mn} \\
90 \mathrm{Sr} \\
238 \mathrm{Pu}\end{array}$} & 0.075 & 1.06 & 667 \\
\hline & 2.7 & 0.71 & 445 \\
\hline & 0.85 & 0.35 & 222 \\
\hline & 29 & 0.0035 & 2 \\
\hline & B7. B & 0.0035 & 2 \\
\hline \multirow{6}{*}{$\begin{array}{l}{ }^{239} \mathrm{Pu} \\
241 \mathrm{Pu} \\
237 \mathrm{~Np} \\
241 \mathrm{Am} \\
242 \mathrm{Cm} \\
244 \mathrm{Cm}\end{array}$} & 24,400 & 0.0035 & 2 \\
\hline & 15 & 0.035 & 2 \\
\hline & $2,100,000$ & 0.0035 & 2 \\
\hline & 433 & 0.0035 & 2 \\
\hline & 0.45 & 0.0035 & 2 \\
\hline & 17.9 & 0.0035 & 2 \\
\hline \multirow{4}{*}{$\begin{array}{l}59 \\
{ }^{\mathrm{Ni}} \\
99 \\
\mathrm{TC} \\
129 \\
{ }_{\mathrm{I}}\end{array}$} & 8,000 & 0.0014 & 0.9 \\
\hline & 213,00 & 0.0003 & 0.02 \\
\hline & $15,900,000$ & 0.00001 & 0.004 \\
\hline & Total & 14.53 & 9136. \\
\hline
\end{tabular}

Source: Ref, 10, Append $\mathrm{x}$ H. 
TABLE 5. Projected relative waste concentrations and volumes per GWe-y.

\begin{tabular}{|c|c|c|c|}
\hline \multirow{2}{*}{$\begin{array}{l}\text { Waste categorles } \\
\text { as generated }\end{array}$} & \multicolumn{2}{|c|}{$\begin{array}{l}\text { Gross radioactivity } \\
\text { concentration, } \mathrm{C} i / \mathrm{m}^{3}\end{array}$} & \multirow{2}{*}{$\begin{array}{l}\text { Vol ume, } \\
\mathrm{m}^{3} / \text { Gwe-y }\end{array}$} \\
\hline & Upper limit & Average & \\
\hline Routine low-level & 100 & 20 & 660 \\
\hline Intermediate level 1 & 1,000 & 350 & 75 \\
\hline Intermediate level 2 & 10,000 & 3,500 & 20 \\
\hline High-level & $10,000,000$ & $3,500,00$ & 3 \\
\hline
\end{tabular}

Source: Ref, 2 .

The RCF used as our model is described in the appendixes. It is a shallow land burial facility assumed to be in a semi-arid region and located $1 \mathrm{~km}$ from a large river. An aquiter lies $10 \mathrm{~m}$ below the bottom of the burial trenches; the water in this aquifer flows toward the river at a velocity of $111 \mathrm{~m} / \mathrm{y}$ (1 $\mathrm{ft} /$ day). The total capacity of the RCF is $6 \times 10^{5} \mathrm{~m}^{3}$, large enough to contain the volume of LLW generated by 1000 GWe-y of nuclear power production. Figure 4 is a schematic drawing of the RCF. Table 6 lists the parameters used in describing the behavior of the buried wastes in the RCF.

The methodology for determining the waste class interfaces involves five basic steps:

- Identifying a set of conservative exposure scenarios.

- Determining the transport of the radioactivity through the environment to man.

- Calculating both the maximum Individual dose and the total population ase.

- Relating these calculated doses to the radiation exposure guidelines. once these steps are defined, the dose to the exposed population can bt related to the concentration of radioactivity in the waste at the time of burial. 


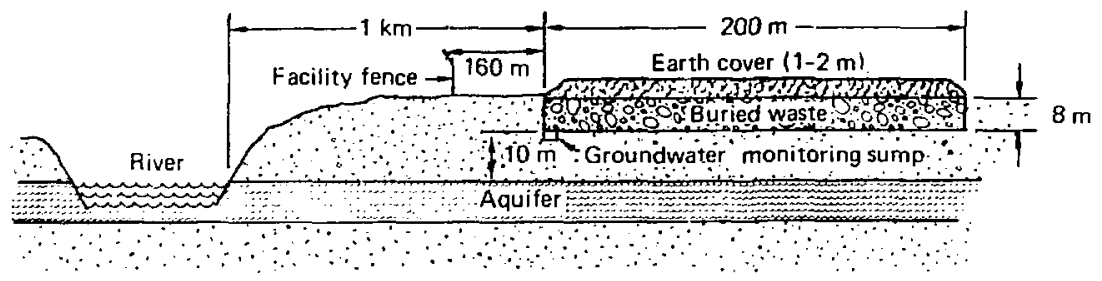

FIG. 4. Schematic of reference containment facility.

TABLE 6. Reference containment facility parameters and values.

value

site plan area, $\mathrm{m}^{2}$

$2 \times 10^{6}$

size of trenches--length, width,

$$
\text { depth, } \mathrm{m}
$$

$200 \times 10 \times 8$

Number of pits

100

Distance to site boundary, m

160

Distance between pit and aquifer, $m$

10

water velocity from pit to aquifer, $m / y$

10

Annual precipitation, $\mathrm{m} / \mathrm{y}$

$0.1-2$

Aquifer flow area, $\mathrm{m}^{2}$

1000

Distance from site to surface water, $\mathrm{km}$

1

Aquifer water velocity, $\mathrm{m} / \mathrm{y}$

111

Dispersion coefficient, $\mathrm{m}^{2} / \mathrm{y}$

0.42

Meterology - Pasquill stability

$$
\text { conditions }
$$

Average windspeed, $\mathrm{m} / \mathrm{sec}$

Bulk soil and waste density, $\mathrm{g} / \mathrm{cm}^{3}$

Reference dust loading, $\mathrm{mg} / \mathrm{m}^{3}$
$\mathbf{E}$ and $\mathbf{F}$

1.6

2

2 
MODEL ASSUMPTIONS

The interface level can be based on volume concentration, which simplifles the process of determining the classification of any given waste container.

The major exposure to the general public from radioactive waste released to the environment results from deposition of the radionuclides in the body. Deposition occurs after the radloactive material enters the body by any of four different mechanisms: ingestion, inhalation, injection (as from a wound), or infusion (where the radionuclide passes through the skin bacrier into the bloodstream). The two entry pathways of most concern are ingestion and inhalation. Therefore, this analysis is limited to thege two eitry pathways.

The scenarios selected for study were as follows:

1. Inhalation Exposure

a. Reclamation and reuse of the burial site after institutionai controls were removed.

b. Continuous airborne releases due to wind erosion of soil. from the disposal site.

c. Airborne release caused by an accident at the site during the operation phase.

2. Ingestion Exposure

a. Leaching of the radionuclides into an underground aquifer that ultimately discharges into a surface stream and hence to human food and water.

b. Erosion of the overfill cover with transport of the cadionuclides by surface runoff to a nearby river and hence to human food and water.

c. Fell drilling and consumption of the water directly below the disposal site.

Figure 5 diagrams the exposure pathways. 
Shallow land burial facility

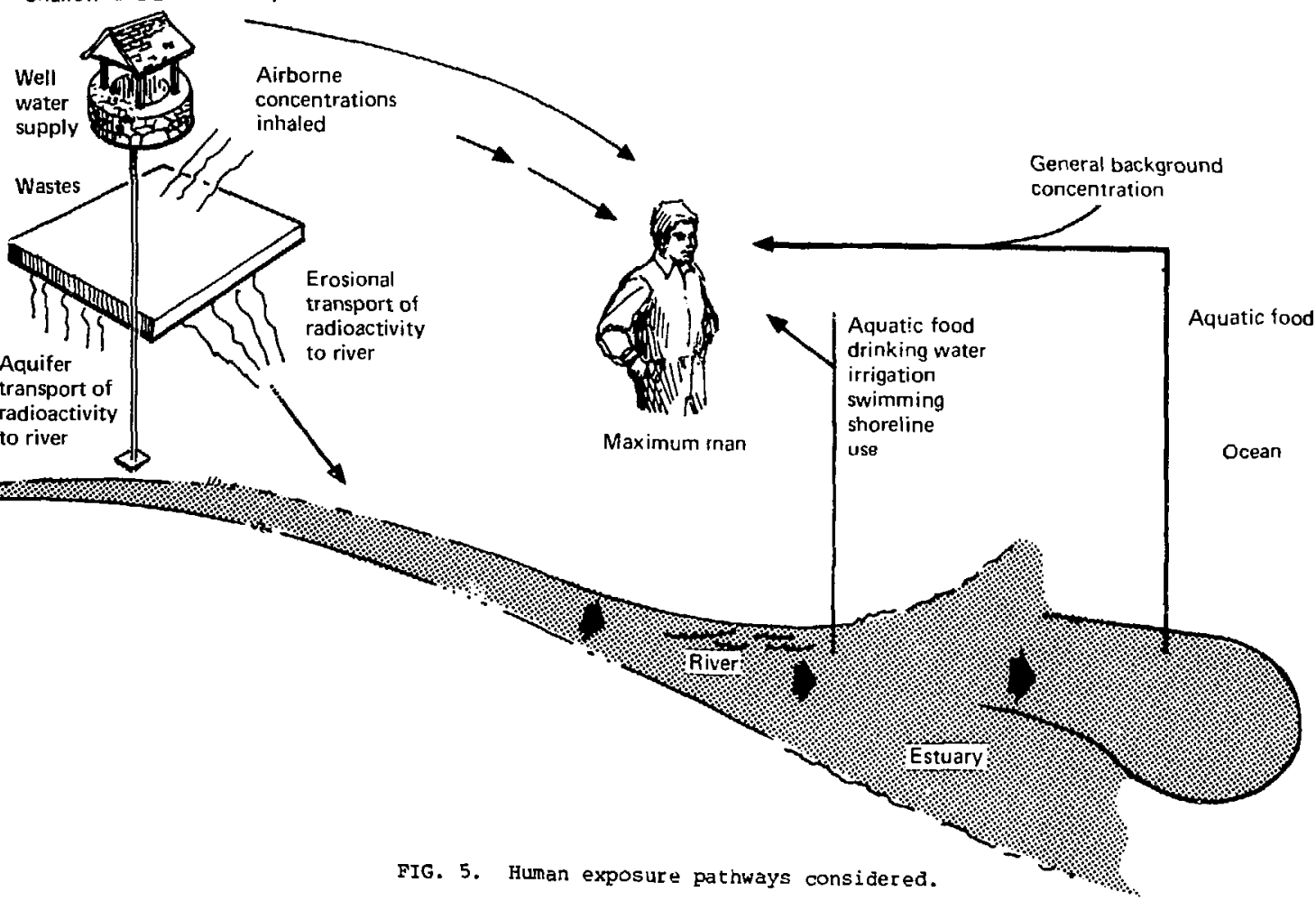


The source terms and release fractions from the RCP were based partly on assumptions and partly on empirical data. The assimptions are identified in the detailed calculations. We believe them to be conservative. Tables 6 and 7 show the data used in determining the source terms. The volumetric concentration in the RCF after burial is assumed to be 30 times less than the maximum permitted concentration in waste containers at time of burial. We arfived at this factor by assuming a dilution factor of 3 due to the surrounding soil mixing with the waste during burial, and a factor of 10 from the $r$ atio of peak concentration to the average waste concentration.

The $t r a n s p o r t$ of the radioactivity through the environment to man was defined using empirical data. In the case of airborne transport, we used the pasquill diffusion equations to determine the concentration of activity downind.

TABLE 7. Nuclide-specific parameters and values.

\begin{tabular}{lrrr}
\hline Nuclide & $\begin{array}{l}\text { Reference } \\
\text { inventory, Ci }\end{array}$ & $\begin{array}{l}\text { Sorption } \\
\text { coefficiant }\end{array}$ & $\begin{array}{l}\text { Reference } \\
\text { leach rate, } y^{-1}\end{array}$ \\
\hline${ }^{90} \mathrm{Sr}$ & 24,000 & 100 & $1 \times 10^{-2}$ \\
${ }^{129} \mathrm{I}$ & 0.73 & 1 & $1 \times 10^{-2}$ \\
${ }^{137} \mathrm{Cs}$ & 35,000 & 1,000 & $1 \times 10^{-2}$ \\
$237_{\mathrm{Np}}$ & 12,000 & 100 & $6 \times 10^{-2}$ \\
$239 \mathrm{Pu}$ & 65,000 & 10,000 & $6 \times 10^{-4}$ \\
$241_{\mathrm{An}}$ & 65,000 & 1,000 & $6 \times 10^{-4}$ \\
\hline
\end{tabular}


In the case of water transport, we determined the leached nuclide migration in the aquifer from a second-order differential mass-balance equation that considers longitudinal dispersion, convection, sorption, and radioactive decay.

The calculations determining source terms and resulting dose to the public from airborne releases are detailed in Appendix $H$. The calculations for water transport are given in Appendix $I$.

DOSE CALCULATIONS

The toxicity or harm to man from a radionuclide present in the body depends on the specific activity of the nuclide, its chemical form, and the mode of entry into the body. The chemical form of thr radionuclide affects the solubility in the body, which in turn determines the rate of translocation to and from the organs of the body. Three categories of solubility are defined by the ICRP. Il These are the "D" class (readily soluble), the "W" class (moderately soluble), and the "Y" class (relatively insoluble). Ingested insoluble compounds containing radioactive elements tend to pass through the gastrointestinal tract with little uptake. When inhaled, however, a significant fraction of insoluble material can remain in the lungs for as long as several years.

Dos's for airborne exposures using recent ICRP data ${ }^{12}$ on the reference man were calculated using the AERIN code developed at LLL. ${ }^{13}$ Examples of computed organ doses due to inhalation of ${ }^{239} \mathrm{Pu}$ are given in Figs. 6 and 7 for short-term and prolunged exposures respectively. Ise of ICRP data on reference man results in lower maximum permissible concentrations in air and water than the current guides given in 10CFR20. ${ }^{6}$ Care should therefore be exercised in compazing these values with 10CFR20 and appropriate correction factors should be applied for valid comparisons.

We determined that for mixed TRU waste, it would be fairly conservative to assume all the alpha radiation emanated from ${ }^{239} \mathrm{Pu}$ decay. Table 8 gives organ doses for TRU mixtures aged $6 \mathrm{mo}$ and $100 \mathrm{y}$ relative to those for ${ }^{239} \mathrm{Pu}$. 
A number of isotopes were investigated in each of the exposure pathway scenarion. These lsocopes were selected to represent the worst case in any given scenario. Other isotopes were then scaled to the appropriate reference 1sotope by the ratio of their radiologic effects from air and water pathways to obtain interface values for each isotope of concern.

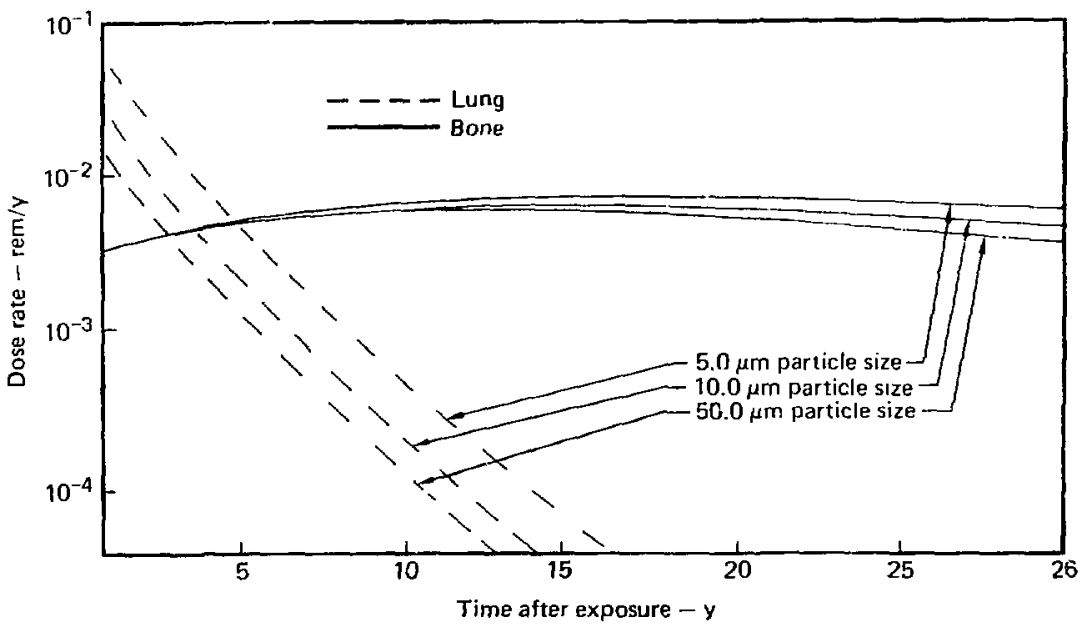

FIG. 6. Effects of short-term inhalation (500 pCi/d for 30 d) of ${ }^{239} \mathrm{pu}$ oxide. 


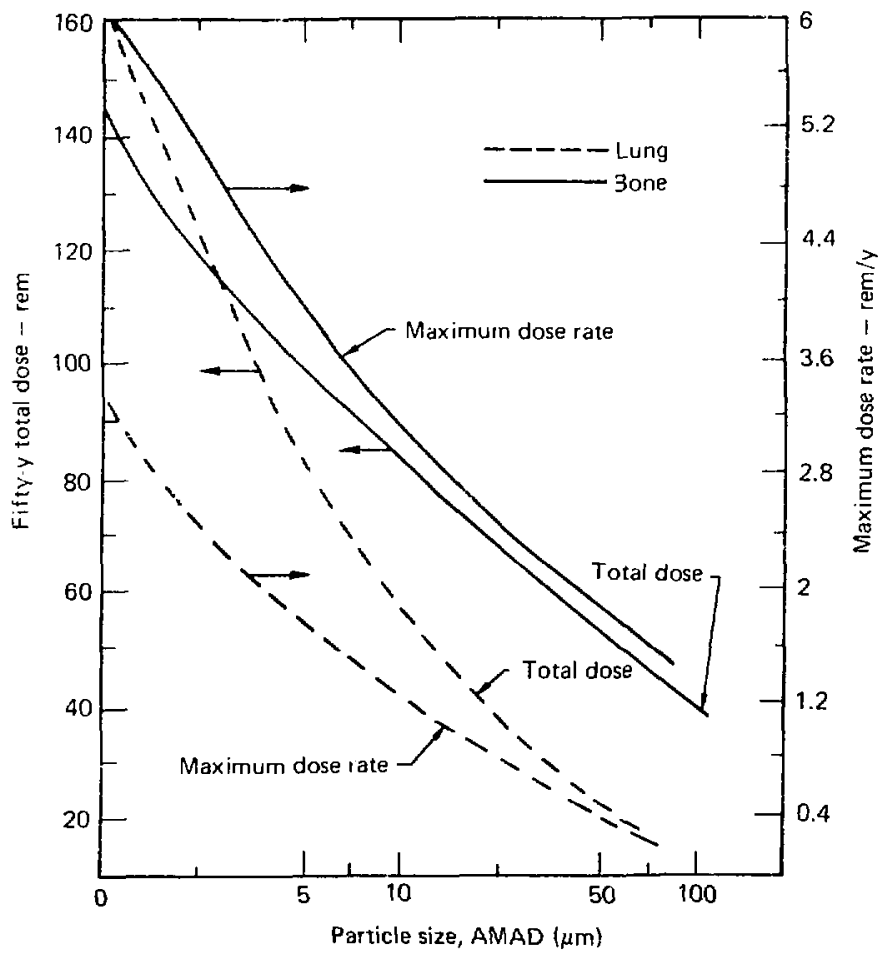

FIG. 7. Dose resulting from continuous 50-y inhalation exposure to $1.0 \mathrm{pC} 1 / \mathrm{m}^{3}$ air concentration of ${ }^{239} \mathrm{Pu}$. 
TABIE 8. Organ dOBes for mixed TRU nuclides aged 6 mo and 100 y relative to 239

Pu doses.

Assumed TRU mixtures

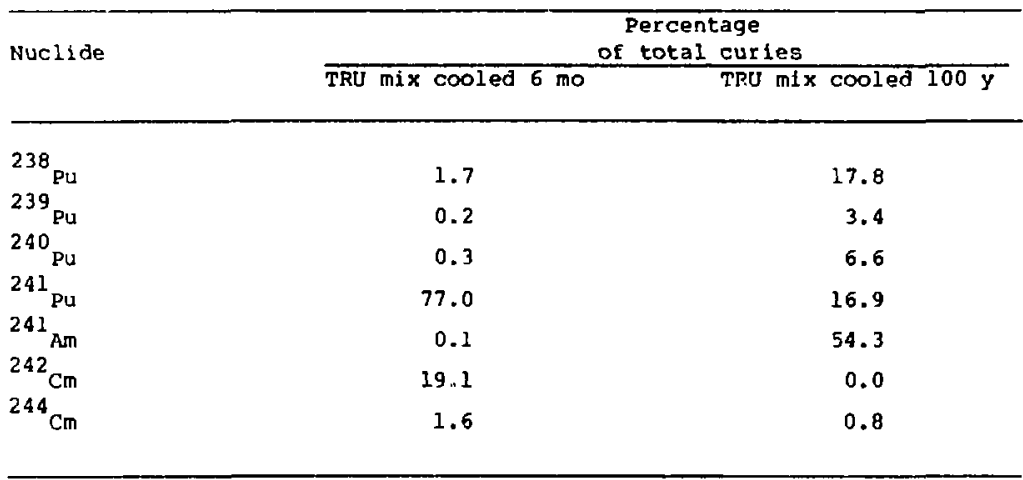

Accumulated lung dose, rem/nC1 inhaled (30-day exposure, 10- $\mu m$ particles) Year $\quad{ }^{239} \mathrm{Pu} \quad$ TRU mix cooled 6 mo TRU mix cooled $100 \mathrm{y}$

$\begin{array}{rlll}1 & 0.06 & 0.01 & 0.05 \\ 5 & 0.14 & 0.03 & 0.16 \\ 10 & 0.15 & 0.03 & 0.17 \\ 15 & 0.16 & 0.03 & 0.27 \\ 20 & 0.16 & 0.03 & 0.17 \\ 30 & 0.16 & 0.03 & 0.17 \\ 40 & 0.16 & 0.03 & 0.17 \\ 50 & 0.16 & 0.03 & 0.17\end{array}$


TABLE. B. (cont'd.)

Accumulated bone dose, rem/nCi tnhaled (30-day exposure, 10- $\mathrm{mm}$ particles)

\begin{tabular}{llll}
\hline Year & $239 \mathrm{pu}$ & TRu mix cooled $6 \mathrm{mo}$ & $\begin{array}{c}\text { TRU mix cooled } \\
100 \mathrm{Y}\end{array}$ \\
\hline 1 & $4.3 \times 10^{-4}$ & $8 \times 10^{-4}$ & $4 \times 10^{-3}$ \\
5 & 0.03 & $8 \times 10^{-3}$ & 0.03 \\
10 & 0.07 & $5 \times 10^{-3}$ & 0.07 \\
20 & 0.17 & $7 \times 10^{-3}$ & 0.11 \\
30 & 0.26 & $8 \times 10^{-3}$ & 0.14 \\
40 & 0.34 & 0.012 & 0.21 \\
\hline 0 & 0.42 & 0.015 & 0.33 \\
\hline
\end{tabular}


Calculations Indicated that the reclamation scenario dictated the most regtrictive interface concentrations between LLW and HLW. We also found that ${ }^{239} \mathrm{Pu}$ could reasonably be used as the reference isotope in the reclamation scenario.

The inter face concentration for each isotope was then normalized to a relative hazard index (RHI) to present the results in a concise format. The RHT is defined by the equation:

$$
\mathrm{RHI}=\frac{\mathrm{DC}}{\rho \text { MPC }_{\mathbf{a}}} \text {, }
$$

where $C$ is the concentration of the nuclide in the soil (i.e., 1/30 of the permitted peak concentration in the waste container). D is the average dust loading in the respirable air $\left(\mathrm{mg} / \mathrm{m}^{3}\right)$ and $\rho$ is the bulk density of the soil.

The use of the RHI allows the relative risk of a radioactive species to be described by a single number.

The reclamation scenario assumes that exposure occurs only after institutional control of the facilities has ended. Since institutional control would be maintained for 100 to 300 y after closure of the burial facilities, credit can be taken for the radioactive decay of the short-lived nuclides during that period. Calculations based on these assumptions indicate that the accident scenario can give the most restrictive interface concentrations for those isotopes with short half-lives. 
Predicted doses resulting from the scenarios discussed in the previous section were calculated and the results are sumarized in Fig. 8. Appendixes $H$ and $I$ present detailed discussion of the calculations. A general discussion follows.

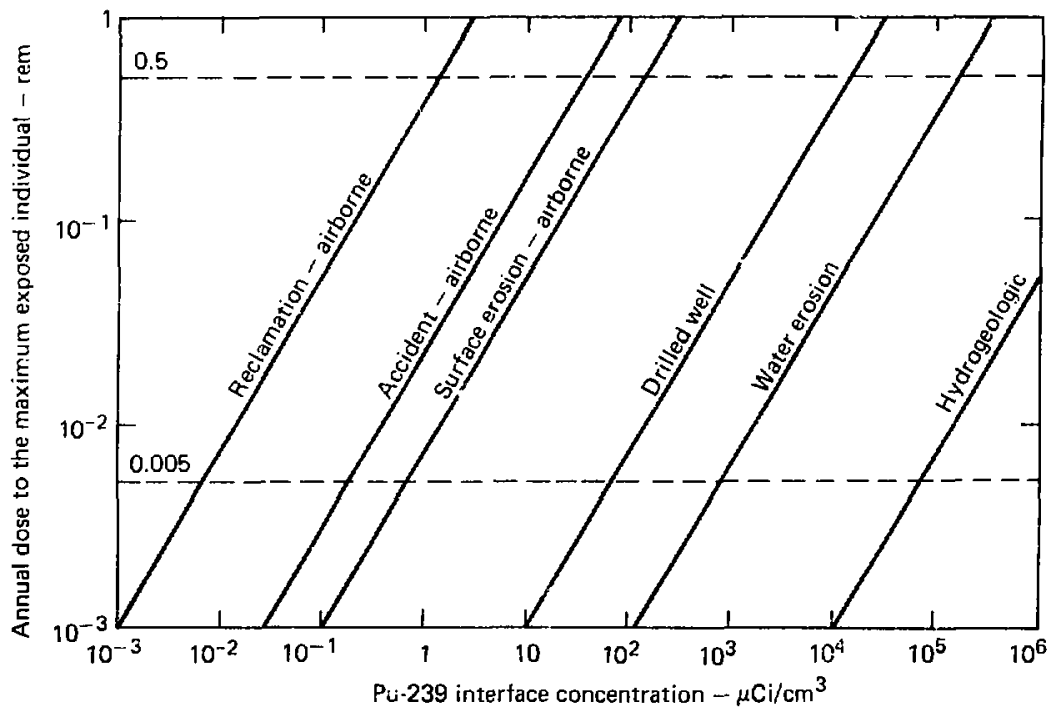

FIG. 8. Annual individual dose Vs HLW/LWW interface concentrations for ${ }^{239} \mathrm{Pu}$ calculated for six exposure scenarios. 
The eventual reclamation and reuse of the disposal site after institutional controls ace removed dictates the most restrictive LLW/HLW interface concentrations. ${ }^{239} \mathrm{Pu}$ is one of the most restrictive isotopes in the inhalation scenarios studies. Interface concentrations for other isotopes except ${ }^{129} \mathrm{I}$ were determined by normalizing the ${ }^{239} \mathrm{Pu}$ interface concentration by the MPC for ${ }^{239}$ Pu and multiplying by the MPC for the other isotopes. ${ }^{129} \mathrm{I}$ is discussed under "Ingestion Scenarios" below.

Since the reclamation scenario applies orily to the period following loss of administrative control of the burial site (100 to $300 \gamma$ after closure), radioactive decay is taken into account only for isotopes with short half-lives. There is a limit, however, in considering the decay because the near-term accident scenario becomes the major restriction at higher concentrations of the short-lived isotopes.

The HLW/LLW interface concentrations for individual radionuclides are shown in Table 9. A concentration of $1 \mu \mathrm{Ci} / \mathrm{cm}^{3}$ of ${ }^{239} \mathrm{Pu}$ in the waste container at the time of burial results in about $0.5 \mathrm{rem} / \mathrm{y}$ exposure to an individual worker in the reclamation scenario. In the accidental release scenakio, a concentration of $1 \mu \mathrm{Ci} / \mathrm{cm}^{3}$ in the waste container results in a maximum individual dose $c \dot{i} 0.01 \mathrm{rem} / y$ to an off-site resident.

\section{INGESTION SCENARIOS}

For the waterborne scenarios, the HLW/LLW interface concentrations were less restrictive than for the airborne scenarios. However, this does not hold for $129 \mathrm{I}$. 
TABLE 9. Single radionuclide HLW/LLW interface concentration values (ariuster for 100 y decay).

\begin{tabular}{|c|c|c|c|c|}
\hline Nuclide & $\begin{array}{c}\text { Halt-life, } \\
y\end{array}$ & $\begin{array}{l}\mathrm{MPC}^{\star}, \\
\mu \mathrm{Cl}_{1} / \mathrm{ml}\end{array}$ & $\begin{array}{c}\text { Interfac } \\
\text { concentrat } \\
\mu \mathrm{Ci} / \mathrm{cm}^{3}\end{array}$ & ion, \\
\hline${ }^{3} \mathrm{H}$ & 12.33 & $2 \times 10^{-7}(S, I)^{\star \star}$ & $2 \times 10^{7}$ & (Note b) \\
\hline${ }^{51} \mathrm{Cr}$ & 0.075 & $8 \times 10^{-8}$ & $6 \times 10^{6}$ & (Note $b$ ) \\
\hline${ }^{54} \mathrm{Mn}$ & 0.86 & $1 \times 10^{-9}(5,1)$ & $2 \times 10^{6}$ & (Note b) \\
\hline${ }^{55} \mathrm{Fe}$ & 2.7 & $3 \times 10^{-8}(I)$ & $2 \times 10^{6}$ & (Noce $b$ ) \\
\hline${ }^{60} \mathrm{Co}$ & 5.27 & $3 \times 10^{-10}(\mathrm{I})$ & $2 \times 10^{4}$ & (Note b) \\
\hline${ }^{59} \mathrm{Ni}$ & $8 \times 10^{4}$ & $2 \times 10^{-8}(s)$ & $3.4 \times 10^{5}$ & \\
\hline${ }^{63} \mathrm{Ni}$ & 100 & $2 \times 10^{-9}(s)$ & $6.7 \times 10^{4}$ & \\
\hline${ }^{90} \mathrm{Sr}$ & 29 & $310^{-11}$ (s) & $2 \times 10^{3}$ & (Note b) \\
\hline${ }^{90} Y$ & 0.007 & $3 \times 10^{-9}(1)$ & $2 \times 10^{5}$ & (Note b) \\
\hline${ }^{99} \mathrm{TC}$ & 213 & $2 \times 10^{-9}$ & $4.6 \times 10^{4}$ & \\
\hline${ }^{106} \mathrm{Ru}$ & 1.010 & $2 \times 10^{-10}(I)$ & $2 \times 10^{4}$ & (Note b) \\
\hline${ }^{129} I$ & $1.59 \times 10^{7}$ & $2 \times 10^{-11}$ & 1.8 & (Note d) \\
\hline${ }^{134} \mathrm{Cs}$ & 2.06 & $4 \times 10^{-10}$ & $2 \times 10^{4}$ & (Note b) \\
\hline${ }^{137} \mathrm{Cs}$ & 30.1 & $5 \times 10^{-10}(\mathrm{I})$ & $4 \times 10^{4}$ & (Note b) \\
\hline${ }^{232} \mathrm{Th}$ & $1.4 \times 10^{10}$ & $1 \times 10^{-12}(S, I)$ & 17 & \\
\hline${ }^{235} \mathrm{U}$ & $7.04 \times 10^{8}$ & $4 \times 10^{-12}(I)$ & 68 & \\
\hline${ }^{238} \mathrm{U}$ & $4.5 \times 10^{9}$ & $3 \times 10^{-12}(\mathrm{~S})$ & 50 & ? \\
\hline${ }^{237} \mathrm{~Np}$ & $2.14 \times 10^{6}$ & $1 \times 10^{-13}(\mathrm{~S})$ & 1.7 & \\
\hline
\end{tabular}




Nuclide Half-life,
$y$$\quad \begin{array}{cc}M^{*} & \begin{array}{c}\text { Interface } \\ \text { concentration, } \\ \mu C i / \mathrm{cm}^{3}\end{array}\end{array}$

\begin{tabular}{|c|c|c|c|c|}
\hline $238 \mathrm{Pu}$ & 87.8 & $7 \times 10^{-14}(\mathrm{~s})$ & 2.6 & \\
\hline${ }^{239} \mathrm{Pu} \mathrm{a}$ & $2.439 \times 10^{4}$ & $6 \times 10^{-14}(5)$ & 1.0 & \\
\hline $241_{\mathrm{Pu}}$ & 15 & $3 \times 10^{-12}$ & 130 & (Note $c$ ) \\
\hline $241_{A m}$ & 433 & $2 \times 10^{-13}(\mathrm{~s})$ & 4.0 & \\
\hline${ }^{242} \mathrm{~cm}$ & 0.45 & $4 \times 10^{-12}$ & $3 \times 10^{2}$ & (Note b) \\
\hline $244 \mathrm{~cm}$ & 17.9 & $3 \times 10^{-13}$ & 24 & (Note b) \\
\hline (Note e) & - & $1 \times 10^{-10}$ & $1.7 \times 10^{3}$ & \\
\hline (Note f) & - & $2 \times 10^{-14}$ & 0.33 & \\
\hline
\end{tabular}

\section{Notes}

Erom 10CFR20. ${ }^{\text {*t }}$ s (soluble), I (insoluble).

a. Bases from which other numbers were derived.

b. Interface concentration limited by accident scenario.

c. Based on ingrowth of daughters.

d. Based on the well-water scenario.

e. Any other single nuclide, not listed above, with decay mode other than alpha emission or spontaneous fission.

f. Any other single nuclide, not listed above, that decays by alpha emission or spontaneous $\mathrm{f}$ ission.

Because ${ }^{129}$ I has a long half-life and essentially no sorption in the soil, the well-water scenario limits the interface concentration of this isotope to $1.8 \mathrm{\mu Cj} / \mathrm{cm}^{3}$ in the buried waste. 
To indicate the $r$ isk for a given nuclide and its interface value (Table 9), we must define the RHI in terms of the corresponding MPC ${ }_{a}$, since the potential effects of airborne releases were shown to be generally more ser ious than those from waterborne releases. For ${ }^{239} \mathrm{Pu}$ the $\mathrm{RHI}$ is equal to $1.7 \times 10^{4}$ if we assume a density of $2 \mathrm{~g} / \mathrm{cm}^{3}$

We based our interface values on the releases of ${ }^{239} \mathrm{Pu}$. Interface levels for other nuclides have been normalized to that of ${ }^{239}$ Pu by use of une appropriate MPC values. Use of the MPCs assumes that they were uniformly determined, and that they can adequately serve as relative indicators of $r$ isk for the nuclides involved.

Figure 9 is a representation of the waste classification system in the RHI format. This figure also shows how the radioactive half-life is considered.

The HLW/LLW interface concentrations are suitably increased to account for radioactive decay, depending on the delay between the end of burial operations and reclamation of the land for construction. Delays of 100, 200, and $300 y$ were assumed. For half-lives greater than a few kunöred years, radioactive decay is not considered in determining the longevity of the hazard, since the conservative assumption is made that these nuclides will exist forever.

The most restrictive scenario (eventual reclamation of the land) provides the basic HLW/LIW interface. However, the accident scenario becomes the most restrictive for short half-life materials because the accident is assumed to occur before there is any significant radioactive decay.

For mixtures of nuclides in the wastes, the relative hazard indices can be weighted as indicated in 10CFR 20. "That is, the cumulative hazard index can be found by adding up the concentration-to-MPC ratios of the individual nuclides multiplied by their dust-loading corrections. Appendix $J$ gives details and examples of the use of this system.

For the interface between innocuous and low level waste, further study is required to provide a precise and defensible value. 


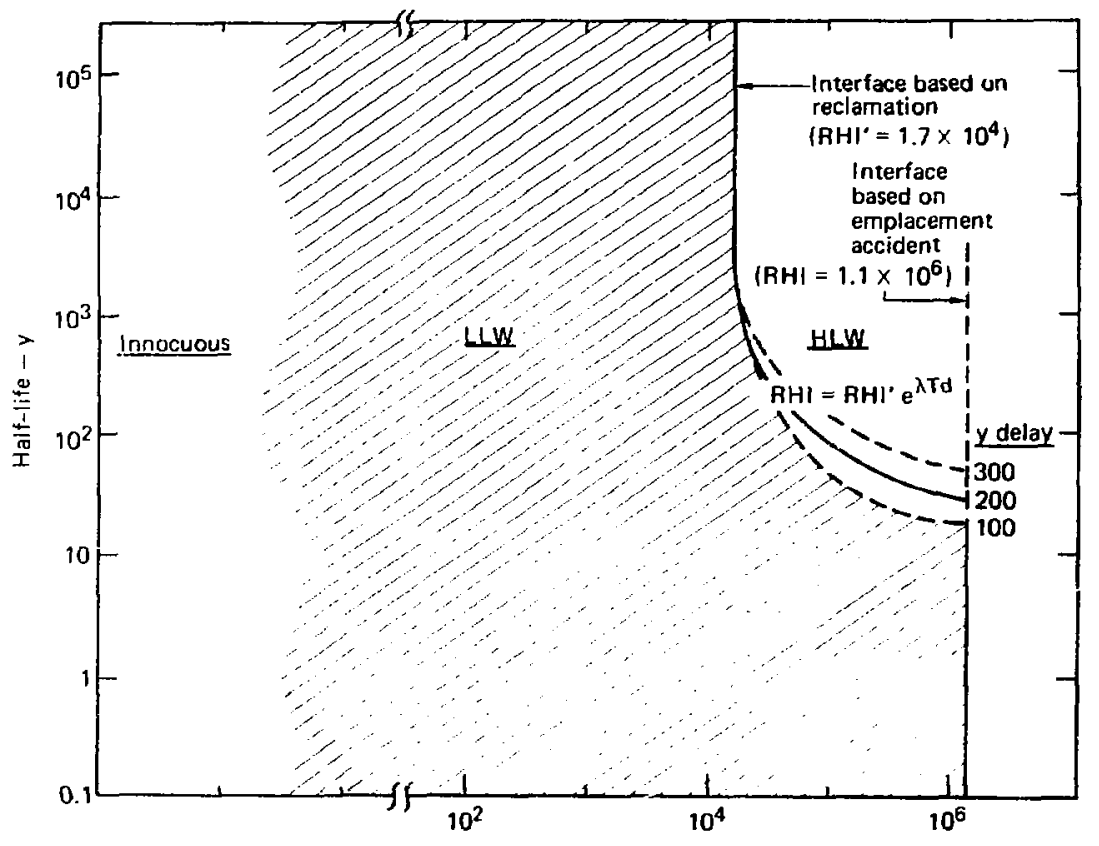

Relative hazard index (RHI) at time of emplacement

FIG. 9. Waste classification system in relative hazard index format. 
Pigure 10 presents the results of cost-benefit calculations performed to evaluate the cost effectiveness of shallow land burial vs repository isolation as a function of HLW/LLW interface level.

Given the projected waste quantities and costs in Appendix G, we can determine the cost effectiveness vs interface level. Increasing the interface levell makes additional quantities of waste acceptable for disposal as LLW at a lower cost than that of isolation. However, the $r$ isk in terms of population dose would incraase. For example, the firs' projected category of waste higher in concentration than routine LLW would contain $1000 \mathrm{ci} / \mathrm{m}^{3}$ of gross activity. The generation of $1.0 \mathrm{GWe}-\mathrm{y}$ of nuclear power would produce $75 \mathrm{~m}^{3}$ of 1000 $\mathrm{Ci} / \mathrm{m}^{3}$ waste. For a marginal cost of $\$ 3400 / \mathrm{m}^{3}, \$ 255,000 /$ GWe-y could be saved by handling this waste as LLW rather than sending it to the repository. Alternatively, it would cost $\$ 3400 / \mathrm{m}^{3}$ more to send it to a repository, but there would be a concomitant decrease in potential risk from this volume of waste.

If the HLW/LLW interface level were to be established solely on the basis of cost-benefit analysis, rather than at a cost effectiveness of $\$ 1000 / m a n-r e m$, the level would be set at about $60,000 \mathrm{Ci} / \mathrm{m}^{3}$. Such concentrations are higher than we would get if HLW were simply treated as LLW and placed in a shallow land burial facility. Thus, the cost-benefit approach does not yield a limiting upper concentration interface. Although not as restrictive an indicator of the relative hazards as are the maximum individual dose approaches, cost-benefit analysis provides useful insight and perspective on the waste management question. Assuming the Appendix I of 10CFR50 ${ }^{7}$ value of $\$ 1000 /$ man-rem as an indicator of acceptability, the interface levels suggested in this study would fall well within ALARA guiaelines. The incremental cost effectiveness of reducing the interface beyond $1.0 \mathrm{\mu Ci} / \mathrm{cm}^{3}$ would be about $10^{8} \mathrm{~s} / \mathrm{man}-\mathrm{rem}$. 


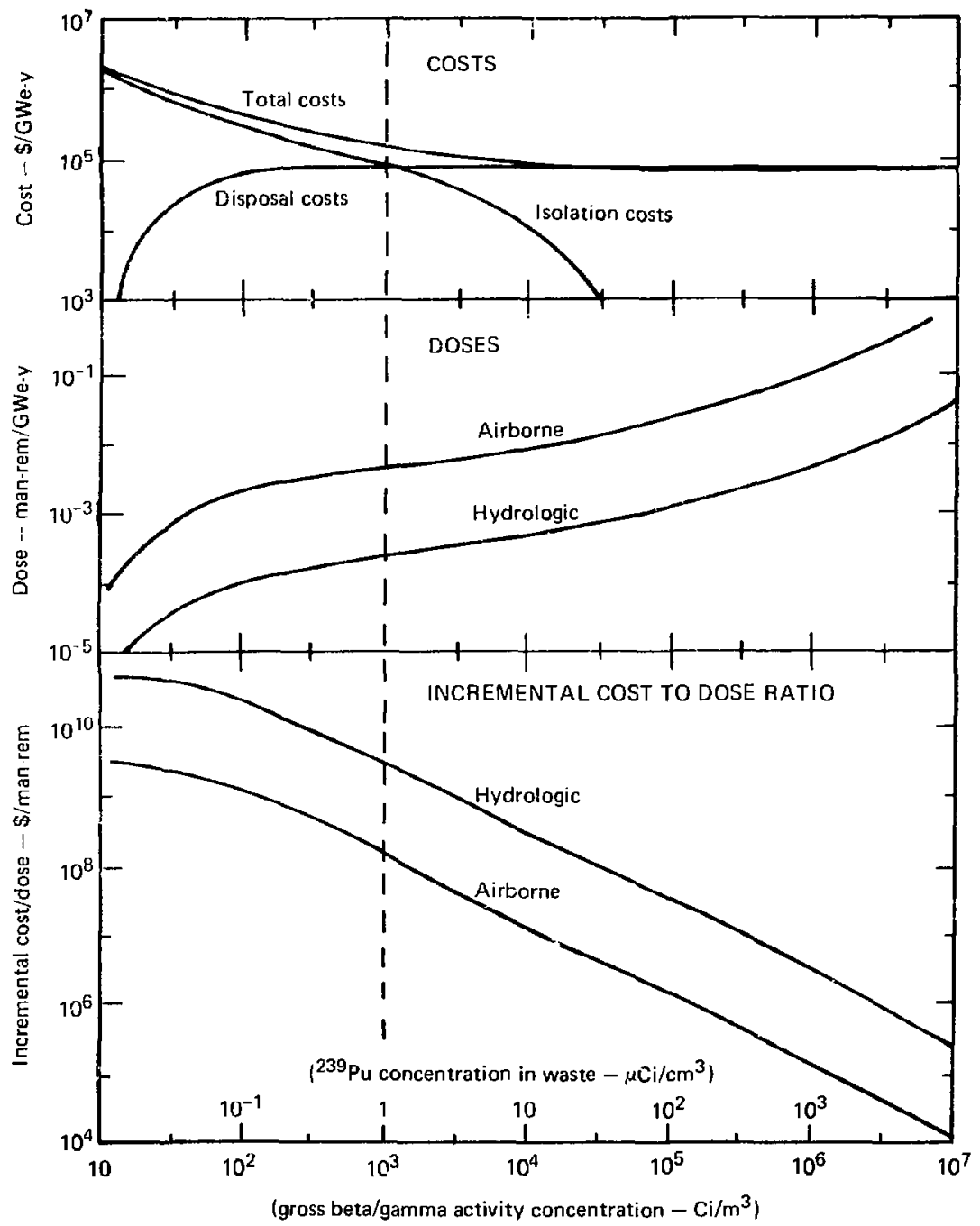

HLW/LLW interface level

FIG. 10. Cost-benefit analysis results. 
REFERENCES

1. W. C. King and J. J. Cohen, Interim Report to the Nuclear Regulatory Commission on Radioactive Waske Management, Lawrence Livermore Laboratory, Livermore, Calif., Report UCID-17497 (1977) .

2. U.S. Energy Research and Development Administration, Alternatives for Managing Wastes from Reactors and Post-Fission Operations in the LWR Fuel Cycle, washington, D.C., Report ERDA 76-43, Vol. I (1976).

3. J. 0 . Plomeke and $C$. $\mathbf{H}$. Kee, Projections of Nuclear Wastes to be Generated, Oak Ridge National Laboratory, Oak Ridge, Tenn., Report ORNL-6875 (1976).

4. International Commission on Radiological Protection (ICRP), Report of Committee on Permissible Dose for Internal Radiation, ICRP Publ. 2 (Pergarmon Press, London, 1959).

5. National Council on Radiation Protection and Measurements (NCRP), Basic Radiation Protection Criteria, washington, D.C., NCRP Report No. 39 (1971).

6. Code of Federal Regulations, Standards for Protection Against Radiation Title 10, Part $20(10 \mathrm{CFR} 20)$, U.S. Nuclear Regulatory Commission (Nov. 1960).

7. Code of Federal Regulations, Licensing of Production and Utilization Facilities, Title 10, Part 50 (10CFR5), Appendix I, "Numerical Guides for Design Objectives and Limiting Conditions for Operation To Meet the Criterion 'As Low as Reasonably Achievable' for Radioactive Material in Light-Water-Cooled Nuclear Power Reactor Effluents" (Dec. 1975).

8. W. A. Rodger, Critical Evaluation of the Limits of Transuranic Contamination of Low Level Waste, Nuclear Safety Associates, Bethesda, Md. (1975).

9. B. L. Cohen, The Hazards of Plutonium Dispersal, Institute for Energy Analysis, Oak Ridge, Tens. (1975). 
10. U.S. Nuclear Regulatory Commission, Washington, D.C., NRC Task Force Report on Review of the Federal/State Program for Regulation of

Commercial Low-Level Radioactive Waste Burial Grounds, Feport NUREG-0217 (1977).

1.. International Commission on Padiological Protection, The Metabolism of Compounds of plutonium and other Actinides, Report ICRP-19.

12. International Commission on Radiological Protection Report of the Task Group on Reference Man, Report ICRP-23 (1974).

13. T. J. Powell, D. S. Myers, J. R. Par lugreco, and G. L. Hazin, AERIN - A Computational Version of the ICRP Lung Model, Lawrence Livermore Labor ator $y$, Livermore, Calif., Report UCID-17000 (1977). 


\section{APPENDIX A}

ROSTER OF MEMBERS AND PARTICIPANTS OF THE PHASE I TECHNICAL ADVISORY PANEL

Gary R. Bray

Science Applications, Inc.

McLean, VA 22101

Art Carson

General Electric Company

San Joge, CA 94125

Jerry J. Cohen

University of California

Lawrence Livermore Laboratory

Livermore, CA 94550

Frankie Deisher

Science Applications, Inc.

McLean, VA 22101

Paul R. Eenske

Desert Research Institute

University of Nevada

Reno, NV 89507

Steve Garner

Nuclear Engineering Company

Louisville, KY 40222

Jack Healy

Los Alamos Scientific Laboratory

Los Alamos, NM $\mathbf{8 7 5 4 5}$

William Holcomb

U.S. Environmental Protection Agency

Washington, DC 20460

Donald Jacobs

Oak Ridge National Laboratory

Oak Ridge, TN 37830

Sara K. Julin

Science Applfcations, Inc.

McLean, VA 22101

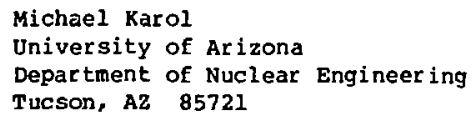

Michael Karol

University of Arizona

Department of Nuclear Engineering

Tucson, A2 85721

Hugh Kendrick

Sclence Applications, Inc.

McLean, VA 22101

William c. King

University of California

Lawrence Livermore Laboratory

Liverliore, CA 94550

James Malaro

U. S. Nuclear Regulatory Commission office of Nuclear Materials safety and safeguards

Washington, DC 20555

G. Lew is Meyer

U.S. Environmental Protection Agency Washington, DC 20460

R. I. Newman

Allied-General Nuclear Services

Barnwell, SC 29812

E. D. North

Nuclear Fuel Services

Silver Spring, MD 20902

Roy G. Post

University of Arizona

College of Engineering

Department of Nuclear Engineering

Tucson, AZ 85721 
John E. Razor

Nuclear Engineering Co.

Morehead, KY 40351

Walton A. Rodger

Uuclear Safety Associates

Bethesda, MD 20016

Harvey F. Soule

U,S. Department of Energy

Division of Nuclear Fuel Cycle and Production

Washington, DC 20545

Art ToY

Lawrence Livermore Laboratory

Livermore, CA 94550
Verne Trevorrow

Argonne National Laboratory

Argonne, IL 46309

Bruce Wachholz

U.S. Department of Energy

Division of Biological Environmental

Research

Washington, DC 20545

R. F. Willians

Electric Power Research Institute Palo Alto, CA 94303 


\section{APPENDIX B}

ROSTER OF MEMBERS AND PARTICIPANTS OF THE PHASE 2 TECHNICAL ADV ISORY PANEL

John Adam

U.S. Nuclear Regulatory Comnission office of Nuclear Materiaj.s Safety and Saf eguards

Washington, DC 20555

Bob Boland

U.S. Energy Research Development

Administration

Nevada Operations offise

Las Vegas, NV B9114

M. O. Cloniger

Battelle Pacific Northwest Laboratory

Richland, WA 99352

Jerry J. Cohen

University of California

Lawrence Livermore Laboratory

Livermore, CA 94550

J. Stewart corbett

Chem-Nuclear Systens, Inc.

Bellevue, Wh 98009

R. L. Frendberg

Nuclear Safety Associates

Rerhesda, MD 20016

William Holcomb

Environmental Protection Agency

Washington, DC 20460

William C. King

University of California

Lawrence Livermore Laboratory

Livermore, CA 94550

Paul Macbeth

Ford, Bacon \& Davis Utah, Inc.

Salt Lake City, UT B4log

Bruce Mann

U.S. Environnental protection Agency

Las Vegas, NV 89114
D. E. Michels

EG\&G, Inc.

Idaho Falls, ID $8340 \mathrm{l}$

R. I. Newman

Allied Chemical Nuclear Services

Division

Morristown, NJ 07960

Roy G. Post

University of Arizona

College of Engineering

Department of Nuclear Engineering

Tucson, A2 85721

Walton A. kodger

Nuclear Safety Assoriates

Bethesda, MD 20016

Vern Rogers

Ford, Bacon \& Davis Utah, Inc.

salt take City, uT 84108

Harvey F. Soule

U.S. Energy Research and Development Administration

Division of Nuclear Fuel Cycle and Production

Washington, DC 20545 


\section{APPENDIX $C$ \\ PREVIOUSLY PROPOSED RADIOACTIVE-WASTE CLASSIFICATION SYSTEMS}

Several waste classification (WC) systems have been proposed during the past few years. A review of these systems follows.

\section{IAEA RADIOACTIVE-WASTE CATEGORIES}

The IAEA (1967) tabulated information from 11 countries on their WC systems. Cl It was found that no two countries have the same classification system and that some countries use more than one system.

The IAEA system categorizes the waste as liguid, solid, or gaseous, with each rategory broken down as described below.

\section{Liquid Wastes}

The subclassification under liquid wastes is based on activity concentration levels as follows:

Category Activity livel, A, $\mu \mathrm{Ci} / \mathrm{ml} \quad$ Remarks

$\begin{array}{lll}1 & A<20^{-6} & \text { Not normally treated } \\ 2 & 10^{-6}<A \leq 10^{-3} & \text { Without shielding } \\ 3 & 10^{-3}<A \leq 10^{-1} & \text { Shielding possible a } \\ 4 & 10^{-1}<A \leq 10^{-4} & \text { Shielding necessary } \\ 5 & 10^{4}<A & \text { Cooling necessary }\end{array}$

Treatment is by usual methods (i.e., evaporation, ion-exchange, or chemical treatment). 
In the solid-waste category, there are three considerations, as follows:

- For strong beta and gamma enitters, the surface dose rate is the controlling Eactor.

- For strong alpha emitters, the activity per volume $\left(\mathrm{Ci} / \mathrm{m}^{3}\right)$ controls.

- For large amounts of fissile materials, additional packing requirements, such as IAEA "Regulations for the safe Transport of Radioactive Materials," are controlling.

For the three considerations, the following classification is suggested:

Radiation dose, $D$, on

Category surface of wastes, R/hr Remarks

$\begin{array}{lll}1 & \mathrm{D} \leq 0.2 & \beta-\gamma \text {-emitters dominant; } \\ 2 & 0.2<\mathrm{D} \leq 2 & \alpha \text {-emitters are insignificant } \\ 3 & 2<\mathrm{D} & \alpha \text {-emitters dominart; } \\ 4 & \alpha \text { activity expressed } & \beta-\gamma \text {-emitters insignificant; } \\ & \text { in ci/m } & \text { criticality is no problem }{ }^{\mathrm{a}}\end{array}$

${ }^{\text {If }}$ criticality is a matter of concern with the waste, it is assumed that the solid wastes are treated or packaged or both to prevent criticality; it is also suggested that $\mathrm{Pu}$ and $\mathrm{U}$ wastes are potentially retrievable and may be separated for economic reasons. 
The basic consideration for classifying gaseous wastes is activity level expressed in $\mathrm{Ci} / \mathrm{m}^{3}$ :

$\begin{array}{lll}\text { Category } & \begin{array}{c}\text { Activity level, } \\ \mathrm{A}, \mathrm{Ci} / \mathrm{m}^{3}\end{array} & \text { Remarks } \\ 1 & \mathrm{~A} \leq 10^{-10} & \text { Effluents not usually treated. } \\ 3 & 10^{-10}<\mathrm{A} \leq 10^{-6} & \text { Effluents usually treated by filtration. } \\ 10^{-6} \leq \mathrm{A} & \begin{array}{l}\text { Effluents usually treated by methods } \\ \text { other than filtration. }\end{array}\end{array}$

\section{Discussion}

Figure $\mathrm{Cl}$ is a diagram of the IAEA waste classification system. The following waste characteristics must be known for this system to be used to categorize any given waste:

- Physical state (solid, liquid, gaseous).

- Activity level for $\alpha$-dominant solids, for liquids, and for gases.

- Radiation dose at the surface for $\beta-\gamma$-dominant solidis.

- Radiation type, indirectly for solias. 


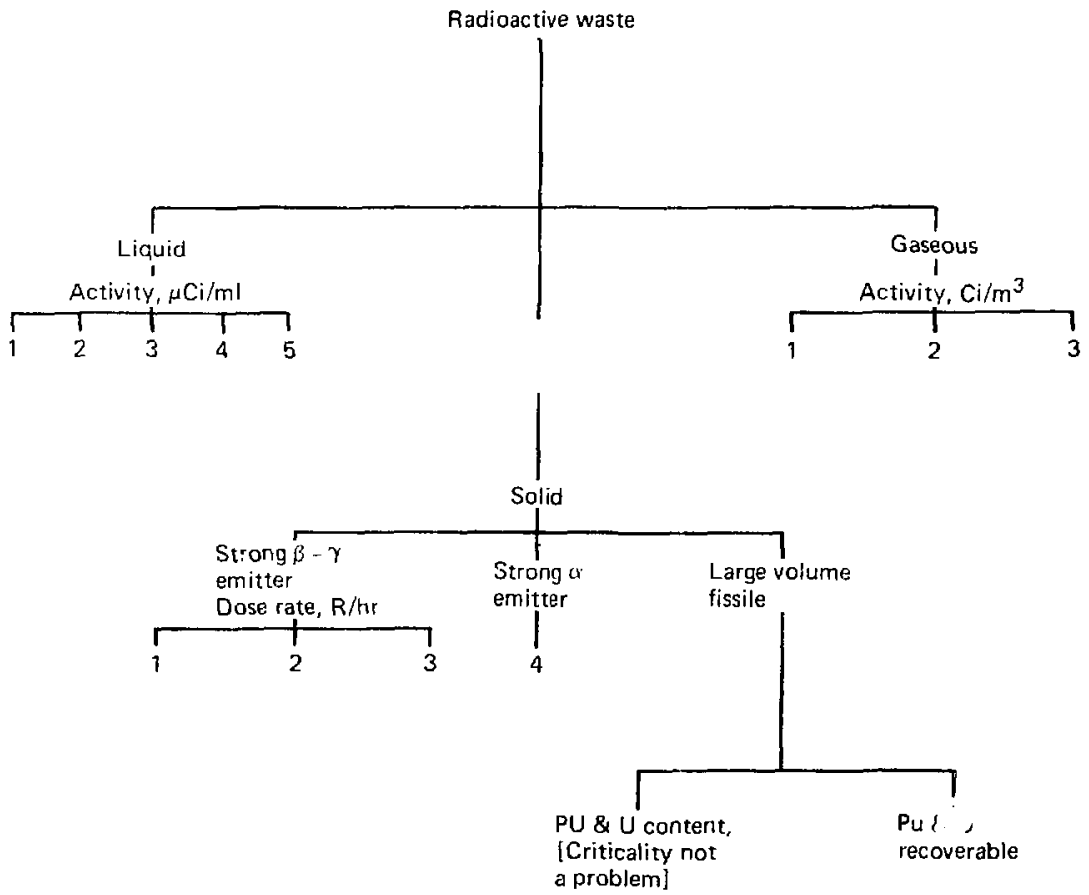

FIG. Cl. IAFA waste classification system. 
In adcition, the following comments apply:

- Compared with other systems, the IAEA system is uncomplicated.

- The expression of radioactivity in curies gives little indication of the toxicity or hazard potential.

- The categories give no guidance for disposall methors.

- The system does not consider the half-life or longevity of potential hazards.

AIChE RADIOACTIVE WASTE CATEGORIES

The waste classification system formulated under the sponsorship of the $\mathrm{AIChE}^{\mathrm{C} 2}$ is based on the following premises:

- The major parameter for classification is the "ratio of radionuclide concentration in the waste (at the time of consideration) to the MPC of the same waste constituents in water, air, or solids ${ }^{n}$ in terms of MPC, MPE, or MPQI, as recommended by the International commission on Radiological protection (ICRP).

- Wastes should be classified while they are in containment or before release. Decay during storage may result in reclassification of wastes.

- Individual radionuclide concentrations must be determined for exact categories.

- Iiquids and gases are treated as fluids; solids require further considerations.

- The smaller ICRP-MPC value should be used when MPCs are specified for different solubilities.

- Primary classification parameters do not include chemical content, physical properties, origin, total amounts of waste, half-life, or degree of natural reconcentration once released.

- Definitions proposed are intended for use to describe the characteristics of wastes in judgments involving treatment, disposal, regulatory action, and definitions of safety. 
Table cl summarizes this waste classification system. Using the table requires the following information:

- Where wastes contain mixtures of radionuclides, the ratio of nuclide concentration to MPC for example, is determined by using the MPC for known mixtures or unidentified mixtures of radionuclides as recommended by the ICRP.

- Units of MPQI/kg are used for solids because this measure is comparable to units for liquids and gases even though solids are not considered ingestible.

\section{Waste Categories}

As Table $\mathrm{Cl}$ shows, this classification system divides the waste into five major categories, Classes A, B, C, D, and E, in ascending order of rajionuclide concentrations. The following statements apply.

Class A (Population Level). Class A includes waste with radionuclide concentrations not exceeding (uncontrolled) population level MPC values. This statement should not be construed to mean that there are no restrictions on the release of these wastes to the environment other than constraints such as ALAP and ALARA.

Class B (Occupational Level). One or more of the nuclides or the mixture of radionuclides exceeds class a limits, but no radionuclide or mixture in liquid or gaseous wastes exceeds the specified MPC ( $40 \mathrm{hr} / \mathrm{wk}$ ) for normal occupational exposure and no nuclide or mixture in solid wastes exceeds specified MPQI/kg for normal occupational exposure.

Class C (Low Level). Limits on radionuclide concentrations pertain to one or more radionuclides or to a mixture of radionuclides. Treatment of some wastes in this category may convert the major fraction to a Class A or Class B waste, leaving a minor fraction of concentrated wastes. Suvclasses C-1 and C-2 are based on ICRP maximum permissible radiation exposure to the whole body. This breakdown, in many cases, would separate alpha from beta-gamma wastes. (Category $C$ is based on radionuclide content; the subcategories are based on surface radiation.) 
TABLE Cl. AIChE radioactive waste categories.

Class A (Population Level)

Liquid and gas

Solid

Surface radiation ${ }^{c}$
Iess than or equal to the maximum permissible concentration (MPC) ${ }^{a}$ for members of the population at large (including persons living in the neighborhood of controlled areas) Less tha" or equal to the maximum permissible quarterly intake (MFQI) for members of the population at large (including persons living in the neighborhood of controlled area) $\mathrm{kg}$ solid

Less than or equal to the maximum permissible whole body exposure (MPE) ${ }^{a}$ for members of the population at large (including persons living in the neighborhood of controlled areas)

\section{Class B (Occupational Level)}

Liquid and gas

Solid

Sur face radiation ${ }^{c}$
Greater than class A but less than or equal to (MPC) ${ }^{a}$ occupational exposure $(40-h r$ w $)$

Greater than Class A but less than or equal to (MPQI) ${ }^{d}$ for occupational exposure $/ \mathrm{kg}$ solid

Greater than Class A but less than or equal to $(M P E)^{C}$ for occupational exposure $e^{b}(40-h r w k)$

Class C (Low Level)

Liguid and gas

Solid

Surface radiation class $\mathrm{C}-1$
Greater than Class $B$ but less than or equal to $10^{4} \times$ Class B

Greater than Class $B$ but less than or equal to $10^{4} \times$ Class B

Less than or equal to (MPE) ${ }^{e}$ (occupational) at surface ${ }^{b}$

Class $\mathrm{C}-2$
Greater than (MPE) ${ }^{\text {e }}$ (occupational) at surface ${ }^{b}$ 
TABLE Cl. (cont'd.)

Class D (Intermediate Level)

Liquid, gas, or solid Greater than Class $C$ but iess than or equal to $10^{4} \times$ Class $\mathrm{C}$

Solid

Greater than class $C$ but less than or equal to $10^{4} \times$ Class C

Surface radiation

Class D-1

Less than or equal to (MPE) $^{e}$ (occupational) at surface

Class D-2 Greater than (MPE) ${ }^{e}$ (occupational) at surface $^{b}$

Class E (High Level)

Liquid, gas or solid Class D

Surface radiation

Class E-1

Less than or equal to (MPE) $^{\text {e }}$ (occupational) at surface ${ }^{b}$

Class $\mathrm{E}-2$

Greater than (MPE) ${ }^{e}$ (occupational) at surface ${ }^{b}$

a ICRP Publication 6 , Recommendations of the International commision on Radiological Protection, as Amended 1959 and Revised 1962, (1964), Pergamon Press.

${ }^{\text {b In the }} 1958$ report of ICRP Committee II, the recommended MPE to the gonads or the whole body is $5 \mathrm{rem} / \mathrm{y}$ for occupational exposure. For the population at large, it is assumed to be $1 / 100$ of 5 , or 0.05 , for whole body genetic effect. EApplies to surface of container, object, or pool of liquia. $\mathrm{d}_{\mathrm{MPQI}}=\left(\mathrm{MPC}_{\mathrm{w}}\right.$ for $168 \mathrm{hr}$ occupational exposure $)(2200 \mathrm{ml} / \mathrm{day}, 91$ days/guarter $)=\left(\mathrm{MPC}_{w}\right)\left(2 \times 10^{5}\right) ; \mathrm{MPC}$ applies to water

${ }^{e}$ Section $C$ of Radiation Protection-Recommendations of the International Commission on Radiological protection (adopted September 9, 1958) (Pergamon Press, Iondon, 1959) (ICRP, Pub. 1). 
Class D (Intermediate Level). In general, Class D wastes will be stored for safety and decay purposes, or converted to or incorporated in solids for ultimate disposal. (Incorporation into organic matrix or cement before disposal is considered for Class D wastes.) Subcategories are defined similarly to Clans C subcategorles.

Class E (High Level). These wastes usually will be stored for safety and decay purposes, or converted or incorporated into radiution-stable solids for disposal. Subcategories are similar to Class D subcategories.

\section{$\underline{\text { Discussion }}$}

Figure $\mathrm{C2}$ is a diagram of the AiChE waste classification system. Three waste characteristics must be known for this system to be used to categorize any given waste:

- Physical state (solid, liquid, gaseous).

- Radionuclide content as MPC for liquids and gases or MPQI Eor solids.

- Surface radiation as MPE for solids.

\section{Radioactive waste}

Liquids \& gases
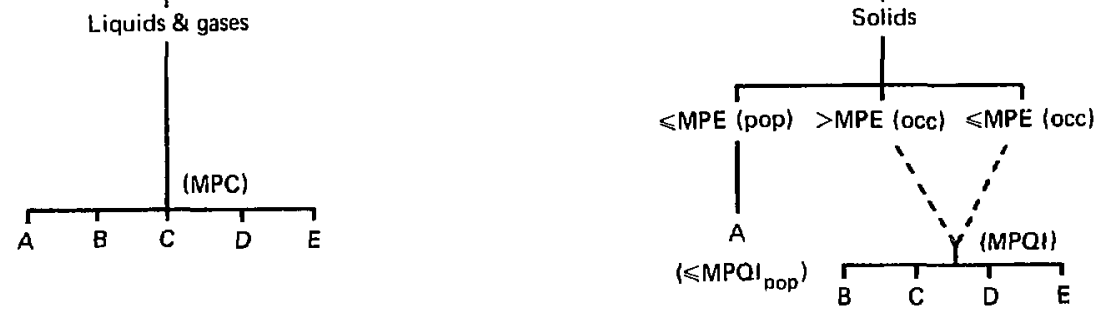

FIG. C2. AIChE waste classification system. 
The following comments also apply to this system:

- Its categories indicate potential hazards.

- It is relatively simple.

- It offers guidance for a suitable disposal method.

- It considers physical states.

- It may be operationally complicated.

- It does not consider half-lives to ascertain duration of hazard.

\section{GERA'S PROPOSED WASTE-CLASS IFICATION SYSTEMS}

Gera suggests that radioactive wastes should be classified according to the duration of required containment. ${ }^{\mathrm{C} 3}$ clear segregation of waste; requiring containent for relatively short times from those presenting a significant environmental hazard for geologic time periods would probably be sufficient. Two points that Gera makes are that ( 1 ) the destiny of the waste is a relevant classification factor, and that (2) half-lives of the radionuclides contained in the waste are a controlling element in future waste management steps. Figure $\mathrm{C} 3$ is a diagram of this proposed system.

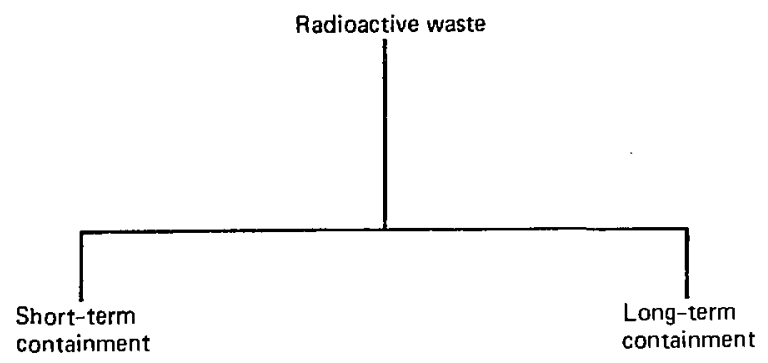

FIG. C3. Gera's classification system based on duration of containment. 
Tentative limits of concentration for long-lived ajpha emitters to be used for the segregation of solid wastes have been proposed in the United states and in France. These limits are $10 \mu \mathrm{Ci} / \mathrm{kg}$ and 10,000 time $\mathrm{MPC}_{W}$, respectively. Concentration limits mig̣ht not suffice as criteria. It may be necessary to introduce an additional limit on the long-lived activity that can be disposed of in particular burial grounds. This inventory limit should be based on the possible transfer of the radioactivity to man after abandonment of the burial ground.

\section{CLASSIFICATION SYGTEM}

Ger $a^{C 4}$ previous]y developed a rigorous waste classification system based on MPCs, activity concentrations, half-lives and expostre rates.

System

This system is described in Tables $\mathrm{C} 2, \mathrm{C} 3$, and $\mathrm{C} 4$, and diagrammed in Fig. C4. Detailed knowledge of the radionuclides and their concentrations is required for use of this system. Subsequent work on the development of a functional waste classification system led Gera to conclude that his proposed 1968 system and those comparable to it were "rather impractical and not relevant to the actual needs of waste management."

The 1968 classification system requires that the followina waste characteristics be well known: (1) physical state, (2) Mra, i;) half-life, (4) activity concentration, and (5) exposure rate. In addition, it should be noted that this system: (1) considers physical states, (2) provides guidance for disposal of waste, and (3) tends to be complex in that it requires detailed knowledge of waste composition. These attributes imply that a detailed knowledge of the radionuclide content is also availabie for each waste. 
TABIE C2. Categories of liquid and gaseous wastes proposed by Gera (1968) .

\begin{tabular}{|c|c|c|}
\hline $\begin{array}{l}\text { Categories according to } \\
\text { MPC multiplication factors }\end{array}$ & $\begin{array}{c}\text { Examples of possible } \\
\text { waste categories }\end{array}$ & $\begin{array}{c}\text { Categories according } \\
\text { to treatment }\end{array}$ \\
\hline A. < MPC & $\begin{array}{l}\text { A-1 (Discharge) } \\
\text { A-2 (Treatment; DF }<10^{3} \text { ) }\end{array}$ & $\begin{array}{l}\text { 1. No treatment; } \\
\text { discharge }\end{array}$ \\
\hline B. From MPC to $10^{3} \mathrm{MPC}$ & $\begin{array}{l}\text { B-1 (Discharge) } \\
\text { B-2 (Treatment; } D F<10^{3} \text { ) } \\
\text { B-3 (Treatment; } 10^{3}<D F<10^{6} \text { ) }\end{array}$ & $\begin{array}{l}\text { Treatment with } \\
\text { DF up to } 10^{3}\end{array}$ \\
\hline From $10^{3}$ MPC to $10^{6} \mathrm{MPC}$ & $\begin{array}{l}\text { C-1 (Discharge) } \\
\text { C-2 (Treatment; DF }<10^{3} \text { ) } \\
\text { C-3 (Treatment; } 10^{3}<D F<10^{6} \text { ) } \\
\text { C-4 (Treatment; DF }>10^{6} \text { ) }\end{array}$ & $\begin{array}{l}\text { Treatment with } \\
\text { DF between } \\
10^{3} \text { and } 10^{6}\end{array}$ \\
\hline D. From $10^{6} \mathrm{MPC}$ to $10^{9} \mathrm{MPC}$ & $\begin{array}{l}\left.D-2 \text { (Treatment; } D F<10^{3}\right) \\
\left.D-3 \text { (Treatment; } 10^{3}<D F<10^{6}\right) \\
\left.D-4 \text { (Treatment; } D F>10^{6}\right) \\
D-5 \text { (Containment) }\end{array}$ & $\begin{array}{l}\text { Treatment with } \\
\text { DF exceeding } 10^{6}\end{array}$ \\
\hline E. Greater than ? ${ }^{9} \mathrm{MPC}$ & $\begin{array}{l}\text { E-3 (Treatment; } 10^{3}<D F<10^{6} \text { ) } \\
\text { E-4 (Treatment; DF }>10^{6} \text { ) } \\
\text { E-5 (Containment) }\end{array}$ & $\begin{array}{l}\text { No treatment; } \\
\text { containment }\end{array}$ \\
\hline
\end{tabular}

Note: $\quad D F=$ Decontamination factor. 
TABLE C3. Categories of solid wastes according to activity concentration and half-life proposer by Gera (196B).

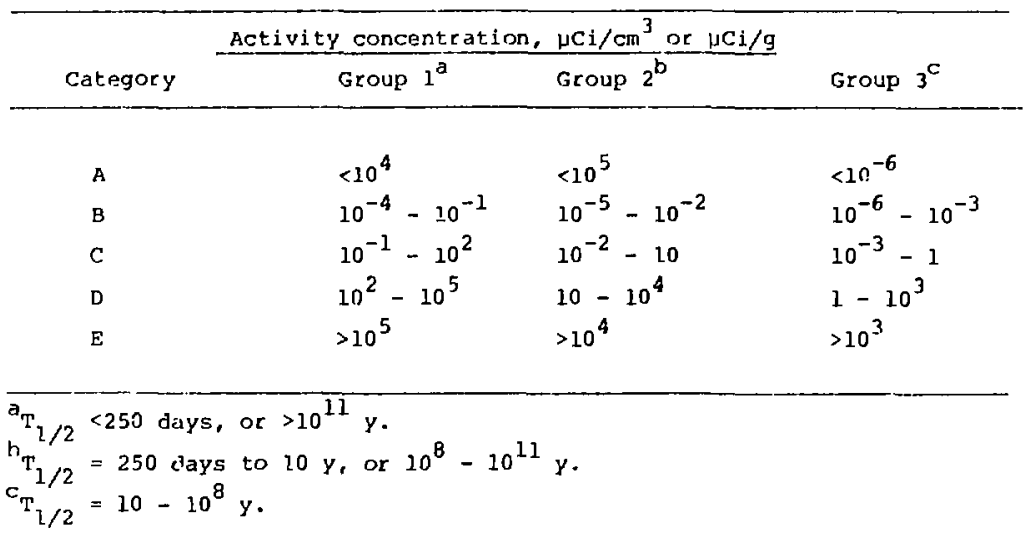


TABLE C4. Categories of solid wastes according to radiation index proposed by Gera (1968).

\begin{tabular}{|c|c|}
\hline Category & $\begin{array}{l}\text { Radiation Index } \\
i=k^{a} D^{b}\end{array}$ \\
\hline I & $<0.002$ \\
\hline II & $0.002-0.02$ \\
\hline I I I & $0.02-0.2$ \\
\hline IV & $0.2-2$ \\
\hline v & $>2$ \\
\hline $\begin{array}{c}{ }^{a} \text { Surface area of } \\
\text { perpendicular to } \\
\qquad \begin{array}{c}\text { Area } \\
<1 \mathrm{~m}^{2} \\
1-5 \mathrm{~m}^{2} \\
5-20 \mathrm{~m}^{2} \\
>20 \mathrm{~m}^{2}\end{array}\end{array}$ & $\begin{array}{l}\text { or package, } \\
\text { ion of measurement: } \\
\qquad \begin{array}{c}k \\
1 \\
3 \\
6 \\
19\end{array}\end{array}$ \\
\hline
\end{tabular}

Coefficient $k$ reflects the different attenuation of exposure rate with the distance as a function of source dimensions; the values are taken from Regulations for the Safe Transport of Radioactive Material.s, p. 69 (IAEA, 1967). $b_{D}$ is exposure rate in air in $R / h r$, measured at a distance of $1 \mathrm{~m}$ from the waste. 
Liquids \& gases
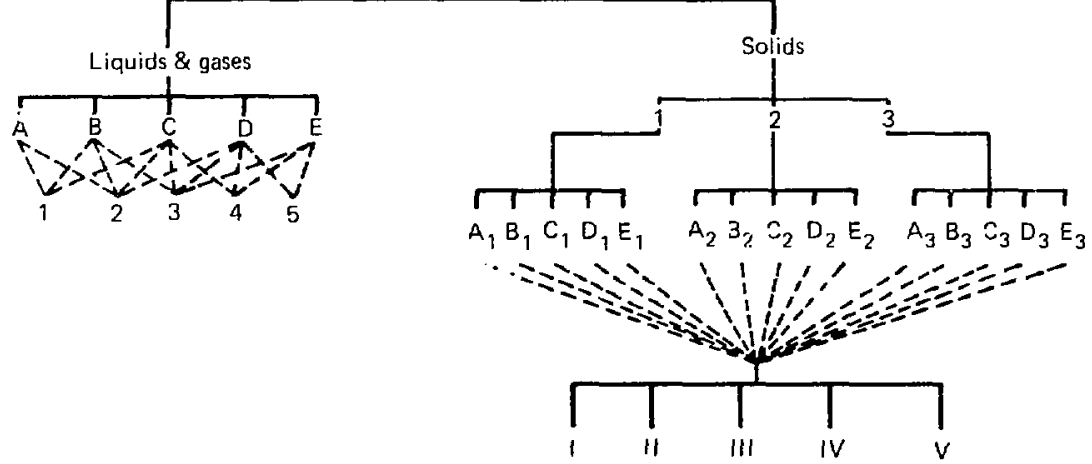

FIG. C4. Gera's 1968 waste classification system.

\section{Classification System}

Gera states that a succinct definition of the terminology in use today may constitute a sufficient classification system. His proposed definitions are as follows:

High-Level Waste. This category includes only wastes from the reprocessing of spent fuels or the spent fuels themselves. These wastes contain the bulk of the fission products and significant amounts of the long-lived alpha emitters. Liquid concentrations are in the thousands of curies per litre. Wastes are self-heating. Long-lived alpha emitters exist in concentrations too high to allow disposal for periods far exceeding the expected life of engineered storage structures.

Low-Ievel Waste. This category includes wastes with low hazard potential and with activity concentrations not much higher than MPC. Also included are large volumes that require no shielding and most of which may be treated with simple filtration or flocculation techniques, as well as solid wastes that can be handled without particular precautions.

Alpha-Bearing Waste. All wastes containing alpha emitters in excess of some appropriate threshold value are defined as alpha-bearing wastes; in particular, long-lived isotopes of transuranium elements. 
Cladding waste. This category includes cladding hulls and associated fuel assembly hardware from mechanical decladding of spent fuel. Most of the activation products and portions of the sorbed fission products and alpha emitters are present.

Intermediate-Level waste. This includes all wastes not included in the preceding categories. These wastes cannot be seleased to the environment and usually require treatment and shielding, but not cooling.

The classification system reguires a knowledge of the following waste characteristics: (1) source of the waste, (2) dominant radiation, and (3) general operational information.

It should be noted that the system (1) is simple and practical, and (2) provides guidance for the disposal of waste.

\section{ANSI RADIOACTIVE WASTE CATEGORIES}

To promote better communication on radioactive wastes between the nuclear energj industry and the public, the American National standards Institute explicitly defined the terms used to describe broad categories of wastes. 6.5 The basis for this system was a consideration of the sources of the waste in the fuel cycle and the physical nature of the radionuclides contained in the wastes. The waste categories specifically exclude (1) materials being stored for possible future recovery of radioactive contents of value, and (2) materials that are normally of use and are being stored for possible future removal of the radioactive contaminant (s). For liquid and gaseous wastes, the concepts used for specific concentrations are those of the Federal Radiation Council given in the Radioactivity Concentration Guide (RCG) * Figure C5 diagrans the ANSI waste categories.

\section{Waste Categories}

The radioactive waste categories defined below include solid waste subcategories defined by parameters independent of possible mechanisms of exposure. 


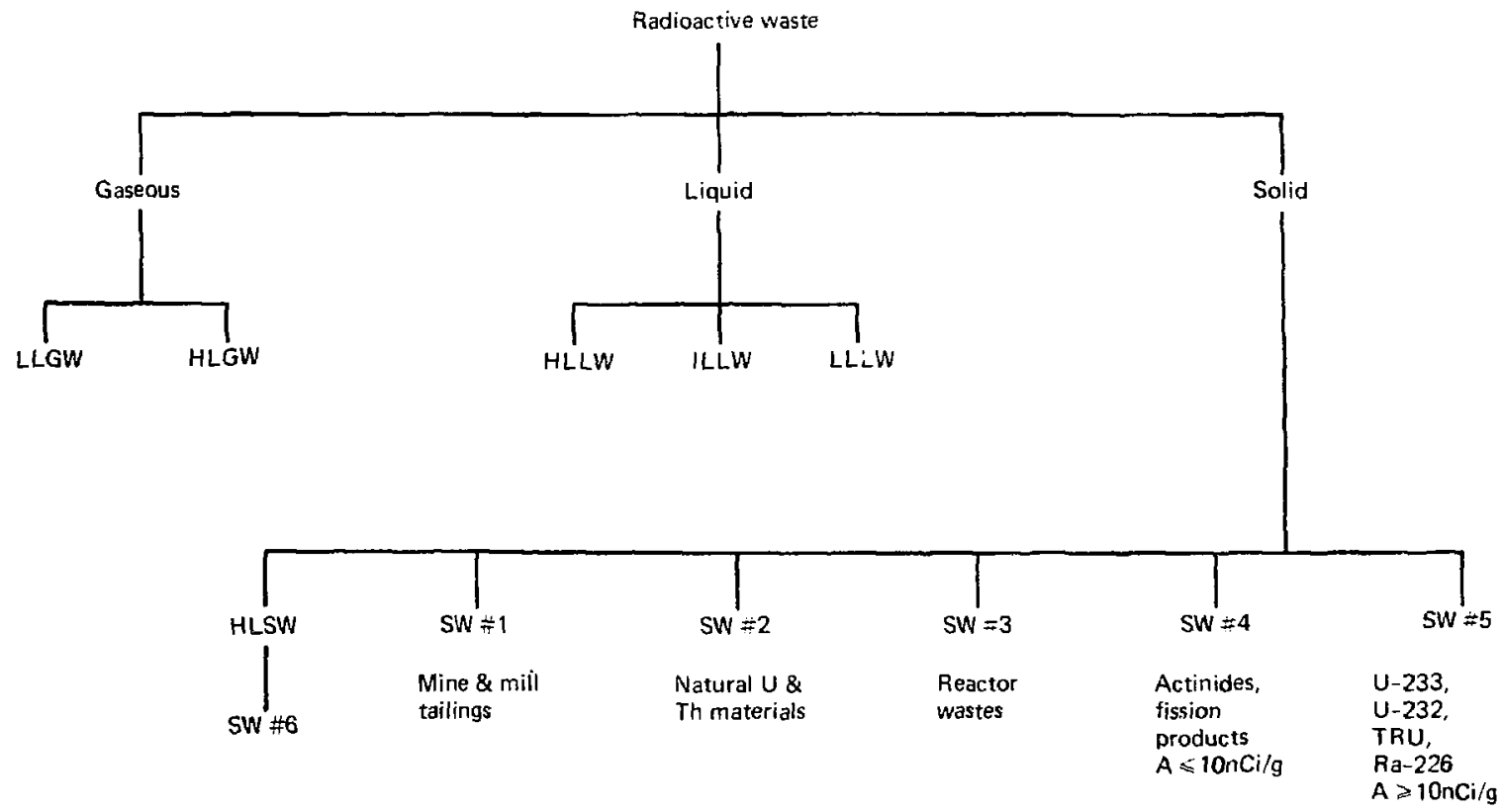

FIG. C5. American National Standards Institute waste categories. 
High-Level Solid or Liguid Haste. Included in this category are the following:

1. Aqueous waste stream from first cycle of solvent extraction, including waste strears $f$ rom subsequent cycles separate from or added to the first; solids or concentrates prepared from this first cycle and additions to it, where extraction cycles are intended for reprocessing (not including research reactors <1 MW).

2. Streams from partial separations where specific activity remains high. 3. Fuel elements fron reactors (research reactors < $1 \mathrm{MW}$ ).

Low-Level Liquid Waste. Wastes that after treatment (no more complex than filtration or ion exchange) can be released with reasonalie assurance that the concentration in the water at the point of release will be less than the RCG value for the public (weighting individual RCG values by relative abundance of radionuclides present).

Intermediate-Level Liquid Waste. Liquid wastes not included in the high-level or low-level liquid waste categories. Wastes will eventually be treated to yield a processed fraction of low-level liquid wastes and a fraction that will be added to high-level liguid wastes.

Low-Level Gaseous Waste, Gaseous materials fincluding entrained or suspended volatile material, vapors, droplets, and particulate matter) which, after treatment no more complex than conventional filtration or scrubbing, can be released as specified in the low-level liquid waste category.

High-Level (Stored) Gaseous Waste. Gasfous or volatile materials not defined in the low-level gaseous waste category, which are stored either in gaseous Eorm or sorbed in or on a solid medium.

Solid Waste. This category includes six groups:

1. Mine and mill tailings: tailings from mining or milling of uraniun or thorium ores, in which daughter products are dispersed throughout the tailings so their concentration is no higher in any significant portion of a tailings pile than it was in original ores. 
2. Natural uranium and thoriun materials: solid waste with no radiation content exceeding the usual criteria for occupational radirion safety, except for natural uranium, enriched urantum, or thorium, which are the limiting potential hazard in the handling of the wastes.

3. Nuclear reactor waste: material normally nonradloactive containing no activity except that induced by neutron or other subatomic particle capture.

4. Material containing or contaminated with fission products or other radioactive materials not defined elsewhere, such that the concentration of selected actinides is less than the mirinith concentration as stated in solid waste category 5.

5. Selected actinide waste. Material containing or contaminated with ${ }^{233} \mathrm{v},{ }^{232} \mathrm{v}$, all transurantum radionuclides and ${ }^{226} \mathrm{Ra}$ at: concentrations of $\geq 10 \mathrm{nCi} / \mathrm{g} \quad(10 \mu \mathrm{Ci} / \mathrm{kg}) . \quad\left({ }^{226} \mathrm{Ra}\right.$ is inclucted with the actinides because of its comparable properites.)

6. Solid material included in the high-level solid- or liquid-waste category with the notation that relatively small amounts of such matarials will not affect the status of solid waste category 4 or 5 (e.g., surface contamina:ion on equipment that has been in contact with high-level wastes or samples removed for analytical control purposes).

Discussion

The following waste characteristics must be known to use this system to categorize any given waste:

- Rhysical state.

- Source of the waste.

- Activity concentrations (Iiquids and gases).

- Transuranic and ${ }^{226}$ Ra concentrations.

In adation, it should be noted that the system (1) specifically excludes materials stored for future extraction of valuable material, and (2) does not provide guidance for the disposal of waste. 


\section{AEC RADIOACTIVE WASTE MANAGEMENT CIASSIFICATIONS}

The AEC classifications ${ }^{C 6}$ are intended as definitions of wastes and as terminology for AEv-assigned responsibilities, authorities, and procedures for radioactive waste managenent. The definitions do not represent a rigorous, comprehensive classification system, but do show the work done by DOE's predecessor. Figure $\mathrm{CG}_{6}$ is a diagram of the AEC waste classification system.

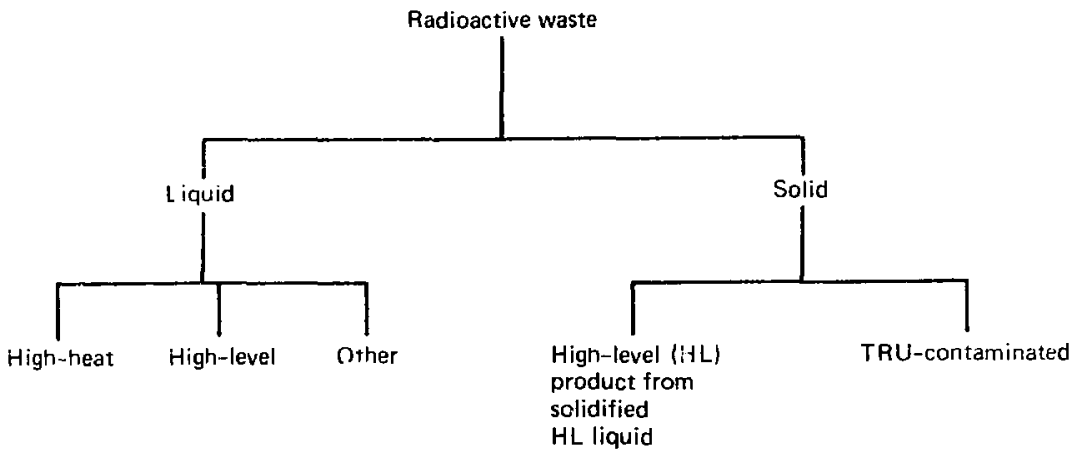

FIG. C6. AEC waste classification system.

\section{Definitions}

Radioactive wastes in general and liquid and solid wastes are defined as follows:

Radioactive Waste. Materials of no value consisting of, including, or contaminated with radioactive material in excess of the levels or concentrations permitted in AEC Property Management Instructions for unconditional release of excess property. These include: (1) stored Iiquid, solid, or gaseous residues from chenical or metallurgical processing oi radioactive materials; (2) discarded items such as defective equipment and building rubble, not radioactive in themselves but contaminated with 
radisactive materlals; and (3) discarded items containing induced

radioactivity. Treated as a separate category are (1) irradiated fuela stored for pronalble procensing, (2) radioactive scrap stored for possible recovery of ureful valung, and (3) materials and equipment stored for possible future use following drocontamination.

Liquid Radioactive Waste. Solutions, suspensions, and moblle sludges, contaminaterl with radioactive materials.

Solid Radioactive Wagte. Material that is essentially dry but may contain sorbed radioactive fluids in sufficiently small amounts to be immobile when buried in dry soil.

Waste Classes

Classifications based on these definitions are specified for comson terminology as follows:

High-Heat Liquid Waste. Liquid waste containing sufficient thermal energy to require some supplemental means of cooling, such as cooling coils.

High-Level Liquid Waste. The aqueous waste resulting from the operation of the first-cycle extraction system, or equivalent concentrated wastes from subsequent extraction cycles, or equivalent wastes from a process not using solvent extraction, in a facility for processing irradiated reactor fuels.

high-Level Waste. High-level liquid waste, or the products from solidification of high-level liquid waste, or irradiated fuel elements if discarded wi thout processing.

Other Liquid Waste. Liquid waste, not within the definitions of high-level liquid waste. 
Transuraniun-Contaninated Solid waste. Wastes contaminated with certain alpha-emiteing radionuclides of long half-life and high specific radiotoxicity to greater than $10 \mathrm{nCi} / \mathrm{g}(10 \mu \mathrm{Cl} / \mathrm{kg})$, subject to the following conditions and understandings:

1. The radioncclides included are ${ }^{233} \mathrm{v}$ (with. its daughter products). plutonium, and transplutonium nuclides except ${ }^{233} \mathrm{Pu}$ and ${ }^{241} \mathrm{Pu}$. (Note that ${ }^{238}$ Pu and 241 pu waste should be handled as transuranium-contaminated waste when so indicated by ${ }^{239}$ Pu inpurities or when required by local burial criteria.)

2. The activity density alay be averaged over the contents of individual shipping containers, such ar 55-gal drums, including materials added for stielding or sorption of liguids.

Discussion

To apply the AEC system, the following wast: characteristics must be known:

- Physical state (solid, liquid).

- Thermal energy.

- Source of waste.

- Transuranic activity concentration.

It should be noted, also, that this system (1) considers physical state, (2) does not indicate the hazard potential, and (3) may be too restrictive. 


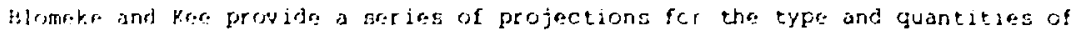
wastes laist will br: gronerated by the nuclear fuel cycle until approximately thr. giar zouts. 07

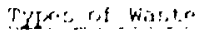

Thef idrentify and discare the following types of radioactive wastes:

High-l,revrl Wastes. Thresc are composites of the liquid waste stieams arising from the rreprocessing of spent fuels. They contain more than 99.98 of the nenvelatils. Fission produr:ts, 0.58 of the uranium and plutonium, and all the ather actinifres formed by the transmutation of the uranium and plutonium in thre ractiors.

Clarding wastes. These consist of solid fragments of zircaloy and stainless sterl clarding and other structural components of fuel assemblics that remain after the fuel cores have been dissolved.

Noble Gas Fission Products. These include krypton separated from reprocessing plant of - gas and packaged together with other collected noble gases.

Fission-Product Iodine. This is iodine whose radioactivity at the time of packaging aid shipment is due solely to ${ }^{129} \mathrm{I}$ that has a $1.2 \times 10^{7}$ year half-life and is recovered at the reprocessing plant.

Tritium Wastes. These are wastes generated at nuclear power stations and reprocessing plants.

Carbon-14. This is carbon produced in oxide-fueled reactors principally by an $(n, p)$ reaction with ${ }^{14} \mathrm{~N}$ impurity in the fuels, but also as the produci of an $(n, \alpha)$ reaction with ${ }^{17} 0$. 
Low-Level rransuranic wastes. These are solid or solidified materials that contain plutonian or other long-lived alpha emitters in known or suspertrd concentrations greater than $10 \mathrm{nCi} / \mathrm{g}$, ard yet have sufficient ly low external radiation levels after packaging that they can be handled directly.

Intermediate-Level Transuranic Waste. These solid or solidified matrridis contain long-lived alpha emitters at concentrations greater than $10 \mathrm{nci} / \mathrm{q}$, and have typical surface does rates of $10-1000 \mathrm{mrem} / \mathrm{hr}$ after packaging dup ission-prodict contanination.

Nontransuranic Waste. This is waste composed of diverse materials contaminatod with low levels of beta- and gamma-emitting isotopes, hut containing less than $10 \mathrm{nCi}$ of long-lived aipha actjujty per qrain.

Ore Tailings. These are the results of mining and milling operations for thr recovery of yellow cake, $\mathrm{U}_{3} \mathrm{O}_{8}$.

\section{Discussion}

Thr following properties of radioactive wastes must be specified when using the Blomeke and kee classification system:

- Source of the waste.

- Physical properties of the waste.

- Activity concentration for long-lived $\alpha$-emitters.

In addition, it should be noted that the system: (1) is clear-cut in its definitions of categories; (2) provides no guidance for the disposal of waste; and (3) gives little indication of relative hazard. 


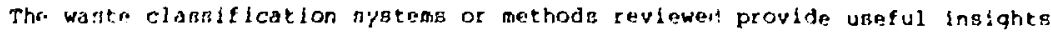
on romo of the important considerations for the further developont of a sisliabl nonten. These considerations include:

- Degrear of potential hazard.

- Mrasurf of potential health hazards such as MPC.

- Prysical gtatr (solid, liguld, or gaseous).

Of equal riphasis and inportance, but less of ten included in classification systen, are the following considerations:

- Hazard duration; (half-life).

- Disposal options, contalners, conditions, and permanence.

- Specific nuclide content.

- Specific emissions; alpha or beta-gama emiszions.

- Point of waste generation in the fuel cycle (1.e., waste strean of first cycle of reprocessing, hulls, etc.).

In many cases, the characteristics of radiaactive waste included in the definitions of waste classes are overlapping or cedundant. 
REPERENCES

C1. International Atomic Energy Agency, Standardization of Radioactive waste Categories (November, 1967).

C2. American Institute of Chemicai Engineers, Proposed Definition of Radioactive Waste Categories (1967, since withdrawn).

C3. P. Gera, "The Classification of Radioactive Wastes," in Health. Physics. vol. 27 (Pergamon Press, 1974).

C4. G. Branca and F. Gera, Proposed Classification of Radioactive Waste, C.N.E.N. Internal Report, Rome (1968).

C5. American National Standards Institute, "Categories of Radioactive Waste: ANSI-N525" (Draft).

C6. U.S. Atomic Energy Commission, "Radioactive Waste Management," Part $I$, AEC Manual, Chapter 0511, Appendix 0511, (September 19, 1973). (Now a DOE Manual Chapter.)

C7. J. O. Blomeke and C.W. Kee, "Projections of Wastes to be Generated," International Symposium on the Management of wastes from the LWR Fuel Cycle (July, 1976). 


\author{
AEEENDIX O \\ WC: BYSTHMS PROPJSED EY TAP MEMBEPS
}

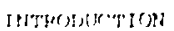

rhar colas:if icatirs systems prestented in this appendix are those proposed by the panra mitnters in the ThP's working gessions. A few of these systems were drovelryars in somr dretail. Others represent the basic structure that a rlassification system might have. with only brief analysis of the detai Is that may be nocessary in applying wuch systrms.

PROKOIED WASTE CIASSIFICATION SYS'TEM 1

\title{
Drscription
}

The primary, nsideration in the development of waste classification system 1 (Rodger, 1975) is the method of waste disposal. The basic criterion applied is that the disposal method will provide reasonable protection to man and his environment.

The disposal methods are divided into four major categories:

Release of effluents. The release of radioactive wastes whose concentrations are in compliance or can be made to comply with guidelines given in $10 \mathrm{CFR} 20^{\mathrm{Dl}}$ for discharge directly to the environment.

Interim storage. The storage for an unspecified length of time of radioactive wastes to wwalt radioactive decay; special treatment such as solidification, incineration, chemical change, heat dispersal, etc.; shipment, or any other operation that may reguire retention of the waste for some period of time. 
Active confinement. Careful selection of sices where nuclrar wasta can ton

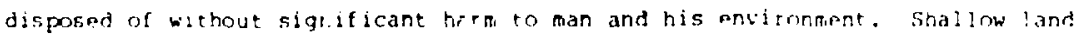
burlal wride fall into this category.

Isolation. Methois that isolate the waste from man and hice roviennment fre

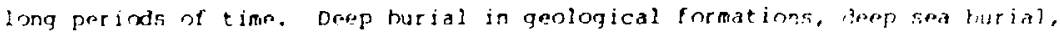
and retraterrestrial disposal methods would fall in this riatrigry,

\section{Discussion}

All radioactive isotopes could he classifierl into two groups basmd a theit potential hazard (see Pig. Dl). These would be sinilar to tho spusn arnips astatilished for radioactive shiphents as given in 496FR173. 207. 02 It wis: suggested that all radioisotopes that fall into transport : T and II t:o classirjer as Waste Group I. All other nuclides are classitsed as Wastr. Grmin Il with the pxception of ${ }^{106}$ Ru, which should qo into waste Group J. This would place in G: I all the heavy element alpha emitters (incluring TRUr) plus hazardous be. emitters such as ${ }^{90} 5$ and ${ }^{106}$ Ru.

In addition, it is proposed that concentration and total inventory limits br: established for each individual site selected for active confinement. The ¿imits for waste Group I material would be more restrictive than those for Waste Group II materlal. The limits would be further defined as one Iimit for the immediate time and one limit for $200 \mathrm{y}$ after use of the site. A period of $100 \mathrm{y}$ is suggested because it seems reasonable that control of the site can be maintained for this length. It is also the time in which fission product nuclides decay significantly and TRU nuclides assume greater relative importance. The total inventory limits would be established after careful study of the site. Such factors as rainfall, subterranian water flow, ion exchange in the soil, and so on, would be used to establish both the inmediate and the 100-y limits.

Included as Appendix $E$ in this report is Part 173.389 of Title 49 of the Code of Federal Regulations, This classifleation system is used for radioactive waste transportation purposes and has been quite satisfactory. 


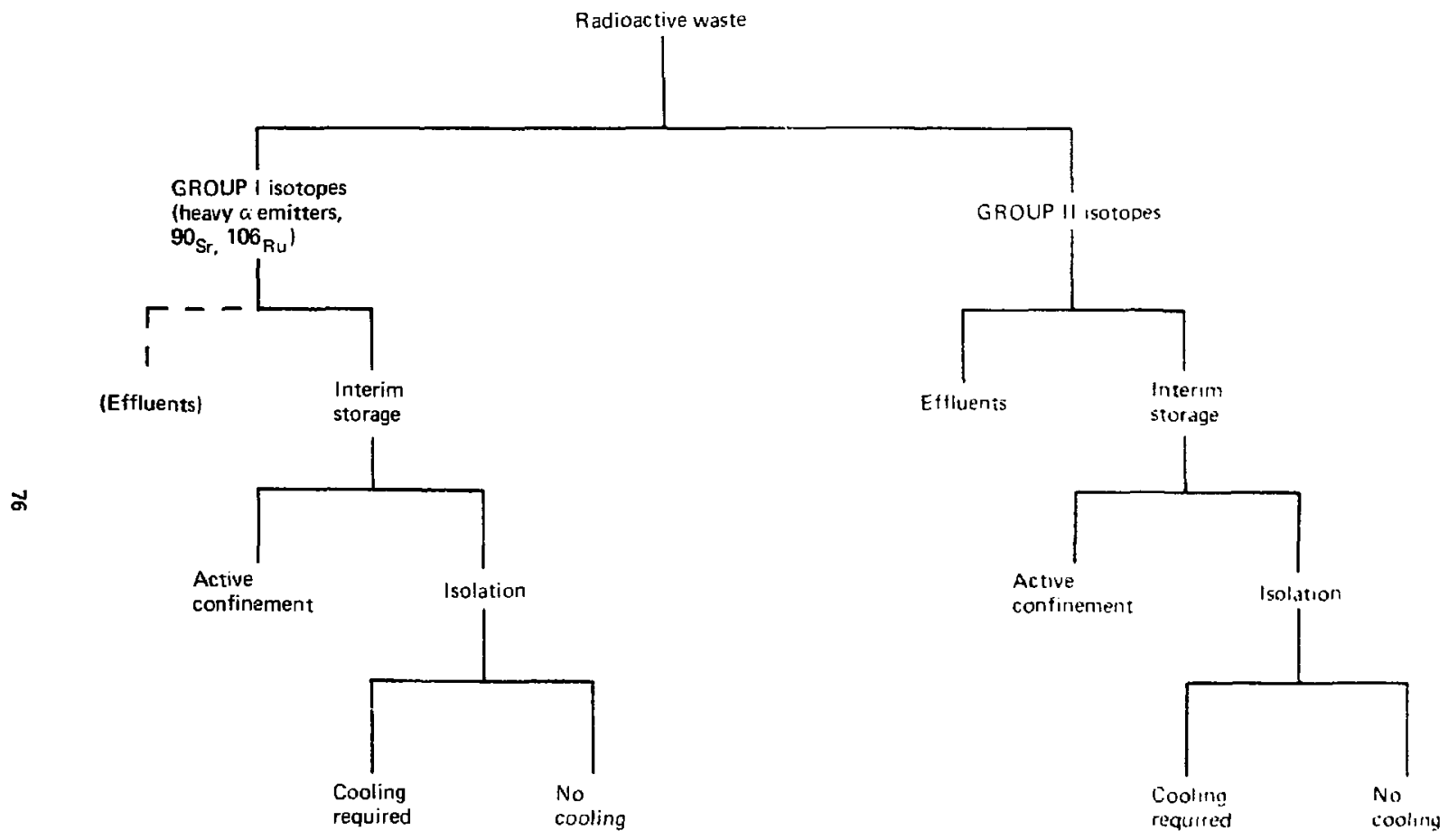

FIG. Dl. Waste classification system 1 . 
On the other hand, the same concentration limits would be expected for all sites in the country. These limits should be established after careful study of the potential hazard, in the case of an accidental entry into the huried material. Some preisinary figures to illustrate the point are as follows.

Conc ztration Iimits for waste Group I material could be:

1. For immediate burial $--1.5 \mathrm{Ci} / \mathrm{m}^{3}$.

2. For $100-y$ burial $-0.15 \mathrm{ci} / \mathrm{n}^{3}$.

Concentration limits for waste Group II material could be:

1. For immediate burial - $15.0 \mathrm{ci} / \mathrm{m}^{3}$.

2. For 100-y burial -- $1.5 \mathrm{ci} / \mathrm{m}^{3}$.

For example, assume that a plant has a 55-gal drum (volume $=0.208 \mathrm{~m}^{3}$ ) of waste containing $60{ }^{90} \mathrm{Sr}$ and $40{ }^{106} \mathrm{Ru}$, by activity. The immediate burial linit of $1.5 \mathrm{ci} / \mathrm{m}^{3}$ implies that the drum nay contain at burial:

$$
{ }^{90} \mathrm{Sr}+{ }^{106} \mathrm{Ru}=\left(1.5 \mathrm{Ci} / \mathrm{m}^{3}\right)\left(0.208 \mathrm{~m}^{3}\right)=0.312 \mathrm{Ci},
$$

with

$$
(0.6)(0.312 \mathrm{Ci})=0.19 \mathrm{ci} \text { of }{ }^{90} \mathrm{sr}
$$

and

$$
\text { (0.4) }(0.312 \mathrm{Ci})=0.12 \mathrm{Ci} \text { of }{ }^{106} \mathrm{Ru} \text {. }
$$

The 100-y limit of $0.15 \mathrm{ci} / \mathrm{m}^{3}$ implies that the drum may contain at burial:

$$
{ }^{90} \mathrm{Sr}\left(\mathrm{e}^{-\lambda} \mathrm{t}\right)+{ }^{106} \mathrm{Ru}\left(\mathrm{e}^{-\lambda} 2^{t}\right)=\left(0.15 \mathrm{Ci} / \mathrm{m}^{3}\right)\left(0.208 \mathrm{~m}^{3}\right)=0.0312 \mathrm{Ci} \text {. }
$$

where $\lambda_{1}$ and $\lambda_{2}$ are corresponding decay constants and $t$ is time. Since at burlal there is two-thirds as much ${ }^{106} \mathrm{Ru}$ as ${ }^{90} \mathrm{Sr}$, then at burial: 


$$
{ }^{30} \mathrm{Sr}=\frac{0.0312 \mathrm{cj}}{\left.\left(0^{-\lambda} \mathrm{t}^{\mathrm{t}}\right)+2 / 310^{-\lambda} 2^{t}\right)}=0.34 \mathrm{cj}
$$

and

$$
{ }^{10 F_{3}} \mathrm{Ru}=2 / 3(0.35)=0.23 \mathrm{Ci} .
$$

Sunc: the infludiate burial linits are more restrictive in this case, the amount ef 90 iar and ${ }^{105}$ Ru allowed per orum would be $0.19 \mathrm{Ci}$ and $0.12 \mathrm{Ci}$, rapipationly.

For a mixturn of plutonium isotopes, the governing criterion will be $100 \mathrm{~m}$ r., rial limits brecising of the long half-lives of the plutonium isotopes. This is: risvirusly thr case for ${ }^{239}$ pu with a $25,000-y$ half-life. For shorter I iured ${ }^{23 B} \mathrm{Pu}\left(\mathrm{T}_{1 / 2}=89 \%\right)$, the following example leads to the same conclusion.

Assuni. that a plant has the san:- 55 gal drun containing waste with a comprestion of $808{ }^{90} \mathrm{Sr}$ and $208{ }^{238} \mathrm{Pu}$, by activity. The immeriate hurial linit of $1.5 \mathrm{Ci} / \mathrm{m}^{3}$ implies an activity limit of $0.25 \mathrm{Ci}$ of ${ }^{90} \mathrm{Sr}$ and $0.062 \mathrm{Ci}$ of ${ }^{238} \mathrm{Pu}$. The $100-\mathrm{Y}$ burial limit of $0.15 \mathrm{ci} / \mathrm{m}^{3}$ implies activity lidits of $0.15 \mathrm{Ci}$ of ${ }^{90} \mathrm{Sr}$ and $0.038 \mathrm{Ci}$ of ${ }^{238} \mathrm{Pu}$. It can be seen that the 100-y limit is more restrictive in this case involving isotopes of longer half-lives, although both are less than $100 \mathrm{y}$.

For wastes in acceptable containers falling above these immediate and 100-y limits, isolation is required. Wastes destined for isolation from the enviconment should be divided into two subgroups depending on decay heat generation.

\footnotetext{
Note: In this example, the 100-y limit restricting the total activity of ${ }^{106} \mathrm{Ru}$ at burial is purely academic. Since ${ }^{106} \mathrm{Ru}$ has a half-life of $1 \mathrm{y}$. one could bury $7.5 \times 10^{26} \mathrm{Cl}$ of ${ }^{106} \mathrm{Ru}$ and at $100 \mathrm{y}$ be within the astivity limit for that drum.
} 


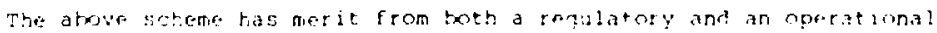
standpount. Agaln, the lijijt figures usmd wern somwhat artierary, and

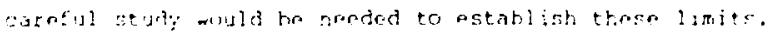

PROPOSED WASTE CIASSIFICATION SYSTEM 2

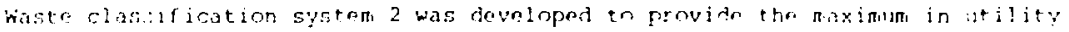
witl; complete operational couragr. D3 The systen muct ratirfy the

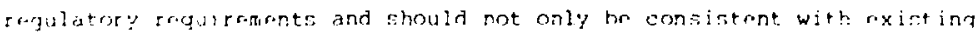

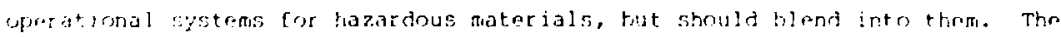
cla.sis icatir.. of a particular materjal should not changn as it mover through

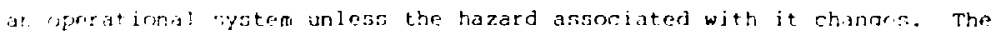

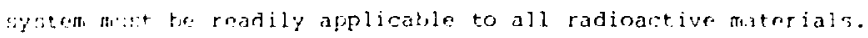

\section{Scope}

The main conalderation of the systent was to serve the regulatory nereds for radioactive wistes. Thre is a real need to move back into the nuclear furl cycle in ordar to provide a system consistent with oprration of thr nuclear power plants. Wastes are generated at each point in the fuel cycle. The rarluactive properties that define the hazard of radioactive wastes are also characteristic of many other materials in the fuel cycle, in the nuclear industry in general, and in the entire range of other activities using radioactive isotopes. Thus, the inclusion of these materials is virtually autonatic in a system designed to meet operational needs by use of the properties and characteristics of radioactive nuclides.

\section{Design Considerations}

For the classification system to meet regulatory needs, it must relate the characteristics of the wastes to the hazards to be controlled. These character istics include:

- Magnitude of the penetrating radiation.

- Hazara index.

- Life of the hazard.

- Mobility of the material. 
In addition, the opecational requirements should be recognized so that the operators may respond to the precautions implied by the classification.

The operations that will be affected include:

- Chemical processing operations.

- Handling operations.

- Emergency responses (e.g., during a fire).

- Transportation.

- Waste management--disposal or storage emplacement.

Detailed consideration of these factors leads to certain requirements or properties of the waste classification matrix. These are:

1. Simplicity-the system's classes must be easily recognized and the action implied by the classification readily defined and implemented without ambiguity.

2. Usefulness--the system must provide information needed in operations anä regulations.

3. Comprehensiveness-- the system must inciude all hazardous radioactive materia?s.

4. Flexibility--the system should permit changes in the classification of a material whose hazard has changed, and it should also be able to incorporate changes required by revisions in regulatione, policy, and hazard assessment, or by new technology.

5. Multilevel requirements--since different properties differ in operational importance for different operations, it is not necessary to have all properties identified for each. A simpler system for these operations can be provided by including different levels of classification.

6. Precise definition--each class will be designated by a rom in numeral and each subclass by one or more letters.

\section{Primary Categories}

The primary categories provide operating and control information needed in the conduct of each of the operations. These relate mainly to the handing 
requirements and are distirguished by the need for cooling, shielding, and coping with an existing biological hazard. The most intense tadioactive materials are those that require cooling. All such materials require shielding and present a large biological hazard. The next less hazardous materials are those requiring shielding but no cooling. The next less hazardous materials do not require shielding but contain materials that present a radioactive hazard if ingested or inhaled. These categories are sumnarized in Table Dl.

TABIE D1. WC system 2 categories.

\begin{tabular}{clc}
\hline Catogory & Requirements & Criteria \\
I & Requires cooling and shielding & $400 \mathrm{w} / \mathrm{m}^{2}$ \\
II & Requires shielding & $200 \mathrm{mR} / \mathrm{hr}$ at surface: \\
& & $10 \mathrm{mR} / \mathrm{hr}$ at $0.9 \mathrm{~m}$ \\
III & Requires no shielding & Would exceed MPC \\
& Requires no care & if released \\
\end{tabular}

An additional category has been suggested for materials that would be diluted below MPC in leaving the controlled area. This category, if adopted, would become IV, and "Innocuous" would become $v$.

\section{Subcategories}

Subcategories are needed to delineate the other factors and properties of concern. One of the most important of these relates to the duration of the hazard. The hazazds due to radioactive materials are complex, depending on many physical, chemical, and physiological phenomena, but they have been guantltatively defined by other authorities whose definitions we may use. 
We need consider only the changes in hazard occurring with time. Each isotope decays in a precisely defined manner so that the $r$ ate of decrease or growth of each radioisotope and its attendant hazard can be readily calculated. Fairly accurate approximations for certain groups of isotopes, such as those fram the fission process, are also available. We then define a subcategory that classifies the wastes according to the time the material stays within a category. When this time is exceeded, the waste then drops into the next lower category. This particular subcategory has a special meaning fcr waste marzgement regulations in that it is probably the principal criterion for distinguishing between wastes that may require disposal with assured permanent isolation from the biosphere and those that may safely be disposed of with less severe restrictions. The time required for the radioactive hazard to decrease to acceptable levels, if short with respect to the anticipated duration of effective management control, would permit the less restricted emplacement system. Radioactive materials that would exist as serious hazards for times that are long compared with the anticipated duration of effective managenent control would probably be placed in geologic isolation oi in some other system isolated from the biosphere. Note that the transuranics, when treated as wastes, would be included in this latter subcategory. Other long-lived isotopes, however, may also be included, even some with "infinite" half-lives (i.e., the stable isotopes), if sufficiently toxic.

The next subcategory defines the physical state or mobility of the waste material, and the Einal subcategory determines whether or not treatment is required for some regulatory consideration. These subcategories are sumnar ized in Table D2.

\section{Waste Classification}

A symbol consisting of several letters can be used to identify the various categories and subrategories. These are summarized in Table D3. 
TABLE D2. WC systein 2 subcategories.

\begin{tabular}{|c|c|c|}
\hline Symbol & Meaning & Criteria \\
\hline a & \multirow{4}{*}{$\begin{array}{l}\text { Lifetime for changing } \\
\text { category. }\end{array}$} & $<10 y$ \\
\hline b & & $10-100 y$ \\
\hline$c$ & & $100-1000 \mathrm{y}$ \\
\hline d & & $>1000 y$ \\
\hline $\mathbf{s}$ & solid & Imnobile \\
\hline \multirow[t]{3}{*}{$m$} & \multirow[t]{3}{*}{ Mobile } & Will disperse or \\
\hline & & become airborne if \\
\hline & & container is spilled \\
\hline 1 & Liquid & will flow onto a flat \\
\hline & & surface from a snall hole \\
\hline \multirow[t]{2}{*}{9} & \multirow[t]{2}{*}{ Gaseous } & Will mix with the atmosphere \\
\hline & & through a small hole \\
\hline \multirow[t]{2}{*}{$\mathrm{t}$} & \multirow[t]{2}{*}{ Treatment } & Must be converted to another \\
\hline & & form before further processing \\
\hline$n$ & No treatment & -- \\
\hline \multirow{2}{*}{$e^{e}$} & \multirow{2}{*}{$\begin{array}{l}\text { Explosive } \\
\text { Fissile }\end{array}$} & Not chemically stable \\
\hline & & Special nuclear materials \\
\hline
\end{tabular}

$a_{A n}$ alternative definition could be "lifetime until waste leaves category III (becomes innocuous)."

bay be added if desired for completeness, but waste materials cther than the transuranics should have no significant fissile content. 
TABLE D3. WC system 2 symbols and meanings.

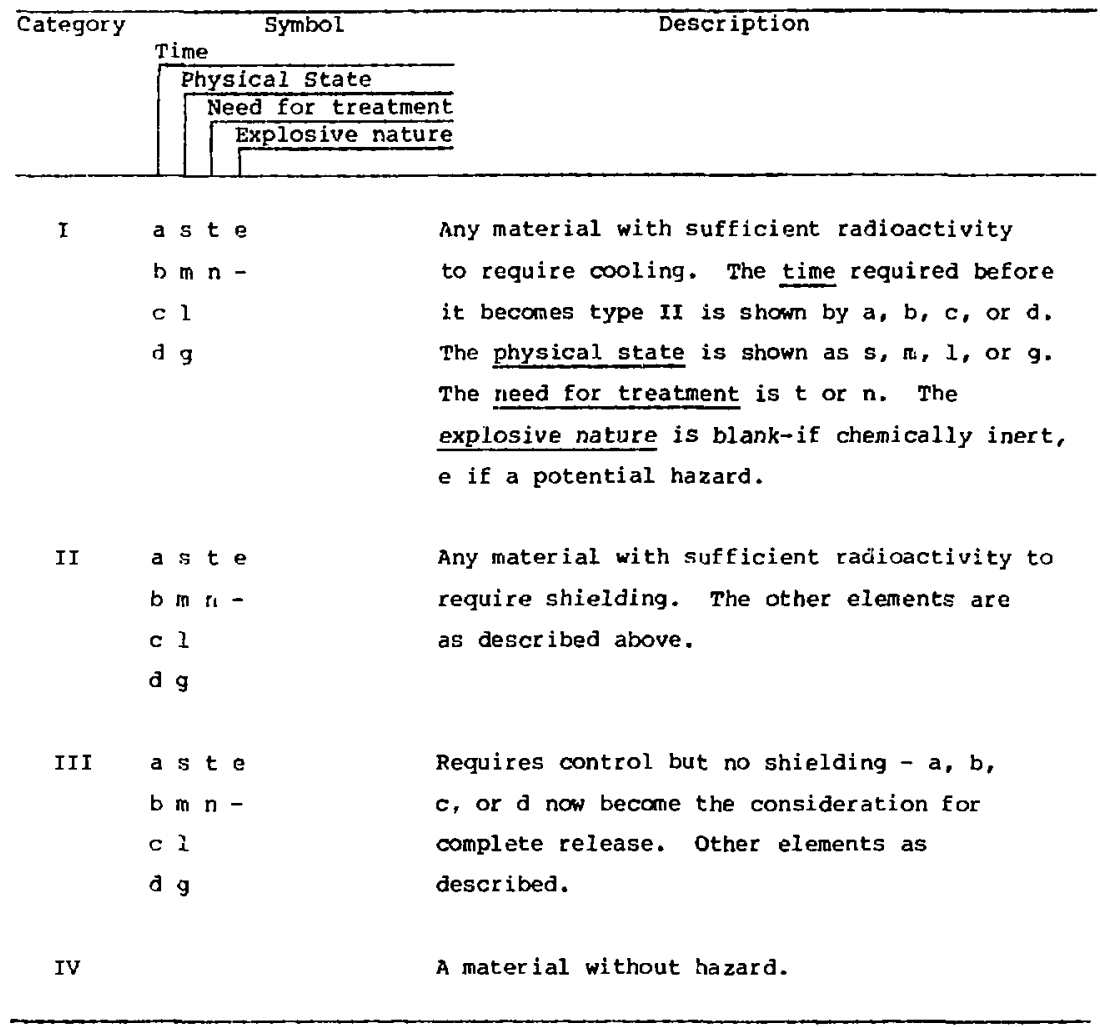

How wastes would be classified in this system can be illustrated by the following examples. Liquid waste from fuel reprocessing, which includes the unburned transuranics, as it is stored on site for eventual solidification, would be classified: 

I $(a, 1, t)+$ remains in category I unt1l 1985.
II $(c, 1, t)+$ remains in category II until 2100-3000.
III $(d, 1, t)+$ cemains in category III indefinitely.

Upon solidification, this waste becomes:

I $(a, s, n)$, etc.

Filters containing only ${ }^{131}$ I would be classified as:

II $(a, s, n)$.

A number of facets of the suggested system are arbitrary and can be adjusted to include other considerations or to improve overall consistency.

Figure D2 is a simplified diagram of waste cassification systen 2 .

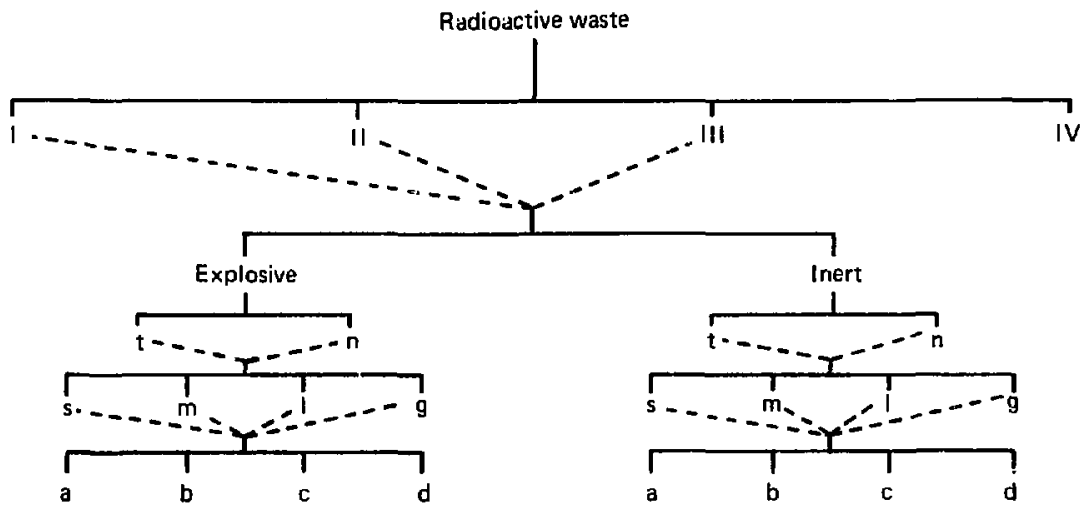

EIG. D2. Waste classification system 2 . 
PROPOSED WASTE CLASSIFICATION SYSTEM 3

Briefly outlined, the following slmple classification system in based on thermal and radiation properties of the wastes (see Fig. D3).

Vaste property

Current waste type

Thermal Radiation

$\begin{array}{lll}\text { Hot } & \text { Hot } & \text { HLW } \\ \mathrm{CoO} 1 & \text { Hot } & \text { Hulls } \\ \mathrm{CoO} 1 & \text { CoOl } & \text { LLW }\end{array}$

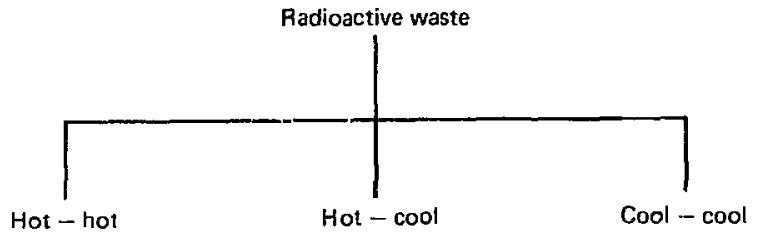

FrG. D3. Waste classification system 3. 
The following format and criteria suggest a $\mathrm{kc}$ system based on enviromental criteria (see Fig. D4).

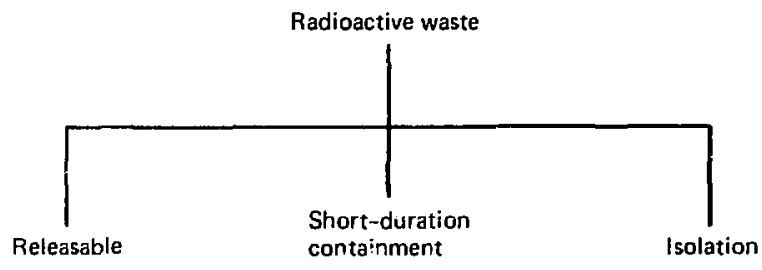

FIG. D4. Waste classiflcation system 4 .

\section{Releasable}

These are waste-satisfying conditions less than those set by "lower bound" criteria. These may be directly released as nonhazardous wastes such as normal trash, garbage, or sewage without further treatment.

\section{Short-Duration Containment}

These wastes satisfy the following conditions:

1. Criteria greater than those set by "lower bound" criteria where these criteria might be developed on the basis of: (a) comparision with natural deposits and acceptable natural-hazard limits and compliance with ALARA principles; (b) $\$ 1000$ per man-rem (10 CFR 50, Appendix I) ${ }^{\mathrm{D}}$; and (a) MPC values less than $10 \mathrm{CFR} 20^{\mathrm{Dl}}$ MPC limits.

2. Hastes with hazard durations less than those specified by "midale bound" criteria. 


\section{Isolation}

These wastes satisfy conditions greater than those set by "lower bound" criteria but with hazard durations greater than those set by "middle bound" criteria, which might be developed on the basis of:

1. Inventory commitment, as discussed in WASH-1539. D5

2. Age between 100 and 1000 Y (Rodger, 1975). D6

PROPOSED WASTE CLASSIFICATION SYSTEM 5

Early in the tenure of the TAP, a he system based primarily on two disposal modes was suggested. Wastes would be classified first as (1) those to be disposed of in shallow land burial sites, and (2) those to be disposed of in deep geologic formations.

Wastes destined for deep geologic disposal would be further categorized as high-heat or low-heat wast s. Low-heat wastes should be further classified as those requiring shielding and those not requiring shielding. 


\section{REFERENCES}

D1. Code of Federal Regulations, Standards for Protection against Radiation, Title 10, Part 20 (10 CFR 20), U.S. Nuclear Regulatory Commission (Nov. 1960).

D2. Code of Federal Regulations, Title 49, Part 173.389 (49 CFR 173.389), "Transportation--Radioactive Materials; Definitions," General Servises Ariministration (1975).

D3. M. Karol and R. Post, Comprehensive Operational Waste Classification System, University of Arizona, Tuscon, Ariz., EES Series, Report No. 4B (1977).

D4. Code of Federal Regulations, Licensing cef Production and Utilization Facilities, Title 10, Part 50 (10 CFR 50). Appendix I, "Numerical Guides for Design Objectives and Limiting Conditions for Operation To Meet the Criterion 'As Low as Reasonably Achievable' for Radioactive Material in Light-Water-Cooled Nuclear Power Reactor Effluents" (Dec. 1975).

D5. Management of Commercial High Level and Transuranium Contaninated Radioactive Wasie, Environmental statement, USAEC Report WASH-1539 (Sept. 1974).

D6. W. A. Rodger, Critical Evaluation of the Limits of Transuranic Contamination of Low Level Waste, Nuclear Safety Associates, Bethesda, Maryland (Aug. 1975). 
\$173.399 Nodionctive moterisls; definitions.

For the Jurpute of Farts 170-189 of this chapter:

(a) "Ficsile radioactive to a terlal" means the foliowing meterial: Pliton/ura-238, p:Ltonicen-239, plutonlim241, urandum-233, or uranium 235 , or any materla! conta!ning any of the fereEoing materfils. Sce $1173.3 \mathrm{Gg}(\mathrm{a})$ for exclustons. Flssite mdloactlye meterlal packisets are clesslfed a cording to the controls needed to provide nuclear critically safety durlr.g irarisportation as fclions:

(1) Fissile Class 7 , Packares which may be 1:ar.sported in unilmited nursbeis and in ang orrargemert, and whlch require no nuclear citticallty safety controls durlng transportation. Fur purpases of juclear crducality safety control, a trassport Incex is not nsslened to Flsslye Class I pachaes. However, the external radiation levels may require a transport index number.

(2) Fissile class $J$. Packnges which mas be transported together In asy arrangement but in numbers whlch do not excced an agsregate transport fndex of 50. For purposes of nuclear catirnlity safety control, Indistdunl prohages niay have a trnasport index of not less than 0.1 and not more than 10 . However, the external radjation leveis may roquire a higher iransjert index number but not to exceed 30 . Such simlpments require no nucleer critleally saicty control by the shipper durtar transportation.

(3) Fissits Cisss JIT. Shlpments of pacionges titich do not meet the requlrements of Flsslie Class I or II ard whlch are controlled to proutce nucienr crittcality salety sn transportation by speclal errongements between the shipper und the carricr.
Jiore 1: Dinclusa-235 exlots oed is cowbläton Fi:3 ratisus pricentrice of ura.

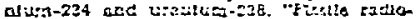
actis matertat" or applet to urandiven-235 Iefers to t?:c t=0...

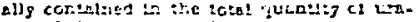
DJ

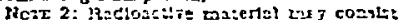

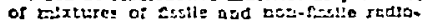

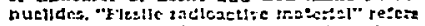

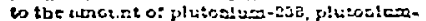

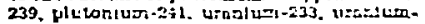
235. or any combinstion thereo: nctunly contalned in tho indxture. Tho "radlcact: ptig" of the cirtione consists of the wing ectlvitg of both the fistlo nat nonessile

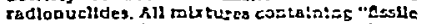
materda?" sholl bo cubjece to 1 i:3390.

(b) "Large quantt'y jadicacltre cateHels" meins a quantfty the earerertete radloactivity of whtch exceed that 5y,ec:fied as follors:

(1) Groups I or II (ste paragraph (h) of hils section) racjonuclldes: 20 curjes.

(2) Groups 13 Gr IV radionuclides: 200 curies.

(3) Group V rad!onuclites: 5.000 curles.

(4) Groupz VI or VII radionuciddes: 50.000 curles.

(5) Speclal form material: 5.000 curies.

(c) "Low spectic activlty materlal" means any of the followisn:

(1) Uranlum or thorlum ares and physleal or chemical concentratcs of tho:e otes:

(2) Uniradjated nituraj or eiepleted uranium or uniracilated natura! thorlum:

(3) Tritlun oxlde in aquecus zoluAuns proutded the concentration docs not.exceed 5 mllilcurles per milliliter:

(4) Material in whuch the ucistis is essentially unlformy distributed and in which the estimated averege concentra. tion per gram of contents does not exceeus:

(i) 0.0001 milileurfes of Group I (see $173.389(\mathrm{~h})$ ) sadloisucllodes: or

(ii) 0.005 mallicuries of Oroup II radlonuclldes: or

(1ii) 0.3 malltcusteg of Groupg : $\Pi$ or iV radionucllces.

Norz: This tucluces, but ls pot limlted to, mater lais of low radroctivity concerisation cuch bs restaues or colutlons from cluculcal processfog: nestes cuch as bulldlog rubble. metal, wod. and rabilc serap. Elassware. paper nnd carcboard: colld or llaisld pleat wrste, siudbes, agd attea.

(5) Objects of nonradioactive $\mathrm{ms}$ tcral extemally contuminated rith radinective msterins. provided inat the 
radiogctuve matcrial is not read!:y d!sperslble and the sirface contiajoition then everaced over an aten of 1 squarc neter, coss not cxeced 0.0001 mlilicule (220,000 dirinterititons per r 1 -:utc) per squarc centineter ol Group 1 ecloruclices of 0.001 millicuac $12,200,000$ dtsintegratlons per minutel per square centlmever of other radlonuclles.

(d) "Normsl form radloactive araterlals" means those whlch arc not 5 ne clal form radioactive maicrials. Jicmol form ycloactl:e mate tals are crouped Into transport atoups lsee paragragh (h) of th:s $\leq 5 \mathrm{cll}$ (on).

(e) "Radlosctive materlal" meens any materlal or combinatlon of materlais, which spontineouslg em!ts tonIzlng radiatlon. Miatevals in Fhich the estimated specille sclivity is not Ereater than 0.002 microcutlcs ner Exan of materiel, and in which the radtojcilv!ty is essentlally colformly distr'buted, ere not consldered to be radlonctive motertals.

(1) "Removable sadioactive cortamInitlon" menss radlonctive contarianilon which can be readijg removed in measurable quantities by nipling the contaminated surface tilth an absorbent materlal. The measurabia guantities shall be considered as be!ng not slenificnnt if they do not exceed the limits specifed in 173.397.

(c) 'Sneclal form radioective materials" means those which, if released from \& package. might prescnt some direct radlation hazara but would piesentlitle haz.ird due to rad'otoxiclty and Iittle possibllty of contumination. This Ina tye the resislt of fuherent propert!es of the materia) (such as metals or a!loys). or ecquirad characteristics, as throueh encapsulation. The critcria for determlning whether a ruatertal meets the dethdion of specin! form nre prescrlbed in $173.35 a(n)$.

(h) "Transport group" means any one of seven groups into which normal form radionuclifies are classliled according to thelr rndiotoxlctiy aud thetr reintlve potentlal hazard in transportation, and as IIsted In \$173.390.

(1) "Transport Index" means the number placed on a pickinge todestgnate the degrec of cantrol to b: exerclscd by the cntrler during tiansportatlon. The transparl index to be assigned to a pachose of radfonctlye materials sha]l be determined by ejther subparasraph (1) or (2) of this paragrnph, whichever is larger. The number cxpressing the transport
Index sho!! be rounded up to the nint blfhest ienth: e.5. 1,01 tecerass 1.1 .

(1) Tác rishest radetion dose ate. in in!litica per hour fi: thice feet ixis any accessible cxuenal in:isce ot the paciaze: or

(2) Fo: Fiselle C lass II practanes cris. the trafsjort incex number calcuicind by d!vluing tre numbet "50" by the number of stmllar pactiares whtei was be trar:spotied together isee $172.33 \mathrm{~L}$. as deternined by the pruicdures pacscribed in tre rerulations of the is Atomic Enerky Connission. Ty!tc :0. Code of Fecera] Pegulations. Part 71.

(1) "Type A packathas" meanc jachogfng widch 15 designed in eccordance with the enere! pact:aging requlr crits

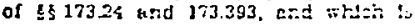
adequate to prevent the loss or dispe:sa! of the radloactive contchts a tad to re:s!a the eDciency of th radiation stelelcina propertfes if the paciace to subject to the tests prescribed in $\$ 173.398(b)$.

(k) "Type B packaglne" aneons pac:aping which meets the standards for Type A packarlas, and, in add!ion. meets the stancarts for hypo:tctlcoi eccldent conditions of transportation as preserlied in \$173.39s(c).

(I) "Type A quantity" and "Type $\mathbf{B}$ quantity" sadtoactlve materisis meass a quant!ty the asurcgate radlonctlvt!s of which coes not exceed that specticd es follon:s:

\begin{tabular}{|c|c|c|}
\hline $\begin{array}{l}\text { Tra:spott group } \\
\text { (sco } 1 \text { ITs.39u(s)) }\end{array}$ & $\begin{array}{l}\text { Tugat A } \\
\text { quactidy } \\
\text { (un cutios) }\end{array}$ & 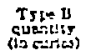 \\
\hline di & 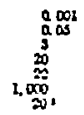 & $\begin{array}{r}20 \\
200 \\
200 \\
0.000 \\
0.00\end{array}$ \\
\hline
\end{tabular}

1 Except that ror Calforndum-252 the Tre $A$ quantity itmit for speclal foren is $z$ ctiles.

(m) Containuncrt sysfcm. Coatninment system of a radloactle matcrlals packege means those components of the packaging includ'ne spectal form cricepsulation where used, who's knve beril specllod by the package ciestgner es $\mathrm{h}$ tercied to retain the racioastive conecres during tt ussport, Rhethes or not inc? :idual vessels in the packareng rutzin tha!r Integrlts of containment.

(n) Marimum normal operating jrose sure. Mravnum normal opcrutung picssure mrans the mavinuen j:essure alvic atmosplueric pressurc ut menn sea level 


\subsection{0}

that fould deveiop in the contalnment system in a pertod of 1 year, under the condlusons of ternocature and solar radiation corresponding lo environmentel conditions of transport in the absence of ventinz. external cooling by an enclilary system, oz cperatlone! controls duriae trarsport.

\section{Titlo 49-Transportotion}

IAmdt, 173-3, 39 F, 14722, Ott, 4. 1982; 39 Fr. 19E23, Dec. 27. 1eE8, as ameneed b7 AmEt. $273-04,37$ F R. 1458s, July 21. 1072:

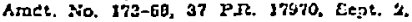
1972]

6 273.390 Transport Groups of radio nuclides.

(A) Lst of radlonuclldes:

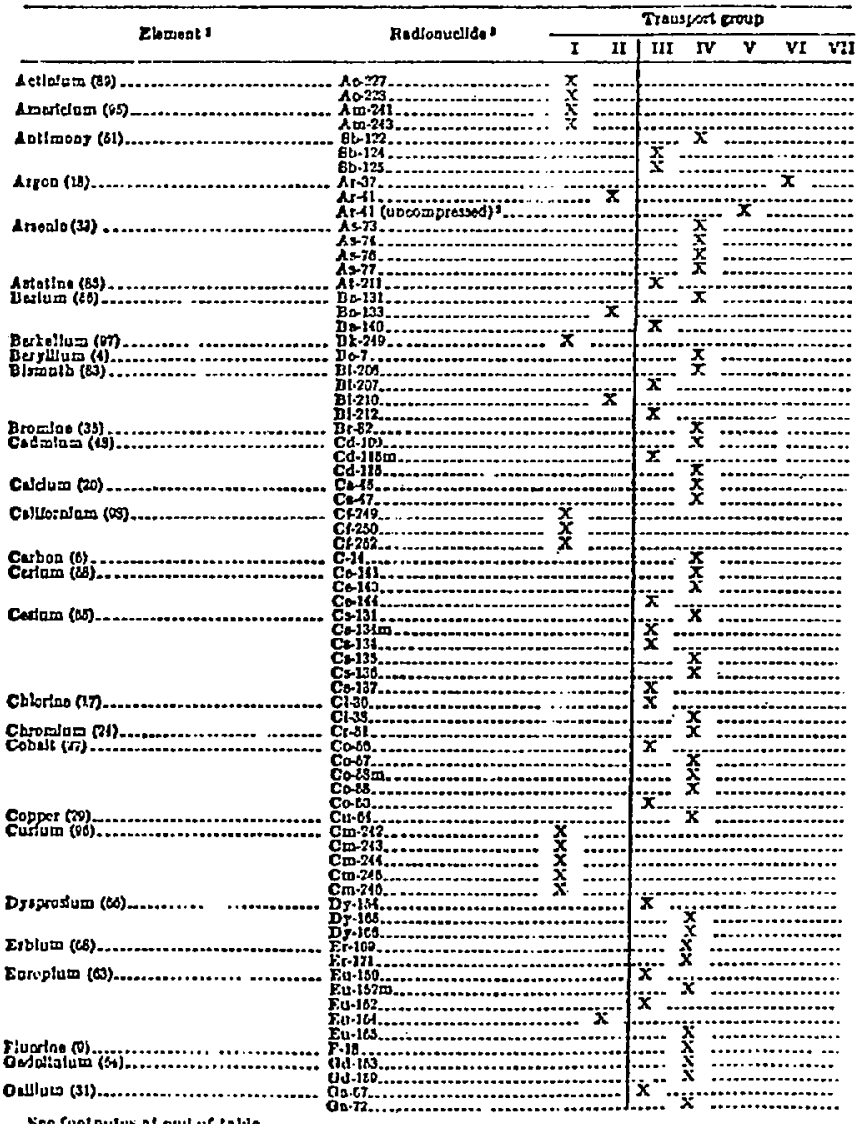




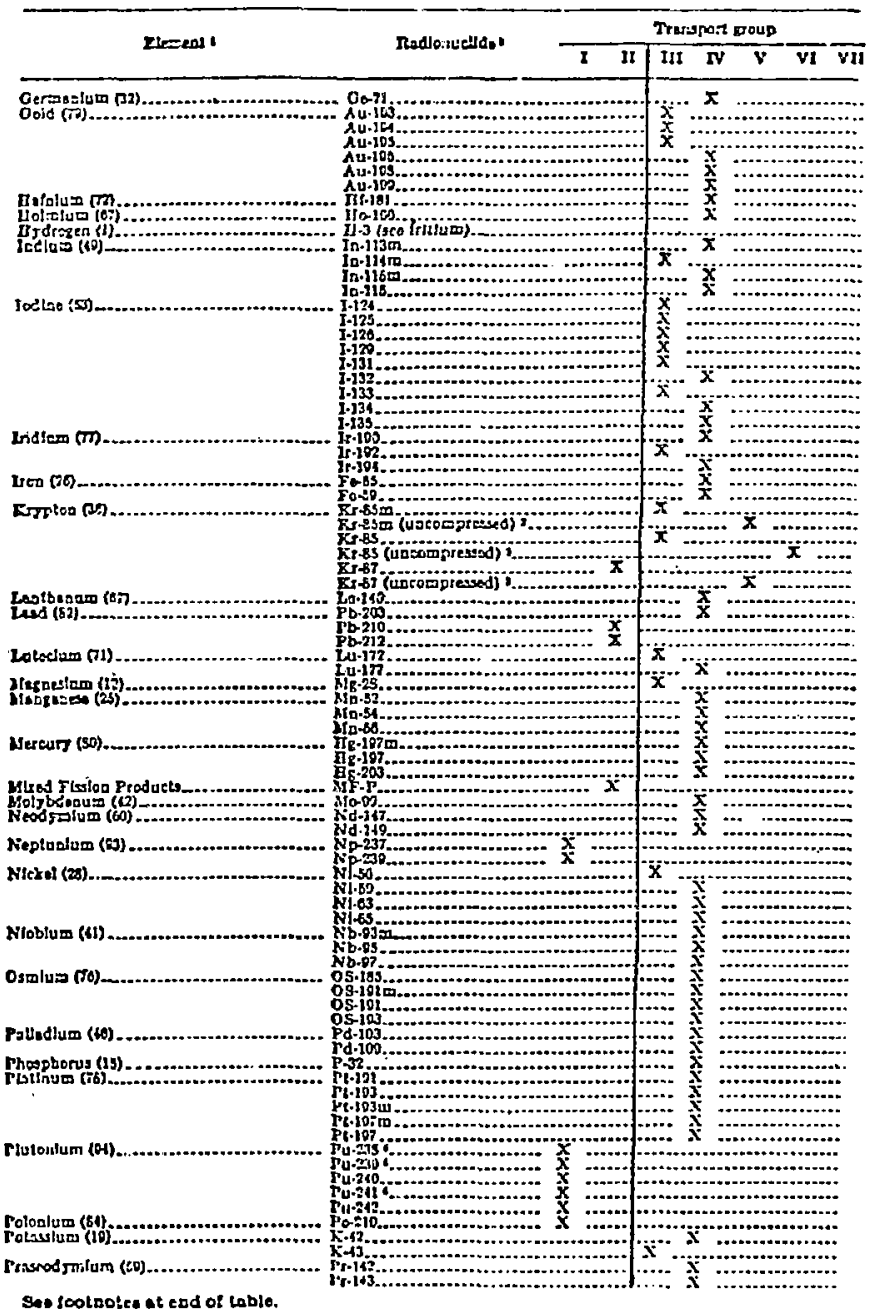




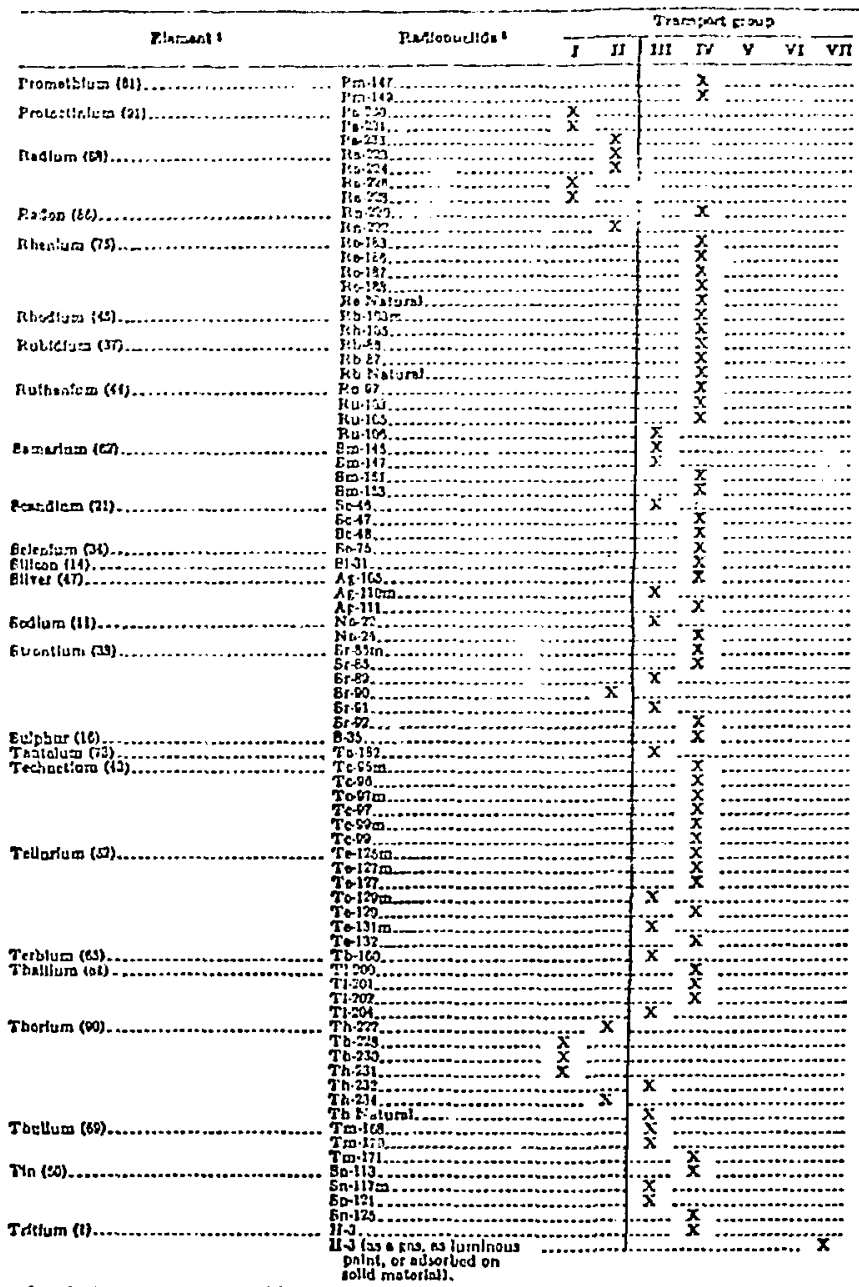

Bes footnoten at end of tnble. 


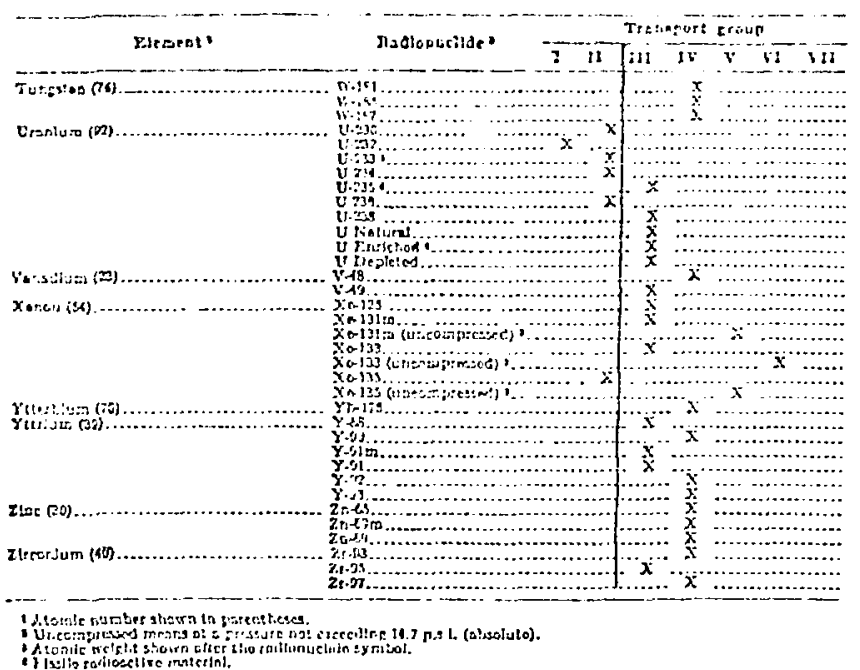

(b) Ang radlenucilde not llsted in the above tatie shall be sesigned to one of the eroups in accordance witth the tollosing table:

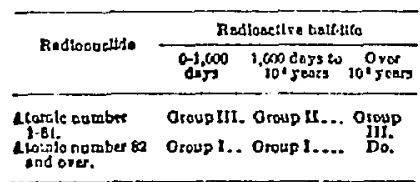

Norn 1: No unlisted ractanuclides abal be solgned to C:oujs IV, V, VI, cr VD.

(c) For mixtures of radjonucldes the tollowing shald appiy:

(1) If the Idently and respective sctlyty of each radlonucllde are known, the permissible aclivity of cach radjoacelide shall be such that the sus, for nll eroups present, of the ratlo between the lotal actlulty for cach group to the permIsslule deblifly for each group wit not be fircater thair unity.

(i2) If the sroups of the rndionuclides ere knewn but the ninount in each group cannot be reasonably detcrmined, the mixture shall be nsslencd to the most restrlalive group present.

(3) If the Ident:ty of eil or sone of the redionuellues canfot be reasonably dotemalned. eech of those undientifed radionuctides shall be cons!dered as telonglne to the most restelcive Eroup whlch canngt be posit:ve!y excluted.

(4) intures corsisting of a sing?e radlorctive decay chatn titere the racionuclides are in the neturally occurstis proportlons shali be cons!dered es conststing of a single radlonuclide. The Exoup and acturity shall be that of the first member presetit in the chain. except if a redlonucllde " $x$ " has a hale-119e longer than that of that first member snt an activty freater than trat of any otter fuember including the fist at any tiree durine transporiatlon; in biat case, the transport group of the nuellde " $x$ " and the actirlty of the mixture shail be the maximuin ncilvity of that nucllde " $x$ " durtn: transportation. [Amat. 173-3, 33 PR. 14923, Oct 4, 1008] 


\section{APPENDIX $F$ \\ CHARACTERISTICS OF EXISTING LOW LEVEL WASTE (LLW) DISPOSAL SITES}

The curcent practice in the United States is to dispose of solid LLW mainly by shallow land burlal. Hence, the reference containment facility (RCF) used in this study to analyze the degree of conflnement given LLW after disposal is based on that practice. The parameters chosen to describe the RCF came from two sources. One was the measured values of those parameters at existing facilities; the other was conservative estimates of the values to be allowed at any future hurial sites.

To gain a perspective on current LLW handling and provide a background for jutging the reasonability of the RCF, we reviewed existing low-level waste burial facilities. Fl-FT six commercial LLW burial facilities and five major active sites for burial of defense- and research-telated -adioactive wastes at DOE facilities now exist in the United States. Sources of the wastes may differ from site to site, but operational characteristics of the disposal facilities and waste compositions generally are similar.

LLW received at the disposal facilities are placed directly in pits or trenches excavated in the native soil or till at the sits. Overburden removed during excavation is used to cover the wastes. Pits and trenches are sloped, and the cover is applied to control ground water and surface runoff from precipitation. Characteristics of the existing sites are sumnarized in tables Fl through F5.

Table Fl gives the capacity of the commercial sites, the sizes of trenches or pits, the cover, fill procedures, covering frequency, and provisions for water. Table F2 gives waste inventories.

\footnotetext{
"Three sites were not receiving waste at the time of publication.
} 
Table F3 shows climatological information for each site, iucluding data on climate, precipitation, geomorphology, permeability, and bedrock. Table F4 presents hydrogelogic site information including depth to aquifer zones, nearest surface water and water flow paths, radionuclide migration, downstream river flow rate, and seismic hacard zones. Table F5 lists demographic information, including downstream populations and distances. 
TABLE Fl. Capacities, covers, and water collection provisions at existing LEW

\section{sites.}

\begin{tabular}{|c|c|c|c|c|c|c|c|}
\hline \multirow[b]{2}{*}{ site } & \multirow{2}{*}{ 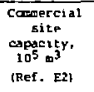 } & \multirow{2}{*}{$\begin{array}{l}\text { Eurial trineh } \\
\text { size (length } \\
\times \text { wath } \times \text { depth), } \\
\text { (Ref, E6 }\end{array}$} & \multicolumn{2}{|c|}{ Cover } & \multirow{2}{*}{$\begin{array}{l}\text { Fis: } \\
\text { procedure }\end{array}$} & \multirow{2}{*}{$\begin{array}{l}\text { covesths } \\
\text { freyzency }\end{array}$} & \multirow{2}{*}{$\begin{array}{l}\text { Protisions tint } \\
\text { vatet woliectian } \\
\text { and onntsinarst } \\
\text { (Ref. Es) }\end{array}$} \\
\hline & & & The & Depth & & & \\
\hline $\begin{array}{l}\text { Hanford, } \\
\text { Mashingtona }\end{array}$ & ---- & $\begin{array}{l}\text { Yariabie } \\
\text { t.5-5 } \times 4-8\end{array}$ & $\begin{array}{l}\text { mosnted } \\
\text { ea:the } x l 1\end{array}$ & $\begin{array}{l}\text { min. } 2.5 \mathrm{~s}, \\
\text { or io reduse } \\
\text { to it aphe } \\
\text { at surtace }\end{array}$ & $\begin{array}{l}\text { Fllied fiom } \\
\text { end }\end{array}$ & odisy & sone \\
\hline $\begin{array}{l}\text { Riehl and, } \\
\text { Mashington }\end{array}$ & 9 & $90 \times 8 \times 6$ & Eatthe 111 & $\begin{array}{l}\text { Min. } 2 \text { a } \\
\text { total; mounded } \\
\text { to I n abeve } \\
\text { grade }\end{array}$ & $\begin{array}{l}\text { Tremeh itiled } \\
\text { to } 0.6 \text {. } \\
\text { of sirface }\end{array}$ & $\begin{array}{l}\text { As trench } \\
\text { is filled }\end{array}$ & sane \\
\hline $\begin{array}{l}\text { Eeatty, } \\
\text { Nenvads }\end{array}$ & 7 & $260 \times 12-15 \times 8$ & Earthe ill & $\begin{array}{l}\text { Nin. } 2 \text { a } \\
\text { total: mounded } \\
\text { to } 0.6 \text { a } \\
\text { sbote grade }\end{array}$ & $\begin{array}{l}\text { Trench filledt } \\
\text { to } 1 \text { al of } \\
\text { surface }\end{array}$ & $\begin{array}{l}\text { As trenct } \\
\text { is falind }\end{array}$ & None \\
\hline $\begin{array}{l}\text { Inel, } \\
\text { Idatoos }\end{array}$ & $\cdots$ & $275 \cdot 2-3 \cdot+$ & $\begin{array}{l}\text { Reseeded } \\
\text { earchtill }\end{array}$ & $\begin{array}{l}\text { Mir. } 1 \text { La } \\
\text { to sirf ace }\end{array}$ & $\begin{array}{l}\text { Pits and tremehes } \\
\text { falled to } \\
\text { l* of surface }\end{array}$ & $\begin{array}{l}\text { As treech } \\
\text { ntpat is } \\
\text { fllied }\end{array}$ & Nane \\
\hline $\begin{array}{l}\text { Lus Alsoos; } \\
\text { Mes Mexicodi }\end{array}$ & --- & $120-180 \times 9-30,9$ & $\begin{array}{l}\text { Excsuated } \\
\text { tuff } \\
\text { cacpacted }\end{array}$ & $\begin{array}{l}\text { Min. } 1.5 \mathrm{mi} \\
\text { sounding } \\
0.5-1.2 \\
\text { stowen grade }\end{array}$ & $\begin{array}{l}\text { Layered fill ing } \\
\text { to } 1 \text { in of } \\
\text { surf ace }\end{array}$ & $\begin{array}{l}\text { Conbugtioles } \\
\text { on day ot } \\
\text { deiliver:. } \\
\text { other as } \\
\text { reyuired }\end{array}$ & Mone \\
\hline $\begin{array}{l}\text { Shetfleld, } \\
\text { Inlinsts }\end{array}$ & 2 & $150=15-13 \times 6-6$ & $\begin{array}{l}\text { Comparted } \\
\text { clay } \\
\text { resceded }\end{array}$ & $\begin{array}{l}\text { Min. } 1 \text { o } \\
\text { final cover }\end{array}$ & $\begin{array}{l}\text { Irench filled } \\
\text { to } 0.6 \mathrm{a} \\
\text { of surfuce }\end{array}$ & Daily & $\begin{array}{l}\text { Ttenches } \\
\text { slsped; } \\
\text { simp sind } \\
\text { standpipe }\end{array}$ \\
\hline $\begin{array}{l}\text { Morehesd, } \\
\text { Kentueky b }\end{array}$ & 31 & $60-150 \times 24=6-9$ & $\begin{array}{l}1 \text { mo } \\
\text { compacted } \\
\text { cl ay: } \\
\text { gounded; } \\
\text { resected }\end{array}$ & $\begin{array}{l}1 \text { m cover: } \\
\text { wounded } 0.6 \text { = } \\
\text { abour } 4 \text { idde }\end{array}$ & $\begin{array}{l}\text { Erench filied } \\
\text { to } 0,6 \text {. } \\
\text { of surface }\end{array}$ & Da:ty & $\begin{array}{l}\text { Trenches } \\
\text { sloped, } \\
\text { st andpipe; } \\
\text { ay triditimt } \\
\text { sxound it inch }\end{array}$ \\
\hline $\begin{array}{l}\text { Oak Ridqe, } \\
\text { Tennesseed }\end{array}$ & --- & $25 \cdot 3 \times 3-5$ & $\begin{array}{l}\text { Rcaeeded } \\
\text { eartht } 111\end{array}$ & $\begin{array}{l}\text { Hz... } 1 \mathrm{1} \\
\text { to sur face }\end{array}$ & $\begin{array}{l}\text { Treneh tithed } \\
\text { to i d of } \\
\text { surtace }\end{array}$ & $\begin{array}{l}\text { As : trench } \\
\text { is tilled }\end{array}$ & $\begin{array}{l}\text { Ttenches } \\
\text { sloped; } \\
\text { woritoling } \\
\text { welld }\end{array}$ \\
\hline $\begin{array}{l}\text { Sovannah River, } \\
\text { South Carol inas }\end{array}$ & $\cdots$ & $\begin{array}{l}\text { yariable. } \\
6 \text { - }\end{array}$ & $\begin{array}{l}\text { Hounted } \\
\text { eat atstili }\end{array}$ & $\begin{array}{l}\text { Min. } 1.2 \text { n. } \\
\text { of to reduce } \\
\text { to <6 ardhe } \\
\text { at gurface }\end{array}$ & $\begin{array}{l}\text { Random } \\
\text { pl ternent } \\
\text { in treneties }\end{array}$ & $\begin{array}{l}\text { After } \\
\text { disposs! }\end{array}$ & $\begin{array}{l}\text { Mont tor ing } \\
\text { wells }\end{array}$ \\
\hline $\begin{array}{l}\text { Bastnwe 11, } \\
\text { South Carol ina }\end{array}$ & 25 & $140 \times 15 \times 5-7$ & $\begin{array}{l}0.6 n \text { el sy } \\
\text { addit ional } \\
\text { Eounded } \\
\text { cover }\end{array}$ & $\begin{array}{l}3 \text { is at } \\
\text { center } 1 \text { ine } \\
\text { t.5 a at } \\
\text { titengh edge }\end{array}$ & $\begin{array}{l}\text { treneh filled } \\
\text { to ide of } \\
\text { surfase }\end{array}$ & Dasiy & $\begin{array}{l}\text { Trenches } \\
\text { sloped } t^{\circ}, \\
\text { sand at } \\
\text { treneh bot to }\end{array}$ \\
\hline $\begin{array}{l}\text { Nest valley. } \\
\text { Hew Yorkb }\end{array}$ & 2 & $190-210 \times 10 \times 6$ & $\begin{array}{l}\text { Earentill } \\
\text { cospocted } \\
\text { Eposolil } \\
\text { odArd }\end{array}$ & $\begin{array}{l}\text { Min. } 3 \mathrm{m:} \\
\text { mounifed } \\
\text { h.s } \\
\text { sbone de sde }\end{array}$ & $\begin{array}{l}\text { Trench filled } \\
\text { to gr ade } \\
\text { level }\end{array}$ & Danly & $\begin{array}{l}\text { Trenchoz } \\
\text { sloped fo, } \\
\text { aup vith } \\
\text { ritur pipe }\end{array}$ \\
\hline $\begin{array}{l}\text { val vet used } \\
\text { in RCF }\end{array}$ & 5 & $200=10 \cdot 3$ & $\begin{array}{l}\text { Mounded } \\
\text { esithtilt }\end{array}$ & mounded & $\begin{array}{l}\text { ruiled to } \\
\text { 1naut } \\
\text { surester }\end{array}$ & Dasiy & $\begin{array}{l}\text { Trenches } \\
\text { slopes: } \\
\text { simp and } \\
\text { st anipipe }\end{array}$ \\
\hline
\end{tabular}


TABLE F2. Waste inventories at existing ILW sites.

\begin{tabular}{|c|c|c|c|c|c|c|}
\hline site & $\begin{array}{l}\text { Byproduet anterial } \\
\text { Cí nondecayed }\end{array}$ & $\begin{array}{l}\text { Special nucleaz } \\
\text { material, } 9\end{array}$ & $\begin{array}{c}\text { source } \\
\text { material, kg }\end{array}$ & Transuranics, $g$ & $\begin{array}{l}\text { volue buried, } \\
10^{4}=^{3}\end{array}$ & $\begin{array}{c}\text { conulotive } \\
\text { through } \\
\text { dete }\end{array}$ \\
\hline $\begin{array}{l}\text { Fantord, } \\
\text { washington" }\end{array}$ & $6.1 \times 10^{5}$ & --- & $6.0 \times 10^{5}$ & $3.65 \times 10^{5}$ & 20.0 & $7 / 73$ \\
\hline $\begin{array}{l}\text { Richland, } \\
\text { washington }\end{array}$ & $5.4 \times 10^{5}$ & $5.8 \times 10^{5}$ & $1.3 \times 10^{4}$ & $2.3 \times 10^{4}$ & 1.4 & $1 / 77$ \\
\hline $\begin{array}{l}\text { beatty. } \\
\text { Nevads }\end{array}$ & $1.3 \times 10^{5}$ & $1.0 \times 10^{5}$ & $5.5 \times 10^{4}$ & $1.4 \times 10^{4}$ & 5.6 & $1 / 27$ \\
\hline $\begin{array}{l}\text { Inel, } \\
\text { Idaho" }\end{array}$ & $3.6 \times 10^{6}$ & $+\cdots$ & $2-88 \times 10^{5}$ & $3.61 \times 10^{5}$ & 14.0 & $7 / 75$ \\
\hline $\begin{array}{l}\text { Loe Al }=00 \text {; } \\
\text { Weu Mextcos }\end{array}$ & $1.6 \times 10^{5}$ & 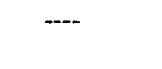 & $2.51 \times 10^{5}$ & $1.3 \times 10^{3}$ & 23.0 & $7 / 75$ \\
\hline $\begin{array}{l}\text { Sheffietd, } \\
\text { I11'nois }\end{array}$ & $4.6 \times 10^{4}$ & $4.6 \times 10^{4}$ & $1.9 \times 10^{5}$ & $1.3 \times 10^{4}$ & 6.8 & $1 / 77$ \\
\hline $\begin{array}{l}\text { Worehead, } \\
\text { Kentucky }\end{array}$ & $2.3 \times 10^{6}$ & $4.0 \times 10^{5}$ & $2.3 \times 10^{5}$ & $6.9 \times 10^{4}$ & 14.0 & $1 / 77$ \\
\hline $\begin{array}{l}\text { Oak Rtdge, } \\
\text { Tennessea }\end{array}$ & $<6 \times 10^{4}$ & --- & 100 & $1.3 \times 10^{3}$ & 18.0 & $7 / 75$ \\
\hline $\begin{array}{l}\text { Savannah Flver, } \\
\text { south Carolina" }\end{array}$ & $4.4 \times 10^{8}$ & --- & $7.9 \times 10^{4}$ & $7 \times 10^{3}$ & 20.0 & $7 / 75$ \\
\hline $\begin{array}{l}\text { Eornmeli, } \\
\text { south Carolina }\end{array}$ & $3.1 \times 10^{5}$ & $3.4 \times 10^{5}$ & $1.5 \times 10^{5}$ & $\cdots$ & 10.0 & $1 / 77$ \\
\hline $\begin{array}{l}\text { West valley, } \\
\text { New York }\end{array}$ & $5.5 \times 10^{5}$ & $5.5 \times 10^{4}$ & $2.8 \times 10^{5}$ & $3.6 \times 10^{3}$ & 7.0 & $1 / 77$ \\
\hline valueg used & & & & (DOE sites & & \\
\hline in RCF & $-\cdots$ & --- & ---- & only) & --- & $\because \cdots$ \\
\hline
\end{tabular}

Dor site 
TABLE F3. Climatological parameters at existing LLW sites.

\begin{tabular}{|c|c|c|c|c|c|c|c|c|c|}
\hline \multirow[b]{2}{*}{ Blen } & \multirow[b]{2}{*}{$\underset{c|c| c|c|}{\text { chente }}$} & \multicolumn{2}{|c|}{ Proclpitartion } & \multirow[b]{2}{*}{ 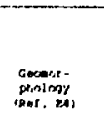 } & \multirow[b]{2}{*}{ 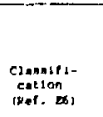 } & \multirow[b]{2}{*}{$\begin{array}{l}\text { Total } \\
\text { thicknen, } \\
\text { thap. Es }\end{array}$} & \multirow{2}{*}{ 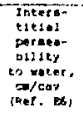 } & \multicolumn{2}{|c|}{ Bedrok } \\
\hline & & That. esi & tant. Ent & & & & & $\begin{array}{l}\text { clasidet- } \\
\text { cotson } \\
\text { fhef. Esi }\end{array}$ & serueture \\
\hline $\begin{array}{l}\text { Hantegt, } \\
\text { Washingt Ufint" }\end{array}$ & 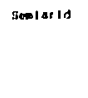 & 200 & $-8<0$ & $\begin{array}{l}\text { calintila } \\
\text { platedu } \\
\text { teat- } \\
\text { saneft }\end{array}$ & $\begin{array}{l}\text { clay, sand, } \\
\text { afd ge avel }\end{array}$ & .150 & Yar table & Eacale & $\begin{array}{l}\text { MoghLve/tlat - } \\
\text { Lying }\end{array}$ \\
\hline 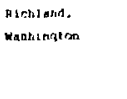 & Sorstar & 200 & -810 & 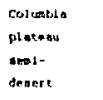 & $\begin{array}{l}\text { clay, iend, } \\
\text { and eqreyel }\end{array}$ & $=150$ & Vartable & Roralt & $\begin{array}{l}\text { Maselve/flat - } \\
\text { lying }\end{array}$ \\
\hline $\begin{array}{l}\text { Mrat:y, } \\
\text { irvadis }\end{array}$ & AIIT & 100 & 1579 & $\begin{array}{l}\text { Encin ond } \\
\text { I ange: } \\
\text { denet to }\end{array}$ & $\begin{array}{l}\text { Alluvial } \\
\text { nand ant } \\
\text { geavel }\end{array}$ & .200 & $0.02-0.1$ & $\begin{array}{l}\text { Met asorptic } \\
\text { and } \\
\text { aeriseritary }\end{array}$ & Polded \\
\hline $\begin{array}{l}\text { MHA1, } \\
\text { 1'AABn" }\end{array}$ & Semparto & 200 & -600 & $\begin{array}{l}\text { valeanle } \\
\text { amin } \\
\text { deoret }\end{array}$ & $\begin{array}{l}\text { Alluvisl } \\
\text { and and } \\
\text { gtave: }\end{array}$ & 6 & Hedetate & Garall & $\begin{array}{l}\text { hassive/fast- } \\
\text { lying }\end{array}$ \\
\hline $\begin{array}{l}\text { I.m Mlamon, } \\
\text { Him Max!eson }\end{array}$ & somlarin & 100 & - - 70 & $\begin{array}{l}\text { Hounteinous } \\
\text { Aesidesenrt }\end{array}$ & $\begin{array}{l}\text { Wantherent } \\
\text { tuff }\end{array}$ & 2 & Muderate & $\begin{array}{l}\text { Volcanic } \\
\text { tutt }\end{array}$ & $\begin{array}{l}\text { Moteblue/flat. } \\
\text { lying }\end{array}$ \\
\hline $\begin{array}{l}\text { Sherfamin, } \\
\text { 1:tinotis }\end{array}$ & Bumin' & 900 & 90 & Glacial & $\begin{array}{l}\text { Glactal } \\
\text { detits } \\
\text { Band, olle, } \\
\text { and gravel }\end{array}$ & $20-36$ & D. 201-a & $\begin{array}{l}\text { shale, } \\
\text { sandstone. } \\
\text { and coal }\end{array}$ & $\begin{array}{l}\text { Plot- } \\
\text { lyang }\end{array}$ \\
\hline $\begin{array}{l}\text { Mri elimad, } \\
\text { Reat ucky }\end{array}$ & Humid & 1200 & 360 & $\begin{array}{l}\text { Pdilge and } \\
\text { volley } \\
\text { Appon lachian }\end{array}$ & $\begin{array}{l}\text { Weathered } \\
\text { ohale, clay. } \\
\text { and sand }\end{array}$ & $3-5$ & 0.02 & Shale & $\begin{array}{l}\text { Plat. } \\
\text { lying }\end{array}$ \\
\hline $\begin{array}{l}\text { Oak Rldge, } \\
\text { Tennestec }\end{array}$ & Humid & 1300 & 160 & $\begin{array}{l}\text { Aldge and } \\
\text { valley } \\
\text { Appolacti an }\end{array}$ & $\begin{array}{l}\text { Meathered } \\
\text { ohale and } \\
\text { IIII }\end{array}$ & 10 & Vory lon & Strale & Folded \\
\hline $\begin{array}{l}\text { Savannab Riynt, } \\
\text { Sowith farol Ina }\end{array}$ & Humits & 1100 & 0 & $\begin{array}{l}\text { Coastal } \\
\text { plasn }\end{array}$ & $\begin{array}{l}\text { sand and } \\
\text { clay }\end{array}$ & 10 & Vesy tor & $\begin{array}{l}\text { clay, } \\
\text { sand, and } \\
\text { sandetune }\end{array}$ & $\begin{array}{l}\text { Fiate } \\
\text { lying }\end{array}$ \\
\hline $\begin{array}{l}\text { Barnwe1t. } \\
\text { South Caral ina }\end{array}$ & Humid & 2100 & $n$ & $\begin{array}{l}\text { Coastal } \\
\text { platr }\end{array}$ & $\begin{array}{l}\text { Sand and } \\
\text { elay }\end{array}$ & 10 & 0.2 & $\begin{array}{l}\text { Slay, } \\
\text { ontd, and } \\
\text { Eandatone }\end{array}$ & $\begin{array}{l}\text { Plat- } \\
\text { lytug }\end{array}$ \\
\hline $\begin{array}{l}\text { WeBt valley. } \\
\text { New York }\end{array}$ & Humld & 1000 & $30 \mathrm{v}$ & Glacial & $\begin{array}{l}\text { Glacial } \\
\text { orife; alay } \\
\text { alit, and } \\
\text { and }\end{array}$ & $20-30$ & 0.5 & shole & $\begin{array}{l}\text { Flat- } \\
\text { Lying }\end{array}$ \\
\hline $\begin{array}{l}\text { Values used } \\
\text { in RCF }\end{array}$ & Vartable & 500 & 2000 & ----- & $\begin{array}{l}\text { Sand and } \\
\text { clay }\end{array}$ & 10 & n... & -.... & $\begin{array}{l}\text { Flat- } \\
\text { lying }\end{array}$ \\
\hline
\end{tabular}

DoE site 
TABLE F4, Hydrogeologic parameters at existing LLW sites.

\begin{tabular}{|c|c|c|c|c|c|c|c|}
\hline 51te & 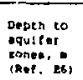 & Trot & $\begin{array}{l}\text { Mestent } \\
\text { uurtage } \\
\text { water } \\
\text { (ante. 25, 26) }\end{array}$ & 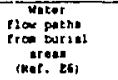 & 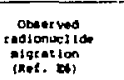 & 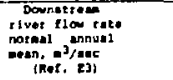 & 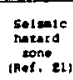 \\
\hline $\begin{array}{l}\text { Huntoro, } \\
\text { Whent ngton" }\end{array}$ & 200 & Gradtent & 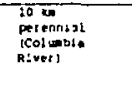 & $\begin{array}{l}\text { rores ath } \\
\text { mand and } \\
\text { gravel }\end{array}$ & $\begin{array}{l}\text { Thatakion } \\
\text { through } \\
\text { uptike is } \\
\text { deep-zooted } \\
\text { plants }\end{array}$ & $\begin{array}{l}\text { Colmble River } \\
\text { Helary oan } \\
5320\end{array}$ & 2 \\
\hline $\begin{array}{l}\text { Rjenlina, } \\
\text { mashingson }\end{array}$ & 100 & Ctodient & $\begin{array}{l}10 \text { un } \\
\text { Peternitl } \\
\text { (Calueble } \\
\text { River) }\end{array}$ & $\begin{array}{l}\text { Unsht ureted } \\
\text { plos in } \\
\text { and and } \\
\text { gravel pored }\end{array}$ & Nor abier vad & $\begin{array}{l}\text { Col mobla hivar } \\
\text { mewary one } \\
5320\end{array}$ & 2 \\
\hline $\begin{array}{l}\text { Aesety. } \\
\text { Mevedn }\end{array}$ & 00 & croolent & 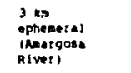 & $\begin{array}{l}\text { Uneaturated } \\
\text { rlow in } \\
\text { cand and } \\
\text { gravel pores }\end{array}$ & Not observed & Mone & ] \\
\hline $\begin{array}{l}\text { Ined, } \\
\text { Intation }\end{array}$ & $60-900$ & Gredient & $\begin{array}{l}3 \text { he } \\
\text { efinteral } \\
\text { (Blg Lost } \\
\text { tofyes }\end{array}$ & $\begin{array}{l}\text { Pored in } \\
\text { and and } \\
\text { gravel }\end{array}$ & $\begin{array}{l}\text { Poseibly by } \\
\text { on-ute } \\
\text { qroundurater }\end{array}$ & $\begin{array}{l}\text { Snake givot } \\
\text { Mager xath, toatro } \\
260\end{array}$ & y \\
\hline 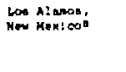 & 200 & Grodient & $\begin{array}{l}\text { l ko } \\
\text { ephenetad } \\
6 \mathrm{~km}\end{array}$ & $\begin{array}{l}\text { gedrosk } \\
\text { frectutes and } \\
\text { gand and } \\
\text { grovel poits }\end{array}$ & $\begin{array}{l}\text { on-zite } \\
\text { vodoes } \\
\text { water zone }\end{array}$ & $\begin{array}{l}\text { Rio Grande kiver } \\
\text { Albuquerque. } \\
\text { Rew Merica } \\
28\end{array}$ & 2 \\
\hline $\begin{array}{l}\text { Eheffield, } \\
\text { I11 those }\end{array}$ & $\begin{array}{l}5-20 \\
100\end{array}$ & $\begin{array}{l}\text { Yesonk } \\
\text { grodzent }\end{array}$ & $\begin{array}{l}\text { slet } \\
\text { boundary } \\
\text { perennisa }\end{array}$ & $\begin{array}{l}\text { Pote opaces } \\
\text { in itil }\end{array}$ & Not oleservad & 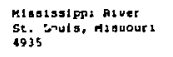 & 1 \\
\hline $\begin{array}{l}\text { Kat thesc. } \\
\text { kant ucky }\end{array}$ & $1-2$ & Vadoue & $\begin{array}{l}500 \pi \\
\text { potentialat }\end{array}$ & $\begin{array}{l}\text { Shale } \\
\text { Iract ure }\end{array}$ & $\begin{array}{l}\text { On and of }- \\
\text { niti ground } \\
\text { end ourface } \\
\text { water }\end{array}$ & $\begin{array}{l}\text { Licking Rlver } \\
\text { Cowlngton, KY } \sim 200 \\
\text { Uhio River } \\
\text { Louldyille, KY }, 2 A=\end{array}$ & 1 \\
\hline $\begin{array}{l}\text { Uik Rlggr: } \\
\text { Tennessee }\end{array}$ & 5 & Vadose & $\begin{array}{l}\text { Onestes } \\
\text { perennial }\end{array}$ & $\begin{array}{l}\text { Shale } \\
\text { frecture } \\
\text { anf pores } \\
\text { in till }\end{array}$ & $\begin{array}{l}\text { On-aite } \\
\text { groundwater } \\
\text { off-site } \\
\text { surface warer }\end{array}$ & $\begin{array}{l}\text { Cltnch River, } \\
\text { Ook Ajdge, Tenn. } \\
\text { Tonnosger River, } \\
\text { Chattanooga } \\
1045 \\
\text { Missisbippi River } \\
\text { Jenphis, Tenn. } \\
13,365\end{array}$ & 2 \\
\hline $\begin{array}{l}\text { Sovarnah River, } \\
\text { South Carolinas }\end{array}$ & $\begin{array}{r}10 \\
200\end{array}$ & $\begin{array}{l}\text { Vadoce } \\
\text { gradient }\end{array}$ & $\begin{array}{l}\text { On-uite } \\
\text { perennial }\end{array}$ & $\begin{array}{l}\text { Pores spaces } \\
\text { In and }\end{array}$ & $\begin{array}{l}\text { On-alte } \\
\text { groundwater }\end{array}$ & $\begin{array}{l}\text { Savannah River } \\
\text { Clyo, Georgia } \\
335\end{array}$ & 2 \\
\hline $\begin{array}{l}\text { Barmuli, } \\
\text { Gouth caroline }\end{array}$ & $\begin{array}{r}10 \\
200\end{array}$ & $\begin{array}{l}\text { Vadore } \\
\text { grondiene }\end{array}$ & $\begin{array}{l}2 \mathrm{~km} \\
\text { potennial } \\
\text { flower } \\
\text { three tus }\end{array}$ & $\begin{array}{l}\text { Pore opeces } \\
\text { in uthd }\end{array}$ & Not obeerved & $\begin{array}{l}\text { Savannah al ver } \\
\text { Clyo. Georgla } \\
335\end{array}$ & 2 \\
\hline $\begin{array}{l}\text { Weat valley, } \\
\text { nerr york }\end{array}$ & $1+20$ & $\begin{array}{l}\text { Vodose } \\
\text { grediont } \\
\text { not } \\
\text { obsez ved }\end{array}$ & $\begin{array}{l}\text { Or-alte } \\
\text { perennilal }\end{array}$ & $\begin{array}{l}\text { Shale } \\
\text { fraceure }\end{array}$ & $\begin{array}{l}\text { On-aite } \\
\text { grounduater } \\
\text { off-site } \\
\text { Eurface water }\end{array}$ & $\begin{array}{l}\text { St. Laurence River } \\
\text { Lake Ontario autlet } \\
\text { 70eo }\end{array}$ & 2 \\
\hline $\begin{array}{l}\text { Vel uep uted } \\
\text { in RSP }\end{array}$ & 18 & Gradient & $\begin{array}{l}1 \text { ke } \\
\text { perenniel }\end{array}$ & $\begin{array}{l}\text { Pares in } \\
\text { soll } \\
\text { underlying } \\
\text { aquiter }\end{array}$ & $\ldots$ & 5320 & $\ldots$ \\
\hline
\end{tabular}

DOE Site 
TABLE F5. Demographic data for existing LLW sites.

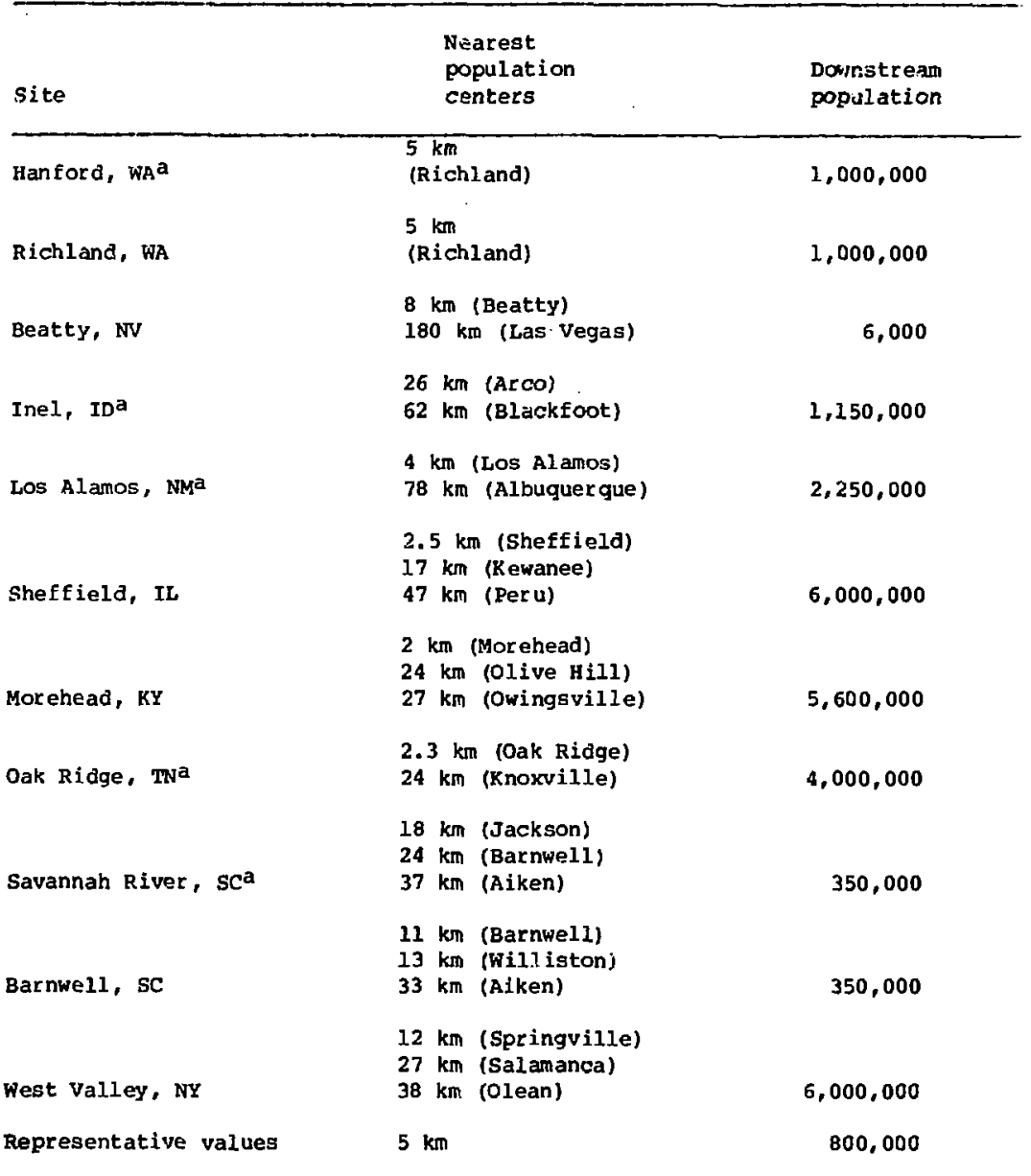

DOE site 
These tables provide a perspective on the RCF that has been mathematically modeled for determining the interfaces of the classification system. Parameters selected for the RCF appear at the bottom of each table. The RCF has been used for predicting radionuclide migration from a typical site to develop acceptable concentration levels in wastes requiring containment. Inclusion of these tables and the RCF parameters in this report should not, however, be construed as either acceptance of current practices or criteria for future confinement facilities. The intent is to provide guidance.

Because the release of radionuclides from a containment facility depends, in part, on the physical form of the waste, some characteristics of currently buried wastes are described in this appendix. LIW are generated in each stage of the nuclear fuel cycle. This study, however, does not include wastes from mining, milling, refining, and enriching operations. These large-volume, low-activity wastes, which generally are not buried, may be the topic of future evaluations. Included in the LWW that we describe here are those generated in fuel fabrication, reactor and reprocessing operations; and cleanup and decommissioning processes, and by non-fuel-cycle sources such as hospitals and industrial users of radioactive materials. Also included are dewatered solids and otherwise solidified LLW.

Decontamination and decomissioning of nuclear facilities produce large items of construction and structural materials that have been contaminated and/or activated during usage. They are currently disposed of by burial, with little packaging other than plastic sheeting.

In addition to the wastes generated in the nuclear fuel cycle, a number of other $\boldsymbol{L}$ w sources exist. Among them are medical, university, and research users of radiation, who send radioactive wastes to burial facilities for disposal. These wastes include animal remains, contaminated glassware and laboratory supplies, failed equipment, trash, and small amounts of excess radioactive isotopes. 
In the past, the radioactivity in wastes at the comercial sites has been characterized largely by use of broad categorles such as special nuclear materials, source materials, and byproduct materials for fissile, fertile, and fission and activation products, respectively. Tables 66 through Flo use these categories to sumarize the data for existing sites. 
TABLE F6. Average concentration, $\mathrm{Ci} / \mathrm{m}^{3}$ of LLW buried at commerciai sites, 1963 through 1976.

\begin{tabular}{|c|c|c|c|c|c|c|c|c|c|c|c|c|c|c|c|}
\hline \multirow[b]{2}{*}{ site } & \multicolumn{11}{|c|}{ Year } & \multirow[b]{2}{*}{1974} & \multirow[b]{2}{*}{1975} & \multirow[b]{2}{*}{1976} & \multirow[b]{2}{*}{ Average } \\
\hline & 1963 & 1964 & 1965 & 1966 & 1967 & 1968 & 1969 & 1970 & 1971 & 1972 & 1973 & & & & \\
\hline $\begin{array}{l}\text { Barnwell, } \\
\text { South Cacolins }\end{array}$ & -- & - & - & - & - & -- & -- & -- & 3.52 & 0.27 & 2.68 & 18.03 & 0.96 & 0.97 & 4.91 \\
\hline $\begin{array}{l}\text { Beatty, } \\
\text { Nevada }\end{array}$ & 1.62 & 2.28 & 3.21 & 3.39 & 3.39 & 1.90 & 2.28 & 2.98 & 1.20 & 1.22 & 1.40 & 5.83 & 4.40 & 1.16 & 2.49 \\
\hline $\begin{array}{l}\text { Morehead, } \\
\text { Rentucky }\end{array}$ & 10.2 & 38.3 & 11.1 & 9.5 & 5.4 & 5.6 & 3.0 & 3.8 & 54.6 & 13.9 & 11.7 & 16.9 & 16.9 & 15.3 & 16.0 \\
\hline $\begin{array}{l}\text { Rlchland, } \\
\text { Nashington }\end{array}$ & -- & -- & 0.22 & 0.42 & 6.18 & 15.4 & 128.0 & 125.0 & 11.0 & 48.6 & 55.2 & 8.63 & 75.5 & 36.4 & 34.6 \\
\hline $\begin{array}{l}\text { Sheffleld, } \\
\text { Illinois }\end{array}$ & - & -- & - & -- & 1.52 & 0.88 & 1.09 & 1.92 & 1.78 & 0.62 & 0.28 & 0.26 & 0.43 & 0.57 & 0.67 \\
\hline $\begin{array}{l}\text { Weat valley, } \\
\text { New York }\end{array}$ & 2.63 & 1.78 & 4.56 & 8.74 & 10.35 & 11.46 & 5.44 & 7.12 & 6.57 & 8.67 & 22.74 & 6.47 & 5.01 & -- & 8.66 \\
\hline Aversge & 1.77 & 12.68 & 7.01 & 6.59 & 5.86 & 5.94 & 5.72 & 6.15 & 27.4 & 8.62 & B.44 & 10.66 & 1.98 & 5.66 & e. $\therefore$ ? \\
\hline
\end{tabular}


TAELE F7. Byprodunt material buried at LLW sites from 1962 through 1976.

\begin{tabular}{|c|c|c|c|c|c|c|c|c|c|c|c|c|c|c|c|c|}
\hline \multirow[b]{2}{*}{ site } & \multicolumn{16}{|c|}{ Year } \\
\hline & 2962 & 1963 & 1964 & 1965 & 1966 & 1967 & 1968 & 1969 & 1970 & 1971 & 1972 & 1973 & 1974 & 1975 & 1876 & Total \\
\hline \multicolumn{17}{|l|}{ Barmell, } \\
\hline \multicolumn{17}{|l|}{ South Caroling } \\
\hline volume, $e^{3}$ & - & -- & - & --- & -- & -- & $\cdots$ & -- & - & 1,171 & 3.757 & 15,839 & 28,244 & 18,072 & 28,829 & 85.912 \\
\hline curien & - & - & -- & -- & -- & -- & $\cdots$ & --- & $-*$ & 1,118 & 997 & 42,500 & 329,043 & 17.420 & 27.890 & 121.988 \\
\hline \multicolumn{17}{|l|}{ Deatty, } \\
\hline \multicolumn{17}{|l|}{ Nerndh } \\
\hline rolune, ${ }^{3}$ & 1,060 & 3,510 & 2,840 & 1,990 & 3,530 & 3,210 & 3,580 & 2,460 & 4,130 & $? 580$ & 1,300 & 4.080 & $t, 100$ & 4,279 & 3.864 & 53,017 \\
\hline Corien & -- & 5.690 & 6,477 & 6,377 & 11.974 & 10,894 & 6,800 & 9,761 & 12,304 & +116 & 5,228 & 5.704 & 23,901 & 19,389 & 4.493 & 123,119 \\
\hline \multicolumn{17}{|l|}{ Mor thead, } \\
\hline \multicolumn{17}{|l|}{ Rentucky } \\
\hline mine, ${ }^{3}$ & $-r$ & 2,210 & 3,070 & 5,750 & 5,360 & 7,820 & 8,180 & 10,400 & 12,500 & 13.200 & 15,800 & 10.200 & 8.520 & 17.098 & 11,783 & 134,591 \\
\hline curies & $-\infty$ & 22,716 & 147,322 & 63,028 & 52,729 & 42,200 & 45,578 & 31,027 & $16,96 \mathrm{~A}$ & 720,146 & 217,350 & 126,374 & 143,696 & 289,581 & 211,356 & $2.151,802$ \\
\hline \multicolumn{17}{|l|}{ RIchland, } \\
\hline washington & & & & & & & . & & & & & & & & & \\
\hline rolume, $\mathbf{a}^{3}$ & -- & -- & -- & 670 & 2,400 & B70 & 670 & 440 & 120 & 580 & 680 & 1,033 & 1,110 & 1.500 & 2,867 & 13,520 \\
\hline curies & - & -- & -- & 144 & 1,006 & 5,370 & 10,330 & 55,964 & 52,020 & 23,916 & 31,809 & 57,037 & {$[2,[7]$} & 113.341 & 104,306 & 404,224 \\
\hline \multicolumn{17}{|l|}{ shoteield, } \\
\hline \multicolumn{17}{|l|}{ Illinols } \\
\hline moluee, $s^{3}$ & -- & -- & -- & $m$ & -- & 2,530 & 2,710 & 2,010 & 2,930 & 4,430 & 5,960 & 0.530 & 12.400 & 24,112 & 13,480 & 68.992 \\
\hline curiet & $\cdots$ & -- & -- & $\cdots$ & -- & 3.850 & 2.381 & 2,192 & 5,425 & 7,093 & 0,857 & 2,004 & 3,229 & 6,104 & 2,764 & 46,513 \\
\hline \multicolumn{17}{|l|}{ Weat valley, } \\
\hline \multicolumn{17}{|l|}{ New York } \\
\hline molue, $x^{3}$ & - & 520 & 6,390 & 4,720 & 1,700 & 4,950 & 1.500 & 4.270 & 3,100 & 6,360 & 7.060 & 7,500 & 8,540 & 2,049 & $m$ & 66,726 \\
\hline curles & $-\cdots$ & 1,372 & 11,355 & 21.515 & $\$ 1,056$ & 51.230 & 51,675 & 23,264 & 16,241 & 42,458 & 01.200 & 170,552 & 55,505 & 10.273 & $\cdots$ & 577.754 \\
\hline \multicolumn{17}{|l|}{ Total } \\
\hline wollee, $\mathbf{1}^{3}$ & 1,860 & 6,210 & 13,100 & 13,100 & 16,200 & 19,400 & 19,600 & 21.400 & 25,000 & 29,301 & 37,285 & 47,046 & 33,242 & 57.010 & 62,023 & 022.607 \\
\hline curtex & -- & 29,778 & 166,154 & 91,874 & 105,769 & 113.832 & 116,772 & 122,209 & 153,810 & 002,049 & 321,449 & 306.901 & 567,510 & 455,098 & 355,789 & $3,000,540$ \\
\hline
\end{tabular}


TABLE F8. Special nuclear materials (fissile materials) buried at LLW sites.

\begin{tabular}{|c|c|c|c|c|c|c|c|c|c|c|c|c|c|c|c|c|}
\hline \multirow[b]{2}{*}{ site } & \multicolumn{13}{|c|}{ Year } & \multirow[b]{2}{*}{ i975 } & \multirow[b]{2}{*}{1976} & \multirow[b]{2}{*}{ tot $\Perp 1$} \\
\hline & 1962 & 1963 & 1964 & 1965 & 2966 & 1967 & 1968 & 1969 & 1970 & 1971 & 1972 & 2973 & 1774 & & & \\
\hline \multicolumn{17}{|c|}{ Barnwe:.1, } \\
\hline g & -- & -- & - & -- & - & - & -- & -- & - & 13.220 & 46,718 & 94.800 & 110.444 & 64,425 & 92.800 & 427.407 \\
\hline $9 / a^{3}$ & -- & -- & + & -- & -- & -- & $\cdots$ & -. & - & 13.3 & 12.4 & 6.30 & 0.05 & 3.36 & 3.22 & 1.67 \\
\hline \multicolumn{17}{|l|}{ Beatty, } \\
\hline \multicolumn{17}{|l|}{ Nevada } \\
\hline g & 319 & 41,304 & 172,030 & 324,752 & 5,872 & 22,644 & 8,602 & 5.095 & 7.700 & 757 & $21 .: 21$ & 15,264 & 16.934 & 29,276 & 2,096 & 603,670 \\
\hline $9 / 0^{3}$ & 0.17 & 11.6 & 60.6 & 168 & 1.66 & 7.05 & 2.40 & 1.17 & 1.07 & 0.21 & 4.92 & 3.72 & 4.14 & 7.01 & 0.54 & 12.49 \\
\hline \multicolumn{17}{|c|}{ Morehesd, } \\
\hline \multicolumn{17}{|c|}{ Kentucky } \\
\hline 9 & - & 959 & 11.889 & 4,261 & 1,462 & 14.812 & 17,71 & 31.506 & 47,562 & $7 . .770$ & 71,463 & 46.244 & 23.832 & 23.690 & 27.474 & 403.705 \\
\hline $9 / m^{3}$ & - & 0.43 & 3.07 & 0.74 & 3.34 & 1.90 & 2.17 & 3.03 & 3.80 & 5.51 & 4.58 & 4.58 & 2.00 & 1.50 & 1.99 & 3.00 \\
\hline \multicolumn{17}{|c|}{$\begin{array}{l}\text { Rithlend, } \\
\text { Washington }\end{array}$} \\
\hline g & -- & -- & -- & 3 & 1,418 & 0.16 & 0.27 & 32 & 200 & 15 & 832 & 6.536 & 4.004 & 18,978 & 24.378 & 37.290 \\
\hline $9 / x^{3}$ & - & - & -- & $4.0-3$ & 0.59 & $2.0-4$ & $4.04-4$ & 0.07 & 0.47 & 0.03 & 1.27 & 6.15 & 3.46 & 12.63 & 0.50 & 4.26 \\
\hline \multicolumn{17}{|c|}{ Sheffield, } \\
\hline \multicolumn{17}{|c|}{ Ill Lnols } \\
\hline 9 & -- & - & - & - & -- & 1,238 & 1.754 & 3,843 & 5.649 & 9.934 & 5,898 & 6.126 & 6,190 & 3,265 & $1,+36$ & $(7,66\}$ \\
\hline$g / m^{3}$ & - & - & - & -- & - & 0.49 & 0.65 & 1.91 & 2,0 & 2.24 & 0.99 & 0.72 & 0.50 & 0.37 & 0.13 & 0.69 \\
\hline \multicolumn{17}{|c|}{$\begin{array}{l}\text { West valley, } \\
\text { Wew York }\end{array}$} \\
\hline 9 & -- & 952 & 3,273 & 2,433 & 1,999 & 3,446 & 2,045 & $.7,301$ & 9,273 & A. B:6 & $T .321$ & 7.710 & 2.984 & - & -- & 36,003 \\
\hline$g / \Delta^{3}$ & - & 1.92 & 0.51 & 0,52 & 1.05 & 0.70 & 0.45 & 1.71 & 1.62 & 0.76 & 1.04 & 1.03 & 0.35 & - & - & 0.84 \\
\hline \multicolumn{17}{|l|}{ Total } \\
\hline 9 & 319 & $₫ 3,215$ & 187,192 & 341,459 & 19,751 & 12,170 & 30,172 & 47,687 & 69,392 & 101.512 & 153,389 & 181,107 & 186,296 & 143,654 & 248,486 & $1.675,801$ \\
\hline$g / m^{3}$ & 0.27 & 6.93 & 14.29 & 26.06 & 1.22 & 2.17 & 1.54 & 2.23 & 2.78 & 3.16 & 4.11 & 3.95 & 3.12 & 2.52 & 2.36 & 3.97 \\
\hline
\end{tabular}


TABLE F9. Source naterial (nonfissile uraniun and thorium) buried at comercial sites.

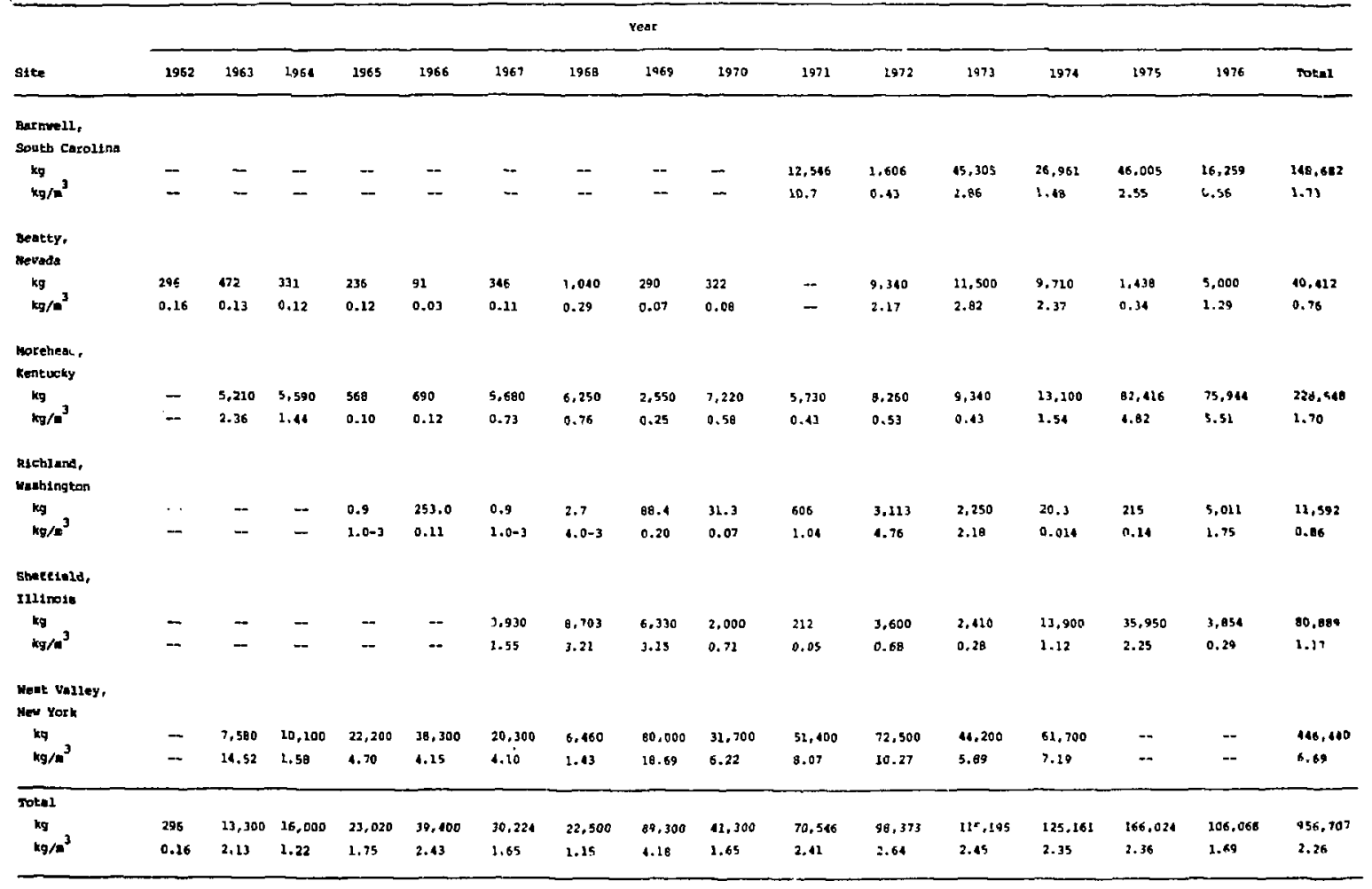


TABLS FlO, Inventory of nuclides as buried at INEL.

\begin{tabular}{|c|c|c|c|}
\hline \multirow[b]{2}{*}{ Nuclide } & \multirow[b]{2}{*}{ Half-life, d } & \multicolumn{2}{|c|}{ Percentage of curle activity } \\
\hline & & 1974 & 1975 \\
\hline${ }^{144} \mathrm{Ce},{ }^{144} \mathrm{Pr}$ & 285 & - & 4.38 \\
\hline${ }^{144} \mathrm{Ce}$ & 285 & 4.19 & $3.0 \%$ \\
\hline${ }^{60} \mathrm{Co}$ & 1,920 & $38.8 \%$ & $55.3 \%$ \\
\hline${ }^{51} \mathrm{Cr}$ & 28 & 0.48 & 1.78 \\
\hline${ }^{134} \mathrm{CB}$ & 770 & 0.38 & 0.38 \\
\hline${ }^{137} \mathrm{Cs}$ & 10,877 & 7.28 & 4.38 \\
\hline${ }^{154} \mathrm{Eu}$ & 5,840 & 0.28 & 0.38 \\
\hline${ }^{155} \mathrm{Eu}$ & 661 & 0.18 & 0.28 \\
\hline${ }^{55} \mathrm{Fe}$ & 880 & -- & 2.78 \\
\hline${ }^{59} \mathrm{Fe}$ & 45 & 7.38 & 1.58 \\
\hline MAP & -- & 0.58 & 0.18 \\
\hline MFP & - & 3.88 & 2.28 \\
\hline $54 \mathrm{Mn}$ & 312 & 0.48 & 2.88 \\
\hline $56 \mathrm{Mn}$ & 0.1 & - & 4.28 \\
\hline${ }^{59} \mathrm{Ni}$ & $29,000,000$ & 16.28 & - \\
\hline $238 \mathrm{Pu}$ & 31,536 & 1.68 & -- \\
\hline${ }^{86} \mathrm{Rb}$ & 19 & 0.38 & -- \\
\hline${ }^{106} \mathrm{Ru},{ }^{106} \mathrm{Rh}$ & 369 & 0.38 & 0.68 \\
\hline${ }^{106} \mathrm{Ru}$ & 369 & 1.78 & 1.38 \\
\hline${ }^{125} \mathrm{Sb}$ & 486 & 0.58 & 0.68 \\
\hline${ }^{90} \mathrm{Sr},{ }^{90} \mathrm{Y}$ & 10,439 & 5.58 & 11.78 \\
\hline${ }^{90} \mathrm{Sr}$ & 10,439 & B. 08 & 1.68 \\
\hline Unident. $B+Y$ & - & 0.18 & 0.18 \\
\hline${ }^{65} \mathrm{Zn}$ & 245 & 1.88 & -- \\
\hline${ }^{95} \mathrm{Ar},{ }^{95} \mathrm{Nb}$ & 65 & 0.88 & 0.98 \\
\hline Total curies buried, Ci & & 19,770 & 13,190 \\
\hline Total volume buried, $\mathrm{m}^{3}$ & & 3,694 & 5,685 \\
\hline
\end{tabular}


Table Flo lists nuclide-specif lc data from the Idaho National Engineering Laboratory (INEL) for 1974 and 1975. The wastes were generated during all phases of the fuel cycle after irradiation in test reactors. It is expected that the activity and concentration ratios for these wastes are generally typical of LLW. No other nuclide-specific data characterizing ILW is readily available. This table has been included only for perspective concerning the nuclide content of typical wastes. 


\section{REFERENCES}

F1. J. E. Dieckhoncr, "Sources, Production Rates and Characteristics of ERDA Low-Level wastes," in Proc. Symp. On the Management of Low-Level Radioactive Waste, Atlanta, Ga. (1977) .

F2. U.S. Enorgy Research and Development Administration, Alternatives for Managing Wastes from Reactors and Post-Fission Operations in the LWR Fuel Cycle, Washington, D.C., Report ERDA 76-43, Vol. 1 (1976).

F3. ए.S. Energy Research and Development Administration, Final Environmental Statement on Waste Management Operations at the INEL, Report ERDA-1536 (1977).

F4. U.3. Nuciear Regulatory Commission, NRC Task Forze Report on Review of the Federal/state Program for Regulation of Commercial Low-Level Radioactive Waste Burial Grounds, Washington, D.C., Report NUREG-0217 (1977).

F5. M. F. O'Connell and W. F. Holcomb, "A Summary of Low-Level Radioactive Wastes Buried at Compercial Sites Between 1962-1973, with Projections to the Year 2000," Radiation and Data Reports (December 1974).

F6. Proc. Symp. on Management of Wastes from The LhR Fuel Cycle, CONF-76-0701, Denver, Colo. (July 1976).

F7. The Shallow Land Burial of Low-Level Radioactivity Contaminated Solid Waste, Panel on Land Burial, Committee on Radioactive Waste Management, Commisssion on Natural Resources, National Research Council, National. Academy of sciences, washington, D.C. (1976). 


\section{APPENDIX G \\ REFERENCE CONTAINMFNT FACILITY DETAILS}

The RCF is based on shallow land burlal. Nonetheless, selection of appropriate parameters makes the methodology suitable for calculations based on other disposal methods. A list of design assumptions and criteria was put togetner for the R:F used in the analyses. The following items have been assumed as typical of future waste-disposal facilities and appropriate for the RCF :

- The facility will use shallow land burial in open pits, covering the waste as filled with overburden removed during excavation.

- The wastes will arrive at the facility in DOT-approved shipping containers suitable for burial and sized for conventional materials-handling equipment.

- Wastes will be solidified at their source before shipment. No provisions will be made for handling liquid radioactive wastes at the RCF.

- A 121 hectare (300-acre) site will be considered. It is assumed to be in a semiarid locale, $5 \mathrm{~km}$ from a major highway, $2 \mathrm{~km}$ from a railroad main line, and $1 \mathrm{~km}$ from a large river. It is also assumed that between one-half and two-thirds of the total land area will be used for burial. The remaining area will allow for open terrain, structures, service roads, and highway and railroad access areas.

- The site will be fenced with an intcusion alarm to prevent unacithorized entry.

- Permanent identification markers will be used to locate burial trench boundaries.

- Wastes will be covered with soil every day.

- Migration of radioacti"e material will be monitored before, during, and after the operational phases of the facility. 
- After the site is filled, unnecessary structures will be removed. The area will then be graded and seeded for erosion control, and a perpetual maintenance progran will be established.

- A 40-y operational lifetime for burial operations is assumed. Institutional control and surveillance of the site will be maintained for as long as a few hundred years.

- About two-thirds of the trench volume is assumed to consist of soil mixed between waste containers as the trenches are filled.

- When calculating the concentrations in human exposure pathways, no credit will be taken for the retention of radionuclides in the buried containers.

Total site capacity is $569,000 \mathrm{~m}^{3}$ of waste when 100 typical trenches are filled to capacity with wastes. This total is about $14,000 \mathrm{in}^{3}$ per year for a 40-y facility lifetime. At a uniform $E$ ill rate, about two hundred and eighty 55-gal drums per day are needed to fill the site in $40 y$. This capacity is enough to handle the wastes projected to be yenerated by about $2000 \mathrm{GW}(e)-y$ of nuclear power production.

Table GL lists the factors used to arrive at the unit costs of $\$ 100 / \mathrm{m}^{3}$ of waste disposed. The costs are consistent with charges now assessed by commercial site operators across the country.

These data have been used as input for the cost-benefit analysis to evaluate cost-effectiveness as a function of interface level. 
TABLE G1. Cost factors for RCF.

Capital

Site acquisition and development

$3,500,000$

structural construction

$1,200,000$

site preparation

230,000

operating equipment

$1,140,000$

operationg costs

Labor

$$
\begin{array}{r}
367,500 / y \times 40 y \\
7,000 / y \times 40 y \\
20,000 / y \times 40 y
\end{array}
$$

$14,700,000$

Supplies

280,000

Materials

800,000

Enviconmental impact statement

500,000

Architect-engineering

210,000

site maintenance and perpetual care

770,000

Net costs

$23,330,000$

Financing charges

$28,200,000$

Total costs

$51,530,000$

Site capacity $569,000 \mathrm{~m}^{3}$

Unit costs $\$ 90 / \mathrm{m}^{3}$ Consider contingencies to make $\$ 100 / \mathrm{m}^{3}$ cost-effective. 


\section{APPENDIX H}

CALCULATIONS FOR AIRBORNE RELEASES

When determining the allowable concentration limits in the waste to be placed in the low-level burial RCF, we considered various potential airborne releases to identify limiting cases. Two potential occurrences that lead to liniting values of concentration are (1) an accident resulting in the release of a fraction of the contents of a barrel during the burial operation, and (2) the reclamation of land used as a burial site following loss of institutional control of the site after a few hundred years. The first case sets a limit on concentration considering both short and long half-life elements. The second case sets a limit based mainly on long half-life elements. In addition to these two cases, a continuous release was also investigated.

\section{SINGLE-BARREL ACCIDENT SCENARIO}

It is assumed that LLW will be packaged for disposal in 55-gal drums or barrels, as is the present practice. The single-barrel accident is defined as the instantaneous release of a fraction of the contents of a barrel during the burial operation. The main pathway of concern for dose to the off-site population is the airborne transport of the material released from the barrel. For this analysis, the following conservative yet realistic assumptions have been made:

- For the release, 0.1\% of the barrel contents becomes airborne.

- A standard man is on the plume center line at the site boundary $160 \mathrm{~m}(0.1 \mathrm{mi})$ from the source. He is engaged in light activity (20 1/min respiration rate).

- A Pasquill F stability level is used.

- The dose to any organ should not exceed $0.5 \mathrm{rem} / \mathrm{y}$.

The concentration at the plume centerline for an instantaneous point source released at the surface is given by: 


$$
x(x, y, z, t)=\frac{Q(2)^{-1 / 2}(\pi)^{-3 / 2}}{\sigma_{x} \sigma^{\sigma} z} \exp \left[-\frac{(x-\bar{u} t)^{2}}{2 \sigma_{x}^{2}}\right]
$$

where

$$
\begin{aligned}
x(x, y, z, t) & =\text { concentration, } \mathrm{Ci} / \mathrm{m}^{3} \\
Q & =\text { source strength, } \mathrm{Ci} \\
\sigma_{x}, \mathrm{O}_{y}, \sigma_{z} & =\text { dispersion coef fecients, } \mathrm{m} \\
\frac{\mathrm{u}}{} & =\text { average wind speed, } \mathrm{m} / \mathrm{sec} \\
\mathrm{x} & =\text { direction of plume axis (wind). }
\end{aligned}
$$

This equation is integrated to get the center-line concentration-time exposure

$$
I=\int_{0}^{\infty} x d t=\frac{Q}{\pi \sigma_{y} \sigma_{z} \bar{u}} \frac{C i-s e c}{m^{3}}
$$

For an $F$ stability level, $\sigma_{y} \cong 7, \sigma_{z} \cong 3,5$, and using

$$
\begin{aligned}
& \overline{\mathrm{u}}=1.56 \mathrm{~m} / \mathrm{sec}(3.5 \mathrm{mph}), \\
& \bar{I}=8.33 \times 10^{-3} \mathrm{Q} \frac{\mathrm{Ci}-\mathrm{sec}}{\mathrm{m}^{3}}
\end{aligned}
$$

Some of the activity released in an accident will fall out in the immediate vicinity and not reach the perimeter fence. To be conservative, however, we assume that all the activity that becomes airborne reaches the location of our maximum individual lccated directly downwind $160 \mathrm{~m}$ from the site of the accident. The amount of radioactivity he inhales is the product of the intergrated concentration at that location and his respiration rate. Thus, the amount inhaled is

$$
\begin{aligned}
I_{0} & =\left(8.33 \mathrm{E}-03 \mathrm{Q} \frac{\mathrm{ci-sec}}{\mathrm{m}^{3}}\right)\left(20 \frac{\mathrm{l}}{\mathrm{min}}\right)\left(10^{-3} \frac{\mathrm{m}^{3}}{1}\right)\left(\frac{1 \mathrm{~min}}{60 \mathrm{sec}}\right) \\
& =2.8 \mathrm{E}-06 \mathrm{~g} \mathrm{Ci} .
\end{aligned}
$$


The acceptable dose to an organ at risk from internally deposited

radioactivity was $0.5 \mathrm{rem} / \mathrm{Y}$. Appendix $\mathrm{B}$. Table $\mathrm{II}$, of $10 \mathrm{CFR} 20$ shows that ${ }^{239}{ }^{\text {ru }}$ in soluble form is the most radiotoxic isotope listed, ${ }^{*}$ with a maximum permissible concentration of $6 \times 10^{-14} \mu \mathrm{Ci} / \mathrm{cm}^{3}$.

The exposure to the organs of the body was calculated with the LLL AERIN computer code. This code tracks the radionuclide from the moment of initial deposit in the body through the translocation pathways to various organs of the body, calculating the dose to the organs as a function of time. The code accepts intake into the body of any nuclide as a single acute exposure, as a series of acute exposures received at any selected time intervals, or as a continuous exposure of varying concentrations.

The code was developec mainly for inhalation exposures, but it can be used to describe other modes of intake by altering certain constants (i.e., mass of organs, fractions of the radionuclide moving to and from the blood, biological half-life of the radionuclide in the organs, and so forth\}.

In the case of plutonium inhalation, the code uses the ICRP Lung Model. The particle size of the inhaled nuclide is an important parameter in this model.

Table H1, resulting from the AERIN Code runs for soluble and insoluble ${ }^{239} \mathrm{Pu}$ of different particle sizes, shows the value of $I_{0}$ necessary to give a maximum organ dose of $0.5 \mathrm{rem} / \mathrm{y}$.

\footnotetext{
${ }^{\star 248} \mathrm{Cm}$ is the single exception. The MPC for it is $2 \times 10^{-14} \mu \mathrm{Ci} / \mathrm{cm}^{3}$; however, the quantity of this isotope in waste will $k$ : very much less than one third the quantity of ${ }^{239} \mathrm{pu}$. Therefore, we shall use ${ }^{239} \mathrm{Pu}$ in the calculation of internal dose to our maximum exposed individual.
} 
TABLE Hl. Values of $I_{o}$ in $\mu \mathrm{Ci}$ to give $0.5 \mathrm{rem} / \mathrm{y}$ maximum dose to body organ indicated for inhalation of soluble and insoluble ${ }^{239} \mathrm{Pu}$.

Particle size (AMAD); $\mu \mathrm{m}$

$\begin{array}{llll}\text { Organ } & 0.1 & 1.0 & 5\end{array}$

\begin{tabular}{|c|c|c|c|c|c|c|c|c|}
\hline \multirow[t]{2}{*}{ Bone } & $8.2 z-03$ & $(s)^{a}$ & 9.8 & $E-03$ & (S) & B. 2 E-03 & (S) & 8.2 E-03 \\
\hline & 1.4 E-02 & (I) & 2.6 & $E-02$ & (I) & 4.1 E-02 & (I) & $5.3 \mathrm{E}-U \angle$ \\
\hline \multirow[t]{2}{*}{ Lung } & $5.1 E-03$ & (S) & 1.1 & $E-02$ & (S) & 2.1 E-02 & (S) & $3.2 \mathrm{E}-02$ \\
\hline & $1.3 E-03$ & (I) & 2.7 & E-03 & (I) & 5.4 E-03 & (I) & B.1 E-03 \\
\hline
\end{tabular}

${ }^{a_{S}}=$ Soluble "W" class; $I$ = Insoluble "Y" class

Particle sizes in Table $\mathrm{H}$ J are normalized to an activity median aerodynamic diameter (AMAD). From stokes' law on the terminal velocity of particles settling in a medium, the approximate AMAD of a particle with density $\rho$ can be given by

$$
\text { AMAIJ }=D\left(\frac{\rho-\rho_{0}}{1-\rho_{0}}\right)^{1 / 2}
$$

where $D$ is the physical diameter of the particle in question and $\rho_{0}$ is the density of the medium.

For example, a 1- $\mu$ m-diameter particle of $\mathrm{P}^{\prime} \mathrm{O}_{2}$, which has a density of $11.46 \mathrm{~g} / \mathrm{cm}^{3}$, would have an AMAD of $3.4 \mu \mathrm{m}$ in air. A reasonably conservative assumption for particle size in the accident scenario would be 1 uM ANAD.

From Table $\mathrm{Hl}$, the most restrictive value of $I_{0}$ for a $1 \mu \mathrm{m}$ AMAD is 2.7 E-03 $\mu \mathrm{Ci}$. Using equation (H4) we solve for $Q$ and get

$$
\mathrm{Q}=\frac{2.7 \mathrm{E}-03}{2.8 \mathrm{E}-06} \quad \mu \mathrm{Ci}=1 \mathrm{E}+03 \mu \mathrm{Ci}
$$


Thus, the maximum release of ${ }^{239} \mathrm{Pu}$ should not exceed $1 \mathrm{E}+03$ uCl if exposure of the maximum exposed individual at the perimeter fence is not to exceed $0.5 \mathrm{rem} / \mathrm{y}$.

If we assume that the waste container is a 55-gal drum (volume $-0.208 \mathrm{~m}^{3}$ ) and that 0.18 of the barrel contents becomes airborne as a result of the accident, then the maximum concentration (MC) of ${ }^{239} \mathrm{Pu}$ permitten in the barrel is:

$$
\begin{aligned}
& M C_{\text {(waste) }}=\frac{1.0 \mathrm{E}+03 \mu \mathrm{Cl}}{0.1 \mathrm{E}-02 \times 0.208 \mathrm{E}+06 \mathrm{~cm}^{3}} \\
& M C_{\text {(waste) }}=4.8 \mu \mathrm{Ci} / \mathrm{cm}^{3} .
\end{aligned}
$$

The objectives of this study do not include determination of the correct or appropriate guidelines for acceptable risk. We have used $0.5 \mathrm{rem} / \mathrm{y}$ on the basis of present regulatory guides. The value is used to illustrate the applicability of the methodology for qualifying the wc system interfaces. other guidelines could be used and the results will scale proportionally to the limiting dose accepted.

CONTINUOUS AIRBORNE SCENARIO

The effect of a continous airborne source model was considered in determining Iimiting cases. We developed a scenario in which natural erosion has exposed the buried waste. The radioactive nuclides are resuspended, and they contaminate the air downwind of the RCF. Populations of the public are continuously exposed by inhaling the contaminated air. In developing the calculations for this scenario, we shall assume that our RCF of 120 hectares is a plot $1200 \mathrm{~m}$ by $1000 \mathrm{~m}$ and that one-half of this land area was used to bury the radioactive waste. The concentration of radioactivity in the soil of the buried waste is $\left\langle Q_{B} / 30\right\rangle \mu \mathrm{Ci} / \mathrm{Cm}^{3}$, where $Q_{B}$ is the maximum concentration of the activity permitted in the waste container at the time of burial. The factor 30 is the product of the soil dilution (3) and the peak-to-average ratio $(10)$. 
The average long-term soil erosion rate of $25 \mathrm{~g} / \mathrm{m}^{2}-\mathrm{y}$ will be assumed. He shall assume also that this is the rate for wind erosion alone.

After enough time, the natural eroding forces of wind and water will expose the contents of the burial site. It is mos: unlikely that exposure would occur during the $100 \mathrm{y}$ of institutional control. In fact, it is reasonable to believe that many years will pass after controls are removed before erosion will work down the overburden to expose the radioactivity. Only radionuclides with long half-lives will still be present. We shall assume that the exposed radioactivity is ${ }^{239} \mathrm{Pu}$ and that no radioactive decay has occurred since burial. The source term then is given by the following equation:

$$
Q=\left(\frac{Q_{B}{ }^{\mu C i}}{30}\right)\left(\frac{25 g}{m^{2}}\right)\left(\frac{A m^{2}}{\rho g / \mathrm{cm}^{3}}\right) 10^{-6} \frac{C i}{\mu C i}
$$

where

$$
\begin{aligned}
A= & \text { surface area of exposed waste material }=1.2 \times 10^{6} \times 0.5 \\
& \text { or } 6 \times 10^{5} \mathrm{~m}^{2} \\
\rho= & \text { density of soil }=2 \mathrm{~g} / \mathrm{cm}^{3} .
\end{aligned}
$$

The source term then is

$$
\mathrm{Q}=0.25 \mathrm{Q}_{\mathrm{B}} \mathrm{Ci} / \mathrm{Y} \text { or } 7.9 \times 10^{-9} \mathrm{Q}_{\mathrm{B}} \mathrm{Ci} / \mathrm{sec} \text {. }
$$

Pasquill's continuous point-source diffusion equation for a surface release is:

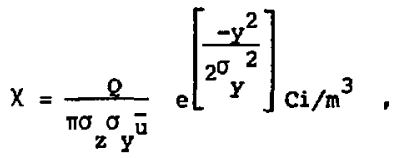

where $\sigma_{z}$ and $\sigma_{y}$ are the standard deviations of the distribution of material in a plume in the vertical and srosswind directions, respectively. Their values are functions of the downwind distance, $x_{p}$ from the point of release and the stability of the atmosphere into which the material is released.

To obtain a value of $\chi$ downwind from an area source we take advantage of the proper ty that Gaussian diffugion models possess--if the source and the receptor 
locations are interchanged, the numerical value of the concentration, $X$, is not affected. This means that the concentration at a point downind from a number of sources can be computed by assuming that all the sources are combined at the receptor point and by suming the computed values of $x$ at the actual source points.

To apply this in the solution of an area source, we assume that the area is made up of $n$ crosswind strip sources of length $2 y$. The receptor point, $R$, is $x$ meters downwind from the near edge of the source area as sketched.

Area source

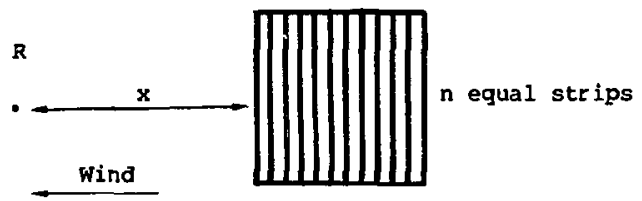

Thus, the concentration, $x$, at $R$ is the sum of the contribution of each strip source and is given by the equation,

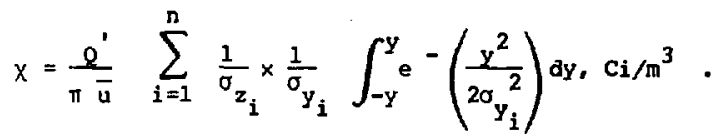

$Q^{\prime}$ has been redefined as the actvity per unit length emitted per unit time along each strip, or,

$$
Q^{\prime}=Q / 2 y, C i / m-s e c
$$

where $n$ is the number of strips chosen to represent the area of the RCF. Thus,

$$
Q^{\prime}=\frac{7.9 \times 10^{-9} Q_{B} C i / s e c}{1.2 \times 10^{3}}=6.6 \times 10^{-12} Q_{B} / n, C x / m-s e c .
$$


The solution of

$$
\int_{-y}^{y} e^{-\left(\frac{y^{2}}{2 \sigma_{y}^{2}}\right)} d y
$$

is obtained from the table of normal probability function for each value of $\sigma_{y}$.

We assumed that (1) the exposed public was located $1 \mathrm{~km}$ downwind from the nearest edge of the RCF, (2) the average wind velocity over $50 \mathrm{y}$ was $3.5 \mathrm{mph}$, and (3) the average Pasquil stability category was " $D$ " or neutral. These are conservative values. Higher wind velocity or more instability in the lower atmosphere will lower the 50-y dose commitment for a given source term.

Setting $n$ equal to 50 , we obtain

$$
Q^{\prime}=\frac{6.6 \times 10^{-12} \mathrm{Q}_{\mathrm{B}}}{50}=1.3 \times 10^{-13} \mathrm{Q}_{\mathrm{B}^{\prime}} \mathrm{Ci} / \mathrm{m}-\mathrm{sec} .
$$

The solution of

$$
\sum \frac{2}{\sigma_{z} \sigma_{y}} \int_{0}^{y} e^{-\left(\frac{y^{2}}{2 a_{y}^{2}}\right) d y}
$$

yielded a value

$$
3.35 \times 10^{-2}, \mathrm{~m}^{-1} \text {. }
$$

Therefore, from equation H5,

$$
\begin{aligned}
& X=\frac{1.3 \times 10^{-13} \mathrm{Q}_{\mathrm{B}} \mathrm{Ci} / \mathrm{m}-\mathrm{sec}}{\pi(1.56) \mathrm{m} / \mathrm{sec}}\left(3.35 \times 10^{-2}\right) \mathrm{m}^{-1} \\
& X=8.9 \times 10^{-16} \mathrm{Q}_{\mathrm{B}^{\prime}} \mathrm{ci} / \mathrm{m}^{3} .
\end{aligned}
$$

Since a person will inhale $20 \mathrm{~m}^{3} / d$, the intake rate, $I_{0^{\prime}}$ is

$$
I_{0}=1.8 \times 10^{-14} \mathrm{Q}_{\mathrm{B}} \mathrm{Ci} / \mathrm{d} \text { or } 1.8 \times 10^{-2} \mathrm{Q}_{\mathrm{B}} \mathrm{pCi} / \mathrm{d} \text {. }
$$

122 
From the AERIN Code, the intake rate, $I_{0}$, of 10- 4 m AMAD particles of ${ }^{239} \mathrm{Pu}$ aerosol for $50 \mathrm{y}$ to give a maximum dose-rate of $5 \mathrm{mrem} / \mathrm{y}$ to the bone is $3.3 \times 10^{-2} \mathrm{pri} / \mathrm{d}$. (The bone receives the highest dose rate and total dose from long-term chronic exposure.)

Equating the two expressions for $\mathrm{I}_{0^{\prime}}$ and solving for $\mathrm{Q}_{\mathrm{B}^{\prime}}$ we obtain:

$$
Q_{B}=\frac{3.3 \times 10^{-2}}{1.8 \times 10^{-2}}=1.8 \mu \mathrm{Ci} / \mathrm{cm}^{3} \text {. }
$$

Table H2 lists values of $Q_{B}$, the concentration of ${ }^{239} \mathrm{Pu}$ in the waste at time of burial, to give $5 \mathrm{mrem} / \mathrm{y}$ at various distances dowmind from the edge of the RCF. A particle size of 50 um AMAD is also shown.

TABLE H2. Values of $Q_{B^{\prime}}$ in $\mu \mathrm{Ci} / \mathrm{cm}^{3}$, that will give a dose rate of $5 \mathrm{mrem} / \mathrm{y}$ to the bone after $50 \mathrm{y}$ of inhalation of contaminated dust.

\begin{tabular}{clc}
\hline Distance downwind & $10 \mu$ MMAD & $50 \mu \mathrm{m}$ AMAD \\
\hline $1 \mathrm{~km}$ & 1.8 & 2.8 \\
$10 \mathrm{~km}$ & $5.2 \times 10^{1}$ & $7.7 \times 10^{1}$ \\
$100 \mathrm{~km}$ & $7 \times 10^{3}$ & $1.0 \times 10^{4}$
\end{tabular}

RECLAMATION SCENARIO

Another potential occurrence we considered is the reclamation of the burial. facility site after institutional control is removed. For this case, workers are considered to be exposed to radioactively contaminated dust while moving earth at the site. The following assumptions are used in the calculations:

- The working atmosphere to which workers are exposed contains $2 \mathrm{mg} / \mathrm{m}^{3}$ of dust.

- The workers spend an average of 1 mo working at the site, and they do not reside there. Consequently, a 176-hr exposure time is used.

- The respiratory rate is $201 / \mathrm{min}$.

- The maximum allowable organ dose is $0.5 \mathrm{rem} / \mathrm{y}$.

- The LLW is assumed to be diluted by a factor of 3 by earth during burial.

- The average interface level concentration is $1 / 10$ the maximum concentration of radioactivity in the wastes at time of burial. 
At a respiration rate of $201 / \mathrm{min}$, a worker will inhale approximately $10 \mathrm{~m}^{3}$ in an $\theta-h r$ work day. At a dust loading of $2 \mathrm{mg} / \mathrm{m}^{3}, 20 \mathrm{mg}$ of contaminated dugt will be inhaled each day.

The dust is contaminated with radioactivity at a concentration $1 / 30$ that of the peak concentration of activity in the waste container when it was buried 100 to $300 \mathrm{y}$ earlier. The amount of radioactivity inhaled by the worker per day, $I_{0^{\prime}}$ in relationship to the concentration in the container at burial given by

$$
I_{0}=\frac{20 E-03 g / d}{p_{s}} \times \frac{Q_{B}}{30}, \mu C i / d,
$$

where

$$
\begin{aligned}
& p_{s}=\text { density of the soil in } \mathrm{g} / \mathrm{cm}^{3} \\
& Q_{B}=\text { concentration in the waste container at burial in } \mu \mathrm{Ci} / \mathrm{cm}^{3} \text {. }
\end{aligned}
$$

Since

$$
\begin{aligned}
& \rho_{s}=2 \mathrm{~g} / \mathrm{cm}^{3} \\
& I_{0}=3.33 \mathrm{E}-04 Q_{B} \mu \mathrm{Ci} / \mathrm{d} .
\end{aligned}
$$

After contact with the soil for 100 or more years, the radioactive nuclides, particularly with heavy alpha emitters, will be firmly attached to the dust particles. Therefore, a reasonably conservative particle AMAD for this contaminated dust would be $10 \mu \mathrm{m}$. We can also assume that the radioactive material would be relatively insoluble in the body.

The AERIN Code was $r$ un for inhalation of ${ }^{239} \mathrm{Pu}$ at a daily intake for $30 \mathrm{~d}$. Particle sizes of $1,5,10$, and 50um AMAD were analyzed.

Table H3 lists the results of these calculations. It shows the value of $I_{0}$ in $\mu \mathrm{Ci}$ inhaled each day for $30 \mathrm{~d}$ that would result in a maximum dose of $0.5 \mathrm{rem} / \mathrm{y}$ for the lung and bone. 
TABLE H3. Calculated inhalation rate, Io in $\mu \mathrm{Cl} / \mathrm{d}$ of ${ }^{239} \mathrm{Pu}$ inhaled for 30 al to give $0.5 \mathrm{rem} / y$ maximum dose to worker at site ("Y" class).

\begin{tabular}{lcccc}
\hline \multirow{2}{*}{ Organ } & \multicolumn{5}{c}{ Particle size (AMAD), $\mu \mathrm{m}$} \\
\cline { 2 - 5 } & 1 & 5 & 10 & 50 \\
Lung & $1.3 \mathrm{E}-04$ & $2.6 \mathrm{E}-04$ & $3.8 \mathrm{E}-04$ & $1.0 \mathrm{E}-03$ \\
Bone & $1.2 \mathrm{E}-03$ & $1.9 \mathrm{E}-03$ & $2.5 \mathrm{E}-03$ & $3.7 \mathrm{E}-03$ \\
\hline
\end{tabular}

In this scenario the lung is the critical organ and, for $0.5 \mathrm{rem} / \mathrm{y}$ exposure, the maximum permissible inhalation rate is $3.8 \mathrm{E}-04 \mathrm{\mu C1} / \mathrm{d}$ for 10um AMAD particles.

From equation (HG) and the calculated value of $I_{0}$ we get

$$
3.33 \mathrm{E}-04 \mathrm{Q}_{\mathrm{B}}=3.8 \mathrm{E}-04
$$

or

$$
\mathrm{Q}_{\mathrm{B}}=1.1 \mu \mathrm{Cl} / \mathrm{cm}^{3}
$$

This quantity is the maximum permissible concentration of ${ }^{239}$ Pu in the waste. Values for other 1sotopes can be found by taking the ratio of their respective MPC in air with ${ }^{239}$ Pu and multiplying by the value of $A_{B}$ above.

Comparing the three scenarios on inhalation, we see that the most restrictive one is that of reclaiming the burial site 100 to $300 \mathrm{y}$ after institutional control is removed.

\footnotetext{
Note that $1.1 \mu \mathrm{C} i / \mathrm{cm}^{3}$ in a waste container will end up averaging approximately $18 \mathrm{nc} / \mathrm{g}$ of soll $\left(\rho=2 \mathrm{~g} / \mathrm{cm}^{3}\right)$. This is comparable to the $10 \mathrm{nci} / \mathrm{g}$ currently used to define TRU waste.
} 


\section{APPENDIX I}

CALCUIATIONS FOR WATERBORNE RELEASES

\section{INTRODUCPION}

Migration of radionuclides from their buriaj site through the geosphere represents an important exposure pathway to the environment. This migration should be considered in any environmental assessment of nucleār waste management alternatives. Several processes influence migration rates and change the rates at which nuclides are released to water systems in the environment. Among them are erosion and suspension of waste partinles in surface water flows, leaching of the buried inventory (the process wherein the nuclide is taken up from its original form and becomes suspended or dissolved in water), and convection (nuclide movement caused by gross water movement). others are dispersion (nuclide movement caused by the nuclide concentration gradient), ion exchange between the nuclides in the water and the matrix through which the water flows, and radioactive decay.

The present analysis does not consider the effect of ingrowth of a particular nuclide from decay of a parent. The effects of radioactive decay have been included to show the decrease in amount of radioactivity with time.

This appendix describes the processes and parameters that we evaluated in this investigation. Also described are a parametric sensitivity analysis and the results of base cases for several nuclides. 


\section{LEACHING MODEL}

Leaching is the process by which buried materials ace dissolved and enter the groundwater. The rate, in $\mathrm{Ci} / \mathrm{y}$, of addition of a nuclide to water is given by:

$$
\frac{d M_{w}}{d t}=M_{I_{0}} \lambda_{l} \exp \left[-\left(\lambda_{l}+\lambda_{d}\right) t\right] \text {. }
$$

where $M_{I}$ is the initial inventory, $\lambda_{\ell}$ is the leach constant, and $\lambda_{d}$ is the decay constant.

The inventory, in $\mathrm{Ci}$, remaining in the burial location at any time is described by :

$$
M_{I}(t)=M_{I_{0}} \text { exf }\left[-\left(\lambda_{l}+\lambda_{d}\right) t\right]
$$

Values of leach rates for the several nuclides considered in this study are obtained using data from drill cores taken in soil below actual LLW disposal sites at INEL. Il We assume that any concentrations of a given nuclide below the pit or pond result from leaching. Thus, by integrating the concentration over the contaminated depth, correcting for radioactive decay, and knowing the burial and sample times, we get an order-of-magnitude estimate for the leach rates.

\section{NUCLIDE MIGRATION}

Nuclide migration is determined from a second-order differential mass-balance equation that considers longitudinal dispersion, convection, sorption, and radioactive decay. Based on a one-dimensional homogeneous medium, this equation describes the concentration as a function of space and time. I2

$$
D \frac{\partial^{2} C}{\partial x^{2}}-v \frac{\partial C}{\partial x}-k \frac{\partial C}{\partial t}-\lambda_{d} C=0 \quad C i / m^{3} Y,
$$


where $C$ is the nuclide concentration, $D$ is the dispersion coefficient, $V$ is the groundwater velocity, and $K$ is the retardation factor. The first term in the equation represents longltudinal dispersion. For conservatism and simplicity. lateral c'speraion has been ignored. The second term represents convection, the third term sorption processes, and the fourth term radioactive decay.

Using Laplace transform techniques on the above equation with boundary conditions chacacterized by a series of unit step functions, the solution is:

$$
C(x, t)=1 / 2 \exp \left(\frac{V x}{2 D}\right)\left[\sum_{j=1}^{N} c_{j} E\left(t-\tau_{j}\right) \mu\left(t-\tau_{j}\right)\right] C i / \pi^{3},
$$

where $N$ is the number of steps in the boundary condition, $\tau_{j}$ is the time at which, the jth step "turns on," $\mu$ is the unit step function, and

$$
\begin{aligned}
f\left(t-\tau_{j}\right)= & \left\{\exp (-a b) \text { erfc }\left[\frac{a-2 b\left(t-\tau_{j}\right)}{2\left(t-\tau_{j}\right)}\right]+\right. \\
& \left.\exp (a b) \text { efrc }\left[\frac{a+2 b\left(t-\tau_{j}\right)}{2\left(t-\tau_{j}\right)}\right]\right\}
\end{aligned}
$$

with

$$
a=\left(\frac{K}{D}\right)^{1 / 2} x
$$

and

$$
\mathrm{b}=\left(\frac{\mathrm{v}^{2}}{4 \mathrm{DK}}+\frac{\lambda \mathrm{d}}{\mathrm{k}}\right)^{1 / 2}
$$

and

$$
\operatorname{erfc}(\theta)=1-\frac{2}{\sqrt{\pi}} \int_{0}^{\theta} e^{-z^{2}} d z
$$

The sorption processes are characterized by the equilibrium sorption coefficient, or time transformation factor, $K^{13}$ which is also expressed as a relative nuclide velocity, i.e., 


$$
K=\frac{v_{\text {water }}}{V_{\text {nuclide }}} \text {. }
$$

Alternately, $K$ is related to the distribution coefficient (the ratio of the concentration of the nuclide in the soil to the concentration of the nuclide in the water) by the equation

$$
K=1+\frac{p}{\varepsilon} K_{d}
$$

where $k_{d}$ is the distribution coefficient, $\rho$ is the soll density, and $\varepsilon$ is soil porosity.

The time of arrival of the contamination front is given approxinately by

$$
t_{\mathrm{a}}=\frac{\mathrm{KL}}{\mathrm{v}_{\text {water }}} y \text {, }
$$

where $L$ is the length of the aquifer.

\section{SOIL AND SITE CHARACTERISTICS}

In this study, the soll has been characterized by the dispersion coefficient, $D$, and the equilibrium sorption coefficient, $K$. The value of $D$ is $0.42 \mathrm{~m}^{2} / \mathrm{y}^{\mathrm{I} 2}$, and the values of $k$ for the various nuclides are shown in Table $I 1$.

TABIE Il. Nuclide-specific parameters and values.

\begin{tabular}{llll}
\hline Nuclide & $\begin{array}{c}\text { Initial } \\
\text { Inventory, Cl }\end{array}$ & $\begin{array}{c}\text { Sorption } \\
\text { coefficient }\end{array}$ & $\begin{array}{c}\text { Leach } \\
\text { rate, y }\end{array}$ \\
\hline${ }^{90} \mathrm{Sr}$ & 24000 & 100 & $1 \times 10^{-2}$ \\
${ }^{129} \mathrm{I}$ & 0.73 & 1 & $1 \times 10^{-2}$ \\
$137 \mathrm{Cs}$ & 35000 & 1000 & $1 \times 10^{-2}$ \\
$237_{\mathrm{Np}}$ & 12000 & 100 & $6 \times 10^{-4}$ \\
$239 \mathrm{Pu}$ & 65000 & 10000 & $6 \times 10^{-4}$ \\
$241 \mathrm{Am}$ & 65000 & 1000 & $6 \times 10^{-4}$ \\
\hline
\end{tabular}

Source: Ref, I5. 
Other parameters characterizing soils have been implicitly assumed in the selection of groundwater velocities. ${ }^{2}$ Included are permeability, porosity, and water pressure gradient.

As has been noted elsewhere, ${ }^{\mathrm{I} 4}$ the information is available about the sorption coefficient for soils. The values of Table Il are for a cypical western desert soil. I5

The parameters representative of the RCF are site area, number of pits, distance from pit bottoms to aquifer, aquifer flow area, aquifer velocity, distance from site to nearest surface waters, and rain rate. Table I2 shows their values.

TABLE I2. Site-specific parameters and values.

Parameter, units value

\begin{tabular}{ll}
\hline Site plan area, $\mathrm{m}^{2}$ & $2 \times 10^{6}$ \\
Number of pits & 100 \\
Distance between pit and aquifer, $\mathrm{m}$ & 10 \\
Water velocity from pit to aquifer, $\mathrm{m} / \mathrm{y}$ & 10 \\
Rain rate, $\mathrm{m} / \mathrm{y}$ & $0.5 \times 10^{-2}$ \\
Aquifer flow area, $\mathrm{m}^{2}$ & 1000 \\
Distance from site to surface water, $\mathrm{m}$ & 1000 \\
Aquifer water velocity, $\mathrm{m} / \mathrm{y}$ & 110 \\
Dispersion coefficient, $\mathrm{m}^{2} / \mathrm{y}$ & 0.42 \\
River volume flow rate at nuclide inlet, $\mathrm{m}^{3} / \mathrm{sec}$ & 2550 \\
River volume flow rate at nuclide outlet, $\mathrm{m}^{3} / \mathrm{sec}$ & 3790
\end{tabular}


Table 13 contains the results of the base case analysis. Strontium-90, ${ }^{137} \mathrm{Cs}$, and the ${ }^{241}$ Am initially present do nut appear at the aquifer outlet, because the initial inventories essentially have decayed completely before they reach the aquifer outlet. The effects of ingrowth of radioactive daughter products may be important, ${ }^{16}$ but they have not been considered. Matching calculations performed by The Analytic Sciences Corp. are also given in Table I3. 
TABLE I3. Preliminary dose calculations.

BASE CASE made]

\begin{tabular}{|c|c|c|c|c|c|c|c|c|}
\hline Isotope & $\begin{array}{c}\text { Burial } \\
\text { Eacility } \\
\text { inventory. } \\
\mathrm{kg}\end{array}$ & $\begin{array}{c}\text { Burial } \\
\text { facility } \\
\text { inventory, } \\
\text { Ci }\end{array}$ & $\begin{array}{l}\text { Average } \\
\text { burial } \\
\text { facility } \\
\text { activity, } \\
\mathrm{Ci} / \mathrm{m}^{3}\end{array}$ & $\begin{array}{l}\text { Arrival rime } \\
\text { of contamina- } \\
\text { tion front, } \\
y \text { (half-lives) }\end{array}$ & $\begin{array}{l}\text { Peak Fraction } \\
\text { of or Iginal } \\
\text { inventory } \\
\text { released to } \\
\text { river, } y^{-1}\end{array}$ & $\begin{array}{l}\text { Activity into } \\
\text { river per year } \\
\text { after arrival } \\
\text { of contanination } \\
\text { front, } \mathrm{Ci} / \mathrm{y}\end{array}$ & $\begin{array}{l}\text { Average } \\
\text { individual } \\
50-y \text { body } \\
\text { dose, reo }\end{array}$ & $\begin{array}{l}\text { Total } \\
\text { popula- } \\
\text { tion } \\
\text { dose, } \\
\text { man-ree } \\
50 \mathrm{y}\end{array}$ \\
\hline${ }^{239} \mathrm{Pu}$ & 1060 & $6.5 \times 10^{4}$ & 0.11 & $10^{5}$ (4.1) & $2.0 \times 10^{-7}$ & $1.3 \times 10^{-2}$ & $1.2 \times 10^{-7}$ & $0.9 \times 10^{-2}$ \\
\hline${ }^{241} \mathrm{Am}$ & 1995 & $6.5 \times 10^{6}$ & 11.0 & $10^{5}$ (22) & -- & - & $\cdots$ & -- \\
\hline $237 \mathrm{~Np}$ & $1.72 \times 10^{4}$ & $1.2 \times 10^{4}$ & $2.1 \times 10^{-2}$ & $10^{3}\left(4.7 \times 10^{-4}\right)$ & $6.0 \times 10^{-6}$ & $7.2 \times 10^{-2}$ & $1.1 \times 10^{-6}$ & $8.8 \times 10^{-1}$ \\
\hline${ }^{129} 9_{I}$ & 4.2 & 0.73 & $1.3 \times 10^{-6}$ & $10^{1}\left(6.3 \times 10^{-7}\right)$ & $9.0 \times 10^{-3}$ & $6.6 \times 10^{-3}$ & $9.9 \times 10^{-8}$ & $7.9 \times 10^{-2}$ \\
\hline${ }^{137} \mathrm{Cs}$ & 40 & $3.5 \times 10^{6}$ & 6.2 & $10^{4}(34)$ & -- & -- & - & -- \\
\hline${ }^{90} \mathrm{sr}$ & 17 & $2,4 \times 10^{6}$ & 4.2 & $10^{3}$ (35) & -- & -- & -- & -- \\
\hline
\end{tabular}

TASC model

\begin{tabular}{lllllllll}
239 & & & \\
& 1060 & $6.5 \times 10^{4}$ & 0.11 & $1.3 \times 10^{5}(5.3)$ & $1.8 \times 10^{-8}$ & $1.1 \times 10^{-3}$ & $1.0 \times 10^{-8}$ & $8.0 \times 10^{-3}$ \\
237 Np & $1.72 \times 10^{4}$ & $1.2 \times 10^{4}$ & $2.1 \times 10^{-2}$ & $10^{3}\left(4.7 \times 10^{-4}\right)$ & $6 \times 10^{-6}$ & $7.2 \times 10^{-2}$ & $1.1 \times 10^{-6}$ & $8.8 \times 10^{-1}$ \\
129 & 4.2 & 0.73 & $1.3 \times 10^{-6}$ & $17\left(1.1 \times 10^{-6}\right)$ & $10^{-2}$ & $7.3 \times 10^{-3}$ & $1.1 \times 10^{-7}$ & $8.8 \times 10^{-2}$ \\
\hline
\end{tabular}


EROSION

It is conservative to assume that future confinement facilities will not be sited in areas wherr substantial erosion is likely to occur. Nontheless, some contamination world ultimately be released to surface waters or dispersed into the atmosphere if the RCF were located in an area where wind or water erosion were occurring. Design features, such as covering the filled burial area with pebbles through which grass vegetation could be established, would tend to minimize erosion processes.

To determine whether erosion may pose a substantial health $r$ isk, we performed a simplistic yet conservative calculation based on a representative erosion rate. A number of site-specific parameters influence erosion rates. Among them are surface slope, amount of precipitation, distances to watercourses, distances from peaks, amount and type of vegetation, and soil properties. A typical sheet erosion rate is 6 tons of soil per acre per year. I7 Using this rate, the RCF pit surface area of 50 acres, and a soil density of $2 \mathrm{~g} / \mathrm{cm}^{3}$, one determines that 1500 y are needed for a surface covered $1 \mathrm{~m}$ thick to be eroded away before erosion of the buried wastes begins. The concentration in the eroded material that will give guideline doses to maximum individuals and populations can be determined if three assumptions are made: (I) a dilution factor of 3 accounts for the mixing of the wastes with soil during burial, (2) a factor of 10 accounts for the difference between the interface and average concentrations of activity in the waste, and (3) dilution and holdup of eroded material between the pits and the river are ignored.

If all of the eroded material goes directly into the river (with a volumetric flow rate of $2550 \mathrm{~m}^{3} / \mathrm{sec}$ ), and if sedimentation is neglected, it would take an initial waste concentraition of $10^{5} \mu \mathrm{Ci} / \mathrm{cm}^{3}$ of ${ }^{239} \mathrm{Pu}$ to give a maximum individual dose of $0.5 \mathrm{rem} / \mathrm{y}$. This calculation presumes that the erosion takes place uniformly over the total surface and that gullying and preferential erosion do not occur. For the erosion case, where potentially large populations may be involved, guideline doses of $5 \mathrm{mrem} / \mathrm{Y}$ to maximum individuals may be more appropriate. This would allow concentrations of ${ }^{239} \mathrm{pu}$ in the wastes of $1000 \mu \mathrm{Ci} / \mathrm{cm}^{3}$. 
It is evident that, even with overly conservative assumptions, erosion does not give the most restrictive limitation of concentration. Factors such as establishment of a dense vegetative cover over the buried wastes and siting the containment facility where sheet erosion does not occur would reduce even further any possible consequences of erosion.

\section{PARAMETRIC VARIATIONS}

Figure Il shows the effect of variation of the leach constant, $\lambda_{\ell}$, hence the leach rate, $\frac{d M}{d t}$, on the concentration at the pit bottom. As the value of the leach rate decreases significantly below the decay rate, the decay rate beccmes more dominant in determining the rate at which the concentration changes. The converse is also true. Figure Il demonstrates also that the concentration increases as the leach rate increases.

The influence of the dispersion coefficient, $D$, on the response at the aquifer outlet is shown in Fig. I2. As the dispersion of the pulse increases (i.e.. as the dispersion coefficient increases), the pulse becomes broader and is reduced in magnitude.

Figure I3 shows that, as the hypothetical pulse boundary condition is decreased in duration (but not in magnitude) with a constant dispersion coefficient, the magnitude of the concentration at the aquifer outlet is accordingly decreased. That is, as the pulse is shortened, the output has less time to equilibrate, and it achieves a smaller fraction of equilibrium concentration.

Figure I4 shows the effect on individual doses of varying the volunetric flow rate of the stream into which the wastes flow. This study used a base case of a rather large flow typical of the columbia River. As long as the relative uses of water along the stream remain constant, the population doses do not depend we the specific volumetric flow rate. 


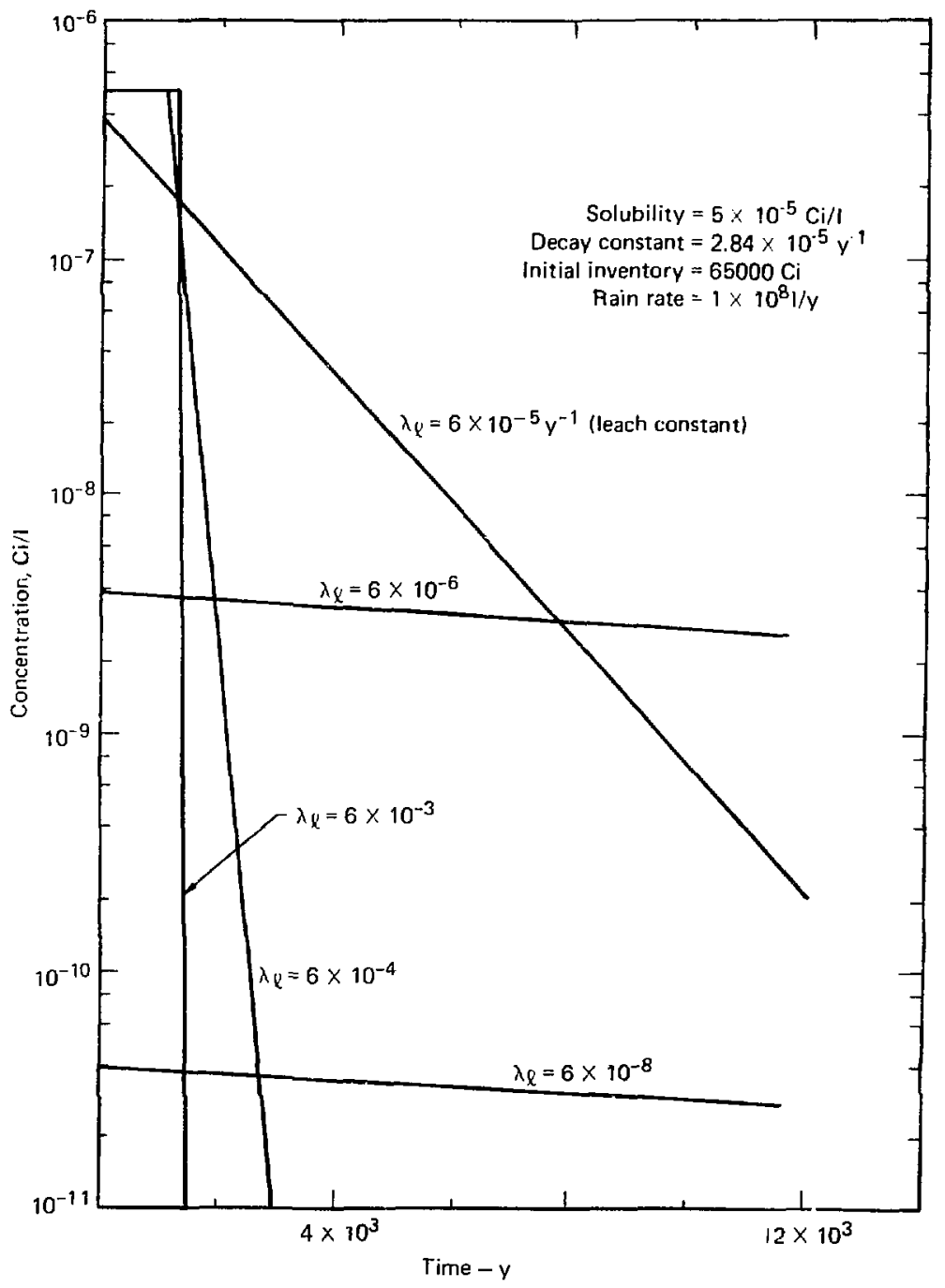

FIG. Il. Concentration at pit bottom for ${ }^{239} \mathrm{Pu}$ vs time, with leach constant as a parameter. 


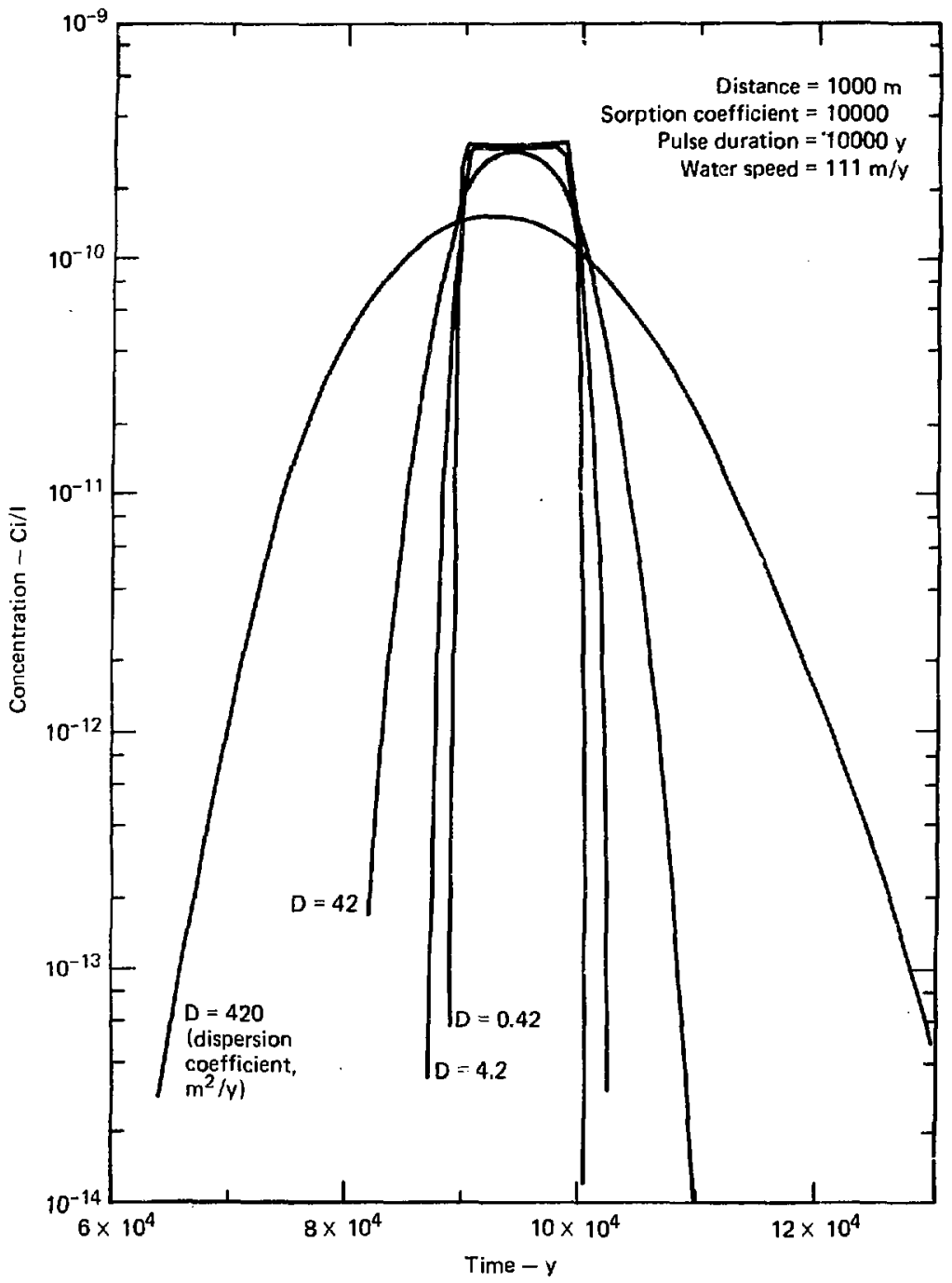

FIG. I2. Concentration at aguifer outlet vs time with dispersion coefficient as a parameter for ${ }^{239} \mathrm{Pu}$. 


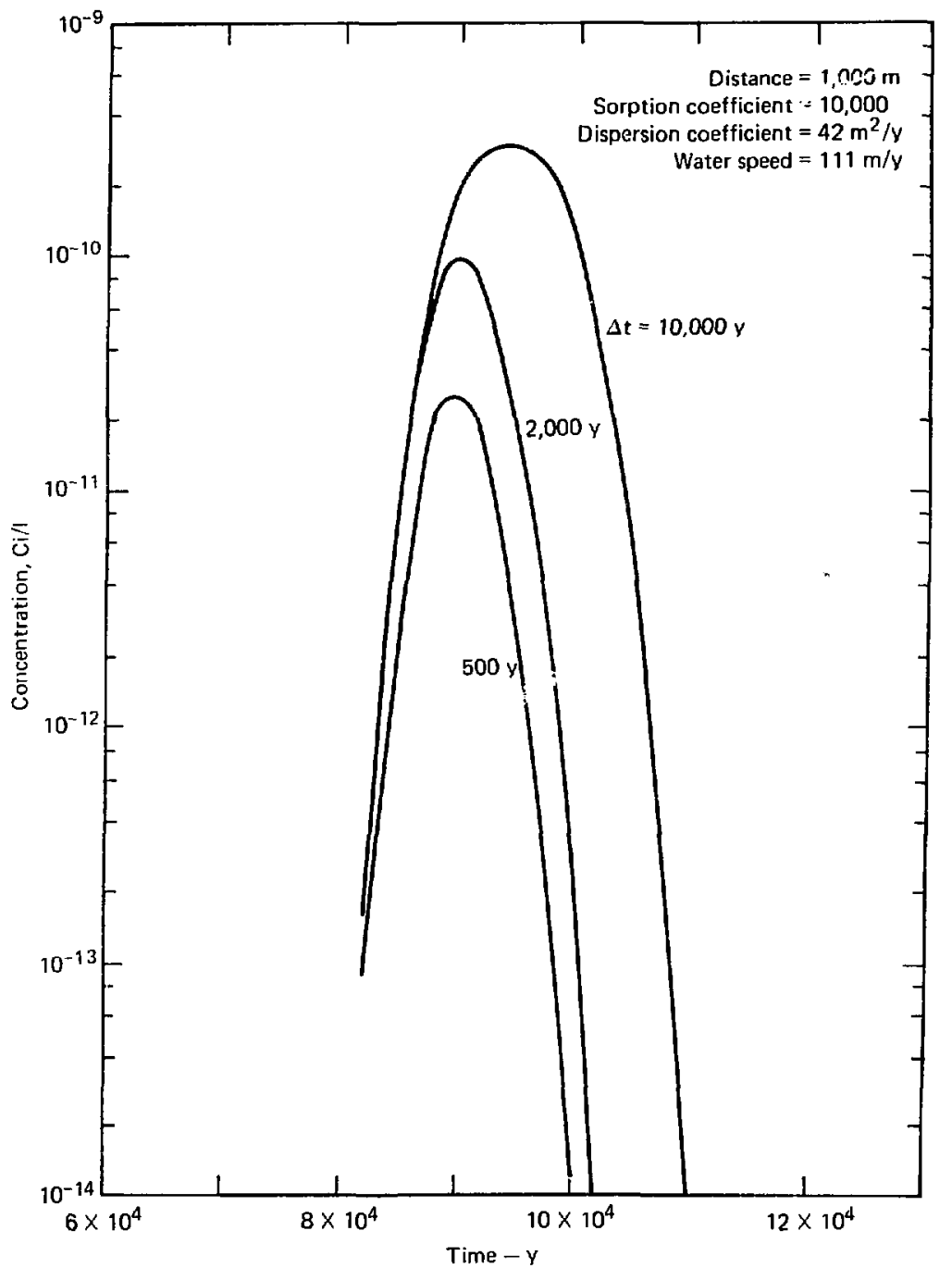

FIG. 13. Concentration at aquifer outlet vs time for ${ }^{239} \mathrm{Pu}$ with boundary condition pulse length as a parameter. 


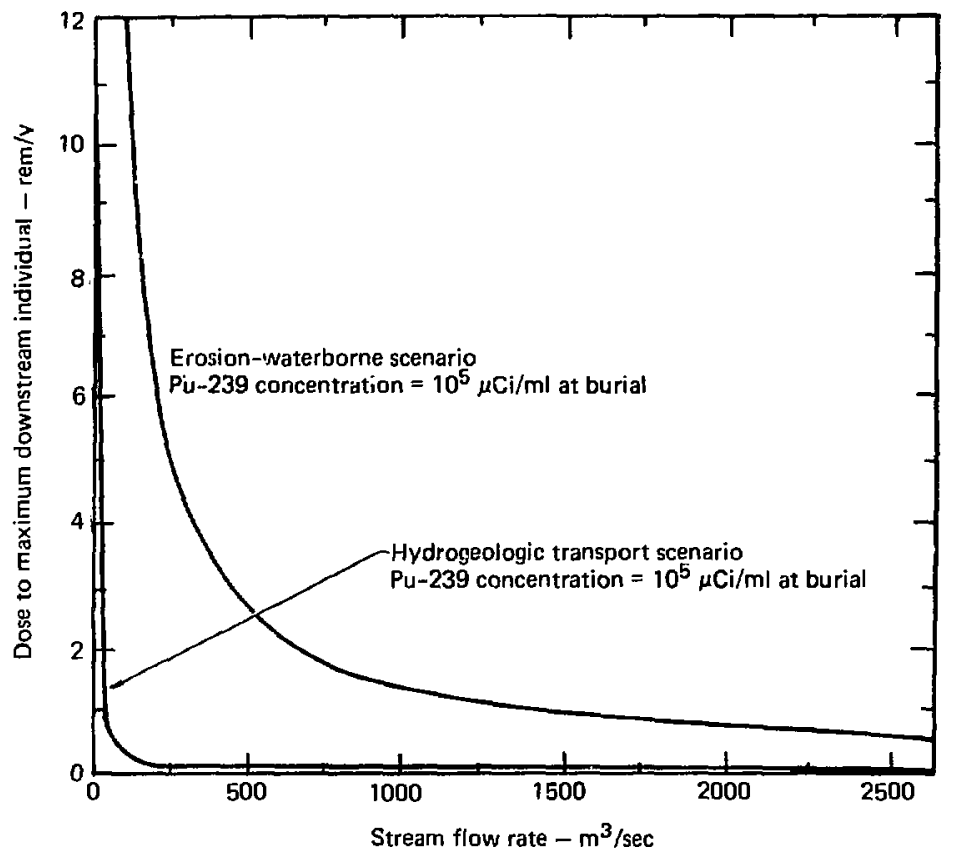

FIG. I4. Effects of water volumetric flow rate in stream on maximum individual doses. 


\section{DRILLED WELL SCENARIO}

In this scenario, we assume that institutional control of the waste burlal site is removed $100 \mathrm{y}$ after burial operations have ceaged. A well is drilled some time later into the aquifer under the RCF, and individuals then drink the water continually for $50 \mathrm{Y}$. The guestion then is: what concentration of ${ }^{239} \mathrm{Pu}$ could be allowed in the burier waste such that persons drinking the contaminated water at the maximum concentration continually for 50 yould accumulate just enough ${ }^{239} \mathrm{Pu}$ in the body to produce an internal dose of 0.5 rem/y?

Based on the work of Isaacson et al. ${ }^{\text {IB }}$ on the trangport of soil moisture, it is unlikely that any radionuclides will reach the aquifer if the radioactive burial site is properly located in an arld region. We shall assume for this scenario, however, that water percolates slowly from the ourface through the buried waste into the aquifer. The transport processes include leaching of the material from the site of burial and downward movement through the soil, where the nuclide is sorbed and desorbed, reaching the aquifer where the concentration increases to a maximum depending on the varlous parameters used in the transport equation.

The following assumptions are used in the calculations:

- Average annual rainfall is $0.1 \mathrm{~m} / \mathrm{y}$.

- The fraction of precipitation that percolates through the buried waste 1s 0.001 . The remainder goes to surface runoff, evaporation, and plant evapotranspiration. I8

- The surface area of the RCF is $1.2 \times 10^{6} \mathrm{~m}^{2}$.

- The volume of the waste burial pits is $6 \times 10^{5} \mathrm{~m}^{3}$.

- The dilution factor of the waste with the soil is 3 .

- The average concentration of the waste at burial is $1 / 10$ of the peak concentration limit imposed.

- The depth of the adsorbing medium between the waste and the aquifer is $10 \mathrm{~m}$.

- The average static volume of the aquifer directly under the RCF is $10^{7} \mathrm{~m}^{3}$. 
- The annual fJuw of water in the aquifer entering the region directly under the RCF from adjacent areas is $\mathrm{J} .2 \times 10^{6} \mathrm{~m}^{3} / \mathrm{y}$ (based on a flow rate of $100 \mathrm{~m} / \mathrm{y}$ and a cross sectional area of the aquifer of $10^{4} \mathrm{~m}^{2}$ ).

- Due to the effects of temperature, evaporation, and capillary action, the net effective downward transport velocity of the moisture is $1 / 3 \mathrm{~m} / \mathrm{y}$.

Since we are interested in finding only the maximum concentration of the nuclide in the aquifer, we shall ignore the effects of dispersion and convection as the nuclide passes through the adsorbing soil. This approach reduces the calculating effort, but it overestimates the value of the maximum concentration. The error introduced is on the conservative side, however.

The adsorhing medium slows up or delays the trarsport of the nuclide through the medium. As shown previously, the transit time for any given molecule of the nuclide through the medium is given by

$$
t_{a}=\frac{k L}{V_{w}},
$$

where

$$
K=1 .+\frac{\rho}{E} K_{d},
$$

and

$$
\begin{aligned}
L & =\text { thickness of the adsorbing mediun } \\
V_{W} & =\text { average net transport velocity of the water through the medium } \\
\rho & =\text { aensity of the medium } \\
\epsilon & =\text { porosity } \\
\mathrm{R}_{d} & =\text { distribution coefficient. }
\end{aligned}
$$


Eventually all the nuclides will pass through the adsorbing medium into the aquifer except for what is lost by radioactive decay during the delayed transit time. Since we have ignored the effects of dispersion and convection, the rate of flow of the nuclide into the aquifer will be equal to the rate of Elow of the nuclide into the adsorbing medium, except that radioactive decay during the delay will appropriately reduce the guantity.

We shal.l assume a two-compartment model, with a delay line between the two, to describe the transport between the burial pits and the aguifer. If we let $Q_{\mathrm{A}}$ be the quantity, in $\mathrm{Ci}$, of any radionuclide in the aquifer at any time $t$, the rate of change in $g_{A}$ per unit time is given by the equation

$$
\frac{d Q_{A}}{d t}=\lambda_{\ell} Q_{g} \exp -\left(\lambda+\lambda_{\ell}\right) t \exp \left(-\lambda t_{a}\right)-(\lambda+\mu) Q_{A},
$$

where

$$
\begin{aligned}
& \lambda_{\ell}=\text { leach constant (fraction } / Y \text { ) } \\
& \lambda=\text { adioactive decay constant }\left(y^{-1}\right) \\
& \mu=\text { turnover } r \text { ate in the aquifer resulting from inflowing water }\left(y^{-1}\right) \\
& \mu=\left(\frac{f_{r}+f_{a}}{v_{s}}\right) \\
& f_{r}=\text { fraction of precipitation entering tine aguifer }\left(\mathrm{m}^{3} / \mathrm{y}\right) \\
& f_{a}=\text { aquifer flow Erom adjacent area }\left(\mathrm{m}^{3} / y\right) \\
& v_{s}=\text { static volume of the aquifer }\left(\mathrm{m}^{3}\right) \\
& t_{a}=\frac{K L}{V_{w}} \\
& \begin{array}{l}
Q_{B_{0}}=\text { total quantity, in } C i \text {, of the nuclide in the burial } \\
\text { ground at } t=0 \text {. }
\end{array}
\end{aligned}
$$

Substituting the value of $t_{a}$ and applying the boundary condition that $Q_{A}=0$ at $t=0$, the solution of the differential equation is 


$$
Q_{A}=\frac{\lambda_{\ell} Q_{B_{0}} e^{-\lambda \frac{K L}{V_{w}}}}{\mu-\lambda_{l}}\left[e^{-\left(\lambda+\lambda_{\ell}\right) t}-e^{-(\lambda+\mu) t}\right] .
$$

One must remember that $Q_{A}$, as given 1 n the above equation, is the quantity of the radionuclide in the aquiter at a time $t+\frac{K L}{V_{W}}$. For any given molecule contalning the radioactive atoms entering the adsorbing mesium from the burial pit, a delay of $\frac{K L}{V_{w}}$ y occurs before that molecule moves into the aquifer.

After the delay time, the value of $Q_{A}$ will increase to a maximum some time later depending on the parameters used in the equation. Figure I5 is a plot of $Q_{A} / Q_{B}$ vs time after arrival of ${ }^{239} \mathrm{Pu}$ at the aquifer. In the scenario we used, one sees that the quantity of ${ }^{239} \mathrm{Pu}$ in the aquifer attains its maximum about $45 \mathrm{y}$ after the ${ }^{239}$ pu first reaches the layer.

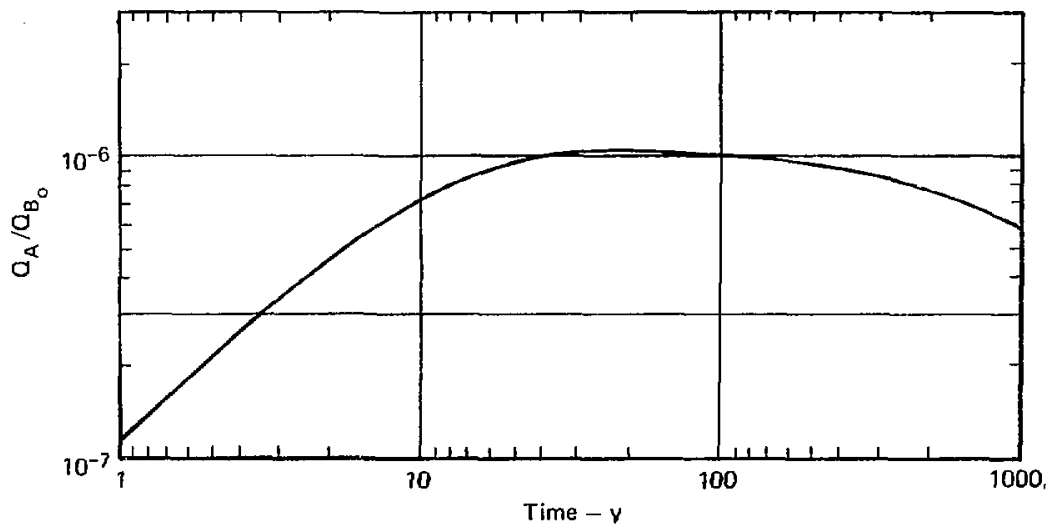

FIG. I5. $Q_{A} / Q_{B}$ vs time for ${ }^{239} \mathrm{Fu}$. 
The concentration of the radionuclide in the well water equals the concentration in the aguifer. It is given by

$$
c_{A}=\frac{Q_{A}}{v_{S}}
$$

If we now set $C_{A}$ equal to the $M P C_{W}$ (maximum permissible concentration in water) that will result in a dose equivalent of $0.5 \mathrm{rem} / \mathrm{y}$ after people have been drinking such water for $50 y$ and solve for $Q_{B_{0}}$, we get the amount or total inventory of the specific nuclide that can be permitted in the burial ground.

Equation Il can be solved for the ratio $Q_{A} / Q_{B_{O}}$. Since

$$
\mathrm{Q}_{\mathrm{A}}=\frac{\mathrm{Q}_{\mathrm{A}}}{\mathrm{Q}_{\mathrm{B}_{\mathrm{O}}}} \times \mathrm{Q}_{\mathrm{B}_{\mathrm{O}}},
$$

and since we want to set $M P C_{w}=C_{A}$, we can solve for $Q_{B_{O}}$ as follows:

$$
\mathrm{Q}_{B_{0}}=\frac{M \mathrm{MC}_{w} \times v_{\mathrm{s}}}{\left(\mathrm{Q}_{\mathrm{A}} / \mathrm{Q}_{\mathrm{B}_{0}}\right)^{\prime}},
$$

The peak concentration, $c_{c^{\prime}}$ permitted in the waste container at the time of burial is given by

$$
c_{c}=\frac{Q_{B_{O}}}{v_{b}} \times 30,
$$

or

$$
c_{c}=\frac{M P C_{w} \times v_{s} \times 30}{\left(Q_{A} / Q_{B_{0}}\right) \times v_{b}}
$$

where $v_{b}=$ original volume of the buried waste (assumed to be $6 \times 10^{5} \mathrm{~m}^{3}$ ). 
With the previous assumptions, we substituted the following values in Eq. (IIO) and Eq. (II4) to get the value of $C_{c}$ for the ${ }^{239} \mathrm{pu}$ :

$$
\begin{aligned}
& \lambda=2.84 \times 10^{-5} y^{-1} \\
& M P C_{w}=1.7 \times 10^{-6} \mathrm{ci} / \mathrm{m}^{3} \\
& \lambda_{\ell}=6 \times 10^{-4} y^{-1} \\
& v_{s}=1 \times 10^{7} \mathrm{~m}^{3} \\
& \lambda+\lambda_{\ell}=6.3 \times 10^{-4} \mathrm{y}^{-1} \\
& v_{b}=6 \times 10^{5} \mathrm{~m}^{3} \\
& K=1 \times 10^{4} \\
& \mu+\lambda=1.3 \times 10^{-1} y^{-1} \\
& \mu=1.1 \times 10^{-1} \mathrm{y}^{-1} \\
& \exp \left(-\lambda \frac{K L}{v_{w}}\right)=1.99 \times 10^{-4} \\
& \lambda_{\ell} /\left(\mu-\lambda_{\ell}\right)=5.4 \times 10^{-3}
\end{aligned}
$$

With these values, we calculate $Q_{A} / Q_{B_{0}}=1.04 \times 10^{-6}$, which is the maximun value occurring 45 y after first arrival in the aquifer. Therefore, we see that the concentration, $C_{c}$, of ${ }^{239} \mathrm{Pu}$ permitted in the waste container at the time of burial is $820 \mu \mathrm{ci} / \mathrm{cm}^{3}$ in the well-water scenario, using the parameters we have assuned. The most critical parameter in the equations is the value of $v_{w}$, the net average velocity of the water ir. the soil. As mentioned previously, the work of Isaacson et al. ${ }^{8}$ would indicate that the value of $v_{w}$ is equal to or very near zero for an arid region when the site is properly located. If so, the radioactive nuclides would never reach the level of the aquifer. 


\section{REFERENCES}

I1. B. L. Schmalz, Radionuclide Distribution in Soil Mantle of the Lithosphere as a Consequence of Waste Disposal at the National Reactor Testing Station, U.S. Atomic Energy Commission, Idaho Operations office, Report IDO-10049 (Octoher 1972).

I2. D. H. Lester, G. Jansen, and H. C. Burkholder, Migration of Radionuclide Chains Through An Absorbing Kedium, Battelle Paciflc Northwest Laboratories, Richland, Wash., Report BNWL-SA-5079 (December 1974).

13. Y. Inoue and S. Morisawa, "On the Selection of a Ground Disposal Site for Radioactive wastes: An Approach To Its Safety Evaluation," Health Physics, 26, 53-63 (1974).

14. D. D. Huff and P. Rruger, "simulation of the Hydrologic Transport of Radioactive Aerosols," Ch. 27 of Radionuclides in the Environment, Advances in Chemistry Series 93 (American Chemical Socie.., Washington, D.C., 1970).

I5. H. C. Burkholder et al., Incentives for Partitioning High-Level Waste, November 1975, Battelle Pacific Northwest Laboratories, Richland, Wash., BNWL-1927, UC-70 (November 1975).

I6. H. C. Burkholder, "Methods and Data for Predicting Nuclide Migration in Geologic Media," Proceedings of the International Symposium on Managenent of Wastes from the LWR Fuel Cycle, CONF-76-0701, Denver, Colo. \{July 11-16, 1976).

I7. D. D. Smith and W. H. Wischmeier, "Factors Affecting Sheet and Rill Erosion," Trans., American Geophysical Union (December 1957).

I8. R. E. Isaacson, I. E. Brownell, R. W. Nelson, and E. L. Roetman, Soil Moisture Transport in Ar1d Site Vadare Zones, ARH-SA-169 (January 1974). 
APPENDIX $\mathbf{J}$

APPLICATION OF THE RELATIVE HAZARD INDEX (RHI)

CONCEPT FOR INDIVIDUAL NUCLIDES AND MIXTURES

Let $c_{1}, c_{2}, c_{3}, \ldots, c_{n}=$ the concentration of various nuclides in the waste. For a single nuclide, we have by definition

$$
\mathrm{RHI}=\frac{\mathrm{C} \mathbf{K}}{\mathrm{MPC}_{\mathrm{a}}},
$$

where

$$
\begin{aligned}
C & =\text { concentration in } \mu \mathrm{Ci} / \mathrm{ml} \\
\mathbf{K} & =\frac{\text { dust loading }}{\text { soil density }} \\
\mathrm{MPC}_{\mathbf{a}} & =\text { maximum permissible concentration in air } .
\end{aligned}
$$

For any mixture of nuclides, the total hazard index is given by the sum of the individual RHIs for each nuclide; that is,

$$
(\mathrm{RHI})_{\mathrm{T}}=(\mathrm{RHI})_{1}+(\mathrm{RHI})_{2}+(\mathrm{RHI})_{3}+\ldots(\mathrm{RHI})_{\mathrm{n}}
$$

The (RHI) ${ }_{T}$ must not exceed the interface value of $1.7 \times 10^{4}$ as shown in Fig. 9. (An activity-weighted average half-life could be used to increase th: acceptable total RHI. If the average half-life cannot be reasonably e.tablished, one should assume that it is long enough to give $1.7 \times 10^{4}$ for the total RHI.) Rewriting the above equation,

$$
(\mathrm{RHI})_{\mathrm{T}}=\frac{\mathrm{C}_{1} \mathrm{~K}}{\mathrm{MPC_{1 }}}+\frac{\mathrm{c}_{2} \mathrm{~K}}{\mathrm{MPC}_{2}}+\frac{\mathrm{c}_{3} \mathrm{~K}}{\mathrm{MPC_{3 }}}+\frac{\mathrm{c}_{\mathrm{n}} \mathrm{K}}{\mathrm{MPC_{n }}} \cdots
$$


The interface concentration, here designated by $C_{I^{\prime}}$ is found by solving for $C$ when given $K$ and $\mathrm{RHI}_{\mathrm{T}}$.

$$
C_{I}=\frac{R H I_{T} M F C_{a}}{K}
$$

Rearranging terms in Eq. (Jl) yields

$$
\frac{c_{1} K}{M_{1} \mathrm{RHI}_{T}}+\frac{c_{2} K}{\mathrm{MPC}_{2} \mathrm{RHI}_{T}}+\frac{c_{3} K}{\mathrm{MPC}_{3} \mathrm{RHI}_{T}}+\cdots \frac{c_{n} K}{\mathrm{MPC}_{n} R H I_{T}}=1
$$

Substituting Eq. (J2) into Eg. (J3) gives

$$
\frac{c_{1}}{c_{I 1}}+\frac{c_{2}}{c_{I 2}}+\frac{c_{3}}{c_{I 3}}+\cdots \frac{c_{n}}{c_{I n}}=1 .
$$

Therefore, if the sum of the left-hand side of Eq. (J4) is $\leq 1$, the material may be considered low-level waste. For example, if the waste contains the following mixture of nuclides,

$$
\begin{array}{ccc}
{ }^{90} \mathrm{Sr} & 2.3 \times 10^{2} & \mu \mathrm{Ci} / \mathrm{ml} \\
{ }^{90} \mathrm{Y} & 2.3 \times 10^{2} & \mu \mathrm{Ci} / \mathrm{ml} \\
{ }^{137} \mathrm{Cs} & 8.8 \times 10^{3} & \mu \mathrm{Ci} / \mathrm{ml} \\
{ }^{239} \mathrm{Pu} & 4.2 \times 10^{-1} & \mu \mathrm{Ci} / \mathrm{ml}
\end{array}
$$

is the material low-level waste?

Using Eq. 36 with the values of $C_{I}$ calculated from values in Taible 9 yields:

$$
\frac{2.3 \times 10^{2}}{2 \times 10^{3}}+\frac{2.3 \times 10^{2}}{2 \times 10^{5}}+\frac{8.8 \times 10^{3}}{4 \times 10^{4}}+\frac{4.2 \times 10^{-1}}{1.0}=y .
$$

$y=0.76$, which is less than 1 . The answer to the above question is yes; the material is low-level waste. 